\title{
MIRÓBRIGA: SUA VALORIZAÇÃO E CARACTERIZAÇÃO
}

\author{
Maria Filomena SANTOS BARATA
}

\section{Resumo}

O Sítio Arqueológico de Miróbriga, classificado como Imóvel de Interesse Público desde 1940, afecto ao Instituto Português do Património Arquitectónico desde 1982, situa-se no Sudoeste alentejano, nas proximidades da cidade de Santiago de Cacém, sede de concelho com o mesmo nome.

Miróbriga foi habitada desde, pelo menos, a Idade do Ferro, quando a zona de cumeada é ocupada por povos de possível raiz céltica, como se pode deduzir pelo topónimo terminado em «briga». A partir de, pelo menos, o século II a.C. Miróbriga entra na esfera de influência romana, e no século I d.C. foi implementado um programa de amplas construções, tendo-se estendido o aglomerado urbano também para as zonas mais baixas.

Interpretado como um Santuário por alguns investigadores, Miróbriga trata-se de um aglomerado urbano com as características comuns a cidades provinciais do Império.

Na zona mais elevada e sobrepondo-se à ocupação anterior, foi edificado um forum com um templo centralizado, consagrado ao culto imperial, e um outro templo possivelmente dedicado a Vénus. Essa praça pública é ladeada de construções que se deverão tratar das edificações comuns aos fora provinciais, tais como a cúria e a basílica.

A Sul e Oeste da praça pública desenvolve-se uma zona comercial, constituída por várias tabernae que fazem como que cinturas ou «anéis» em relação ao centro da cidade, sendo conhecidas algumas das calçadas dessas «circunvalações».

As termas de Miróbriga, uma das melhor conservadas em território português, são compostas por dois edifícios, provavelmente dedicados cada um deles a homens e a mulheres.

As zonas habitacionais são ainda mal conhecidas. São, no entanto, visíveis algumas insulae ao longo das calçadas que atravessam o aglomerado urbano. 
Afastado do centro situava-se um hipódromo, o único conhecido em território actualmente português, onde se realizavam os espectáculos hípicos.

\section{Resumé}

Le site archéologique de Miróbriga, classé Immeuble d'Intérêt Publique, depuis 1940, affecté à l'Institut Portugais du Patrimoine Architecturale (IPPAR), depuis 1982, se situe dans le Sud-Ouest d'Aaalentejeo, près de la ville de Santiago do Cacém, siège de la commune du même nom.

Miróbriga a été habitée depuis, au moins, l’Âge du Fer, quand la zone du sommet a été occupée par des peuples, probablement, d'origine celtique, comme il est possible de déduire par le toponyme «Briga».

À partir, au moins, le siècle $2^{\text {éme }}$ avant J.C., Miróbriga entre dans al sfère d'influence Romaine et dans le siècle $1^{\text {er }}$ après J.C., il a été entre pris un programme de grandes constructions, s'ayant, l'agglomérat urbain, aussi étendu vers les zones les plus basses.

Identifié, par quelques chercheurs, comme étant un sanctuaire, Miróbriga s'agit d'un agglomérat urbain avec les caractéristiques communes aux villes provincielles de l'Empire.

Dans la zone la plus haute, se superposant à une antérieure occupation, a été bâtit un forum avec un temple au centre, consacré au culte impérial et un autre temple, probablement dédiée à Venus. Cette place publique a été entourée par des constructions qui étaient, probablement, des immeubles connus aux «fora» provinciaux, comme, par exemple la curie et la basilique.

À Sud et Ouest de la place publique se développe une zone commerciale, constituée par plusieus tabernae qui font comme des ceintures, ou "anneaux" par rapport au centre de l'urbs, ayant été identifiées quelques unes des chaussées de ces «circunvalations».

Les thèrmes de Miróbriga, une des mieux conservées en territoire portugais, sont composées par deux édificies, probablement réservés un à des hommes et l'autre à des femmes.

Les zones habitationelles sont encore mal connues. Cependant, quelques insulae sont visibles, tout au long des chaussées qui traversent l'agglomérat urbain.

Éloigné du centre se situait un hypodrome, le seul connu, pour le moment, en territoire portugais, oú se réalisait les spectacles hypiques. 
O Sítio Arqueológico de Miróbriga, classificado como Imóvel de Interesse Público desde 1940, é afecto ao Instituto Português do Património Arquitectónico (IPPAR).

Referenciado desde o século XVI por André de Resende que, retomando as referências de Plínio, se referiu a uma povoação outrora chamada Merobrica, no seu De Antiquitatibus Lusitaniae, este humanista deixou-nos memória da existência de vestígios de muralhas cercadas de torres, de um aqueduto, de uma ponte e de uma fonte, que o fizeram concluir que, no local, tinha havido uma "antiga cidade". Resende estudou algumas inscrições provenientes de Miróbriga, algumas das quais posteriormente consideradas falsas ou fruto da imaginação do estudioso humanista.

Miróbriga tem sido objecto de várias campanhas de escavação desde o século XIX, promovidas por D. Frei Manuel do Cenáculo, e de inúmeros trabalhos arqueológicos durante a presente centúria, entre as quais as dirigidas por D. Fernando de Almeida nos anos 60 e 70.

Na primeira parte da década de oitenta, foram também efectuadas várias campanhas de escavação por uma equipa luso-americana, tendo sido os trabalhos aí efectuados objecto de uma publicação detalhada - Mirobriga, BAR International Series 451, Oxford.

Desde 1990 que o IPPAR vem desenvolvendo um «Programa de Valorização» (BARATA, 1990: 61-67) ${ }^{1}$, que implicou fazer um levantamento das prioridades, numa primeira fase, e, periodicamente, "Planos de Acção"2 para Miróbriga.

Este Sítio Arqueológico foi, posteriormente, inscrito num programa de acções estruturantes "Itinerários Arqueológicos do Alentejo e do Algarve", ao abrigo de um acordo assinado, em 1994, entre a então Secretaria de Estado da Cultura, através do IPPAR, e a Secretaria de Estado do Turismo, através do Fundo de Turismo. Visando igualmente estipular a colaboração num conjunto de acções que têm em vista a preservação de Miróbriga, foi recentemente assinado um acordo entre o IPPAR e a Câmara Municipal de Santiago do Cacém. Nesse contexto têm vindo a desenvolverse anualmente um conjunto de acções que se prendem com o conhecimento, conservação, manutenção e valorização do Sítio Arqueológico ${ }^{3}$.

' Por «Valorização» entendemos um conjunto de acções que têm em vista salientar e importância cultural de um Sitio Arqueológico e contribuir, paralelamente, para o seu conhecimiento, preservação, divulgação e fruição pública.

${ }^{2}$ Segundo os conceitos usados por CARRERA, 1993: 103 a 106.

${ }^{3}$ Durante o ano de 1997, realizaram-se várias acções que tiveram como objectivos:

- A edição de vários materiais de divulgação - um desdobrável e postais;

- A conservação e restauro de algumas estruturas arqueológicas das termas e área habitacional; 
Ainda durante o ano de 1999, está previsto dar início à construção do "Centro Interpretativo e de Acolhimento", que tem em vista apoiar os trabalhos arqueológicos, acolher o público visitante, realizar uma exposição dedicada a Miróbriga e ao seu território em período romano e organizar mostras temporárias e ciclos de conferências temáticos.

O novo edifício deverá situar-se num decline fronteiro à cidade romana, permitindo o local escolhido para a sua implantação a visibilidade de praticamente todo o aglomerado antigo.

A futura entrada em Miróbriga deverá fazer-se através das ruínas de um núcleo habitacional que se articulava ao longo de uma das calçadas deste oppidum romanizado, pavimentadas com grandes lajes de calcário.

Para vencer o declive onde algumas dessas casas se implantaram e tendo em vista aceder pedonalmente à calçada, foram edificadas, em período romano, duas grandes escadarias utilizando silhares aparelhados. No espaço que as medeia definia-se uma insula.

Quem visitar Miróbriga fazendo a entrada através do "Núcleo Interpretativo" terá como primeiro cenário as estruturas arqueológicas anteriormente referidas e, num ponto mais alto, a capela seiscentista de S. Brás. Inflectindo para Nascente serão visívies os restos da zona habitacional articulados com a rede viária que conduz ao forum, implantado numa zona altaneira, e às termas, num ponto baixo - Fot 1.

\section{Caracterização de Miróbriga}

\section{Quadro geográfico}

Miróbriga fica situada no Sudoeste alentejano (Lám. 1), nas proximidades da cidade de Santiago do Cacém, sede do concelho com o mesmo nome (Lám. 2).

Localiza-se no limite de uma faixa acidentada que se desenvolve a Este, constituída pelos contrafortes da Serra de Grândola e do Cercal, de que a colina onde se situa o oppidum se pode considerar a retaguarda. Esta faixa acidentada corresponde, genericamente, à mancha xistosa do Carbónico. A Oeste, desenvolve-se uma faixa costeira, plana. Uma série de lagunas faz o contacto entre a terra e o oceano, fertilizando as zonas mais interiores (Lám. 3).

- A realização de escavações;

- O registro gráfico e topográfico de estruturas arqueológicas do fonum e envolvente:

- A limpeza manutenção da estação arqueologica;

- As obras de recuperação da capela de S. Brás e da área envolvente. 
A área que corresponderia ao núcleo urbano de Miróbriga e zonas limítrofes é caracterizada, do ponto de vista litológico, por afloramentos xistosos, que confinam com uma faixa de arenitos e de conglomerados com cimento argilo-ferroso e outras com argilas, calcários margosos e calcários dolomíticos.

As construções de Miróbriga utilizam, na sua maioria, os materiais litológicos locais, à excepção de alguns elementos arquitectónicos ou epigráficos que utizam o calcário fétido de S. Brissos.

Região de clima temperado oceânico, húmido e moderadamente chuvoso ou «marítimo de fachada atlântica», a zona de Santiago do Cacém regista uma temperatura média anual de $15,8^{\circ} \mathrm{C}$ e uma amplitude térmica anual de $11,2^{\circ} \mathrm{C}$, condições estas que não se deverão alterado muito desde o período romano. A amplitude térmica atenua-se à medida que se caminha para o mar.

Sendo caracterizada por uma humidade relativa elevada e por um alto nível de pluviosidade que, no Inverno, contribui para engrossar as ribeiras que fertilizam a "campina", pode considerar-se uma região muito fértil do ponto de vista agrícola, permitindo também o desenvolvimento da fruticultura ${ }^{4}$, atestada arqueologicamente desde a ocupação romana (DARLING et alii, 1984: 51).

O Alentejo deveria ser, em período romano, coberto de florestas de sobreiros e azinheiras ${ }^{5}$, as primeiras mais frequentes na parte ocidentale nas terras mais altas; as segundas no interior e nas encostas voltadas a Leste (ALARCÃO, 1974: 4). Menos frequentes seriam os pinheiros mansos ${ }^{6}$. Lobos, javalis e veados povoariam uma mata formada por zambujeiros, medronheiros, loureiros, urze branca, entre outras espécies vegetais. Nas zonas xistosas as estevas cresceriam em grande quantidade, como ainda hoje se verifica em parte do concelho de Santiago do Cacém.

À excepção de algumas terras férteis dos rios Mira e Sado os solos alentejanos eram, em grande parte, pouco fecundos.

\footnotetext{
${ }^{4}$ A equipa americana que trabalhou em Miróbriga refere a existência de uvas, figos, romãs, amêndoas e nozes. Quer Bernardo Falcão, no século XVIII, quer o Padre Macedo e Silva se referem ainda no século XIX à abundância de pomares na região. Na zona adjacente a Miróbriga existem ainda actualmente alguns pomares.

${ }^{5}$ Como aliás acontece ainda actualmente na região de Santiago do Cacém, que se admite pertencer à Formação Vegetal designada como Carvalhal da zona Húmida-Quente (CABRAL, Caldeira, 1960) dominada pelo sobreiro, azinheiro, carrasco, zambujeiro, pinheiro manso. Os arbustos que mais comummente se lhe deveriam associar são: o abrunheiro bravo, a murta, a urze branca, a roseira branca, a madressilva caprina actualmente rarefeitas devido aos trabalhos agrícolas e mesmo arqueológicos (FORTES, Mário, 1997: 10).

${ }^{6}$ Segundo informações da equipa luso-americana, foram encontrados carvões de carvalho e de Pinheiro, datando de período pré-romano (SOREN, 1983: 59).
} 
Pesem os resultados da investigação recente que têm vindo a questionar esta opinião, nomeadamente as prospecções efectuadas em torno da uilla romana de S. Cucufate, que apontam para a existência de numerosos «estabelecimentos agrícolas secundários, tipo casal ou uilla rustica» (MANTAS: 1988: 207 e 208), bem como os levantamentos feitos em redor de Ebora, que demonstraram a predominância de unidades agrícolas de pequena dimensão (BARATA E MASCARENHAS, 1997: 6667), as grandes unidades agrárias, as culturas pouco diversificadas e a fraca densidade populacional devem ter caracterizado grande parte do território alentejano desde a Antiguidade, fenómeno que se deve ter acentuado a partir do século III d.C. (op. cit.: 208; ALARCÃO, 1990: 419).

A produção de trigo apenas se conseguia poupando os solos pelo recurso ao afolhamento, sendo a sua rentabilidade muito baixa. A fraca produtividade só tornava, assim, rentáveis as culturas extensivas e a pecuária, pelo que certas zonas do Alentejo se caracterizaram, ao longo do tempo, pela existência de grandes latifúndios e pelo povoamento menos denso (ALARCÃO, 1990': 419) ${ }^{7}$.

A exploração pecuária fazia parte da exploração das uillae, actividade que parece ter tido continuidade neste território ao longo dos séculos ${ }^{8}$, atestada pela importância económica que ainda nos nossos dias tem a produção de gado bovino, caprino, ovino, suíno e equino. Hoje reduzida no Sudoeste alentejano, a produção de azeite e a vinicultura parece ter sido abundante no período romano, tendo-se mantido durante a Idade Média e Época Moderna.

É relativamente mal conhecida a estrutura agrária romana na área que estudamos, uma vez que na área adjacente apenas foram referenciados alguns indícios de uillae.

Se bem que sejam escassos os vestígios de casas agrícolas identificados na área circundante a Miróbriga, em Alvalade do Sado, a aproximadamente $20 \mathrm{~km}$, conhecemse várias uillae romanas, que deveriam pertencer a um conjunto mais vasto de pólos de exploração agro-pecuária, em íntima relação com a grande bacia hidrográfica do Sado.

\footnotetext{
${ }^{7}$ Durante a Idade Média, a grande propriedade continuou a caracterizar o território que teria pertencido à ciuitas de Miróbriga, tendo sido entregue, como tantos outros, à Ordem de Santiago que se encarregou de o povoar e desenvolver. Desde os primeiros documentos conhecidos sobre Santiago do Cacém, há uma referência constante a actividades ligadas à agricultura e à pastorícia, bases da economia medieval. A referência aos pomares desta região são também constantes. A partir do século XVII, são inúmeras as notícias referentes a essas actividades, acentuando a predominância da agro-pecuária que, ainda hoje, caracteriza o território. Data de 1763 uma regulamentaçāo das actividades agrícolas. A produção de azeite e mel e a extracção e transformação da cortiça são aqui referidas como as actividades principais.

${ }^{8}$ Para este tema, poder-se-á também consultar os capítulos «Quadro Geográfico» e «Economia e Sociedade» da obra de M.V. Gomes e Armando Coelho F. Silva Proto-História de Portugal.
} 
Também não foram ainda identificados vestígios de estradas vicinais, dos eixos viários estruturantes deste território no período romano. Pensamos, contudo, que deverão ter-se mantido praticamente os mesmos durante toda a Idade Média e Época Moderna.

A ponte do Cacém, à saída de Santiago do Cacém, possivelmente construída no século XVI, deve sobrepor-se a um caminho anterior que ligaria esta povoação a Sines. Não se conseguiu detectar, no entanto, na construção desta ponte indícios da uma origem mais antiga.

Em Alvalade do Sado uma ponte de origem medieval pode ter dado continuidade a uma via romana que ligaria Miróbriga a Pax Iulia, passando por Aljustrel.

A exploração mineira que já deveria ser, nesta zona, do conhecimento dos romanos, sofreu, no século passado, um grande desenvolvimento na região, e continua, nos nossos dias, a constituir a grande fonte de riqueza do $\mathrm{Cercal}^{9}$. Mais para Norte, mas ainda pertencendo, em período romano, à ciuitas de Miróbriga, desenvolviamse as minas da Caveira, onde foi atestada mineração antiga.

Através de uma carta de distribuição de estações da Idade do Ferro publicada por Teresa Gamito (JÚDICE GAMITO, 1986: 193-94), conhecem-se cerca de cinquenta povoados a Sul do Tejo, sendo evidente a sua implantação em locais-chave de exploração agrícola e mineira ${ }^{10}$.

A óptima situação geo-estratégica, permitindo um eficaz domínio territorial, associada aos recursos naturais agrícolas e mineiros deve ter conferido a Miróbriga importantes funções comerciais.

No entanto, só a continuação das prospecções e o levantamento exaustivo dos povoados mineiros circundantes (BERROCAL RANGEL, 1995: 168) poderão confirmar esta hipótese.

\footnotetext{
${ }^{9}$ "A faixa piritosa portuguesa estende-se por duas bandas grosseiramente paralelas, entre a região de Alcácer do Sal e a fronteira com Espanha, devendo ainda nela ser incorporada a Serra do Cercal (OLIVEIRA, Tomás e Vitor, 1996: 11). Segundo um levantamento feito por João Madeira e por José Matias, verifica-se que, nos arredores de Santiago do Cacém, são inúmeras as explorações mineiras ao longo dos século XIX, quer se tratem de ouro, prata, ferro, galena, cobre, entre outras. Em prospecções recentes com a participação da signatária foram também detectados inúmeras galerias mineiras relativamente próximas de Santiago do Cacém, desactivadas actualmente, mas às quais ainda não foi possível atribuir cronologia.

${ }^{10}$ Os recursos mineiros e agro-pecuários devem ter condicionado, desde a Idade do Bronze, todo o povoamento no Sul da Península Ibérica, processo que conduziu a uma complexificação económica e social e que culminou, durante a I Idade do Ferro, com o desenvolvimento de áreas acentuadamente comerciais ou entrepostos, muitas das quais fruto de presenças alógenas (GOMES, 1994:129).
} 
O rio Sado, que deverá ter funcionado em período romano como um limite natural do território de Salacia (MANTAS, 1990: 175) e de Miróbriga, foi durante toda a Proto-História uma via fundamental de ligação ao hinterland.

Miróbriga controlaria, pois, um vasto território que poderia ir até Sines, a Ocidente, pesem embora os achados que, nesta última vila, podem fazer equacionar a verdadeira importância desta localidade, em período romano.

A estreita ligação com esta cidade está, de certo modo, comprovada, porque em Miróbriga está atestada epigraficamente uma família que se encontra também em Sines (ENCARNAÇÃO, 1984: 230; ALARCÃO, 1985²: 109). Essa inscrição a que se têm levantado muitas dúvidas (ALMEIDA, 1964: 12; ENCARNAÇÃO, op. cit., loc. cit.; RIBEIRO, 1982-83: 175) diz respeito a um homenageado cuja profissão poderia ser caudicarius (armador ou proprietário de embarcações) o que poria em relevo as actividades marítimas na região, e nomeadamente as do porto de Sines. A importância económica destas actividades teria permitido a Marco Júlio Marcelo exercer, em Miróbriga, as funções de edil e duúnviro (ALARCÃO, 1985: 110; ENCARNAÇÃO, 1996: 136).

Se bem que não sejam bem conhecidas, nesta zona, as modificações das linhas da costa que participam nas alterações das formações lagunares, é óbvia a sua mobilidade em todo o litoral alentejano (FONSECA, 1993: 11-28). A demostrá-lo é a representação na cartografia existente desta zona, dos séculos XVI e XIX, de uma curiosa lagoa, denominada comummente como «da Pera», que se desenvolveria até às proximidades de Santiago do Cacém. A confirmar-se a sua existência, poderia justificar-se a ocupação deste lugar, pois permitia um contacto directo, mas protegido, com o mar desde épocas remotas (BARATA, 1993, GTL).

Embora não sejam conhecidos vestígios romanos de actividades ligadas à pesca ou à salga de peixe nas proximidades das lagoas que se situam no actual concelho de Santiago do Cacém, vários vestígios arqueológicos localizados no município de Sines comprovam a importância das actividades piscícolas no litoral alentejano.

Admitindo-se assim uma certa continuidade na rede de relações urbanas pré-romanas e romanas, Miróbriga deveria, pois, ter funcionado como núcleo polarizador da região já na Idade do Ferro. A teia de relações entre Miróbriga e o porto de Sines, a Oeste; entre Miróbriga e as povoações a Norte (Salacia, Caetobriga?); entre Miróbriga e o Sul (llha do Pessegueiro, Porto Covo, Vila Nova de Milfontes e Odemira) e ainda entre Miróbriga e as zonas do interior, deveria ter-se reforçado com a dominação latina. Ficaria, deste modo assegurado, por um lado, o fornecimento dos produtos agrícolas e piscatórios à ciuitas e, por outro, o escoamento dos minérios de que é rica a região adjacente a Miróbriga, salientando-se o cobre e o ferro (Lám. 4). 


\section{A identificação de Miróbriga com o local que estudamos}

Várias inscrições têm servido de base à identificação deste local com a Miróbriga dos Célticos de Plínio (ALMEIDA, 1964 e 1988: 22-23), não podendo a maior parte delas ser tomada em consideração ou, pelo menos, ter uma interpretação inequívoca (ENCARNAÇÃO, 1984, IRCP n 149, n 150).

Uma delas, proveniente da Herdade Francisquinho, freguesia de Santa Cruz (aprox. $4 \mathrm{~km}$ de Miróbriga), se bem que tenha fundamentado algumas das teorias que permitiam identificar Miróbriga com o local agora em estudo, uma vez que o defunto se afirma mirobrigensis celticus, tem também levantado bastantes questões sobre a sua autenticidade ${ }^{1 !}$.

A localização de Miróbriga na foz do rio Mira tem sido também admitida por alguns investigadores portugueses, nomeadamente pelos epigrafistas Cardim Ribeiro e José d'Encarnação, que coloca algumas dúvidas à correlação directa entre a inscrição do magistrado do Município Mirobrigense, encontrada nas proximidades, e o aglomerado urbano a que nos referimos (Lám. 5).

As fontes literárias, nomeadamente a referência de Plínio a um oppidum estipendiário (Nat. Hist. IV, 116) não nos permite, contudo, assegurar a localização exacta desse aglomerado urbano.

Por outro lado, também a ocupação pré-romana do local é mal conhecida. Nem designação de "Miróbriga Céltica" nos pode servir de referência segura sobre os povos que aí habitaram em período pré-romano, sendo designados pelos autores gregos e latinos como Celti várias gentes do tronco indo-europeu, sem que correspondessem, contudo, a um povo homogéneo, com uma comunidade linguística própria, claramente diferenciado dos seus vizinhos ou estanques à miscigenação com outros povos

\footnotetext{
" «Efectivamente se a análise paleográfica nos deixa algumas dúvidas, sabemos, por outro lado, que, normalmente, quando alguém morre na sua localidade de origem, não indica a naturalidade, seria desnecessário; por outro lado, sendo mirobrigense na sua própria terra, que necessidade haveria de especificar a sua qualidade de "céltico"? Além disso, tendo-se posto tanto empenho em fazer notar a naturalidade do defunto, não houve igual intenção de afirmar para a posteridade a sua condição de homem livre, indicando a filiação ... . Poder-se-ia, pois, suspeitar da autenticidade deste monumento, eventualmente forjado com a intenção de bem especificar o nome da povoação cujas imponentes ruínas se encontraram em Santiago do Cacém» (ENCARNAÇÃO, 1984: 232-234). Jorge de Alarcão, não obstante, defende que não se pode tomar como «norma absoluta que a naturalidade não se indica quando alguém é homenageado ou morre na sua terra e que, inversamente, se indica sempre que alguém se homenageia ou enterra fora da sua terra natal» (ALARCÃO, 1985:105). Cardim Ribeiro reforça a problemática referente à identificação de Miróbriga com este local, pois, embora ressalvando que a inscriòão de Miróbriga é "controversa", continua a admitir que a «menção da origo numa inscrição funerária indica que o indivíduo nomeado faleceu e foi sepultado fora do territorium da sua ciuitas» (RIBEIRO, 1994': 80).
} 
(KURTZ, 1995: 26; ENRÍQUEZ NAVASCUÉS, 1995: 65). Embora sendo relativamente unânimes em afirmar que a região compreendida entre o Tejo e o Guadiana era habitada pelos Célticos, pouco ou nada nos esclarecem, no entanto, sobre a sua distribuição, tipo de povoamento ou sobre o sistema social em que se inseriam, o que dificulta a compreensão da geografia política neste período (FABIÃO, 1992: 170).

Há ainda a acrescentar que em Miróbriga não são também conhecidos materiais arqueológicos que a possam inscrever inequivocamente nessa tradição cultural.

Contudo, o topónimo Miróbriga denuncia a possível origem"céltica" da ocupação sidérica do local, como se pode deduzir pelo topónimo terminado em "briga".

Apesar de todas as dúvidas que se levantam à identificação de Miróbriga ou à sua ocupação pré-romana, parece-nos ser lícito, dadas as características do local e da implantação deste povoado fortificado, reconhecer-lhe um papel estruturante, desde períodos pré-romanos, no território compreendido aproximadamente entre a bacia do rio Sado e o mar.

\section{Tipo de aglomerado urbano}

A partir de pelos menos o século II a.C. Miróbriga entra na esfera de influência romana e, no século I d.C., foi implementado um programa de amplas construções, tendo-se estendido o aglomerado urbano também para as zonas mais baixas.

Interpretado durante décadas como um «Santuário Rural» (ALMEIDA, 1964: 30) por alguns investigadores, sendo mesmo algumas das suas infra-estruturas justificadas como local de distraç̧ão dos peregrinos, essa opinião era baseada na concentração de templos e no desconhecimento de zonas habitacionais que comprovassem a existência de uma grande população fixa.

A sacralidade sustentava, portanto, a importância do local, conferindo-lhe de per si uma excelência no contexto nacional.

No entanto, no que diz respeito a Miróbriga, se analisados, caso a caso, os argumentos que justificaram a designação de «Santuário Campestre Romano», com os seus «três elementos indispensáveis: o templo, as termas e o edifício para divertimento dos devotos peregrinos, que aqui é um circo» (ALMEIDA, 1964: 71-2 e 1988: 1920) e a associação do mesmo ao culto do deus de origem grega de Esculápio $^{12}$, parecem manifestar-se controversos os dados em que assentam.

${ }^{12} \mathrm{O}$ culto a Esculápio está comprovado epigraficamente na Hispânia somente na Tarraconense em Valência
existe um pedestal dedicado a Asclepio por um sevir augustal e na Lusitânia, não sendo, contudo, conhecidos 
A inscrição dedicada a Esculápio, tida por alguns autores como uma das provas abonatórias para considerar este local como um "Santuário Rural" dedicado a essa divindade, foi colocada no século XVI numa das paredes dos Paços do Concelho e, posteriormente, Hospital Velho ou do Espírito Santo de Santiago do Cacém, desconhecendo-se a sua proveniência exacta. Continuamos a admitir, contudo, que tenha pertencido a Miróbriga. No entanto, não são conhecidos em Miróbriga nem exvotos que confirmem as práticas curativas da incubatio, nem é possível atestar a existência de libações ou sacrifícios dedicados a Esculápio.

Por outro lado, esta inscrição dedicada a Esculápio através de um «legado testamentário ... feito por medicus pacensis: verosimilmente, Gaio Átio Januário, que deixou dinheiro ao conselho municipal de Miróbriga para que ele organizasse ou continuasse a organizar os Quinquatrus em honra de Esculápio» ${ }^{13}$ (ENCARNAÇÃO, 1984: 219) poderá apontar para a existência de ludi circenses dedicados à divindade.

José d'Encarnação, regressando à análise desta inscrição, reconhece que a mesma não se trata de uma placa mas de uma ara, o que pressupõe a existência de um templo dedicado a Esculápio em Santiago do Cacém e a consequente grande devoção a esta divindade no local (ENCARNAÇÃO, 1991: 186). Não fica, contudo, justificada por esse facto a sua directa correlação com o templo centralizado no forum de Miróbriga.

No território actualmente português são conhecidos outros exemplos da dedicação a esta divindade. Se bem que não esteja comprovada arqueologicamente a existência de quaisquer práticas curativas de incubatio, é evidente a associação desta divindade a actividades ou locais de índole terapêutica ou a votos de cariz salutífero ${ }^{14}$.

\footnotetext{
quaisquer cultos colectivos de cidades ou uici nem dedicatórias oficiais. Os seus dedicantes são varões, libertos na sua maior parte. Somente numa inscrição (León) o seu nome aparece associado à saúde (MAÑANES, 1983/ 84: 228-29; VAZQUEZ Y HOYS, 1981: 172). No caso de Miróbriga essa associação é indirecta pois o dedicante dá a conhecer a sua profissão de médico. Também é apenas conhecido um templo dedicado a esta divindade, em Ampúrias (VAZQUEZ Y HOYS, 1981: 173). Na Bética, em Nova Cartago, existe uma edícula consagrada o culto de Esculápio (BLÁZQUEZ, 1991: 284). Alguns autores justificam o culto de Esculápio e de Vénus em Miróbriga como sobrevivência, graças à interpretatio, de divindades locais que, segundo este investigador, poderiam ser versões romanizadas de Eshmun e de Tanit (MANTAS, 1996²: 350-51).
}

${ }^{13}$ Pesem as reticências que vários autores têm colocado e que se possam continuar a levantar em relação à interpretação desta inscrição e à atribuição das Quinquatrus a Esculápio, o epigrafista José d'Encarnação conclui da transposição do culto de Minerva para Esculápio, dadas as qualidades medicinais da deusa e conclui que Miróbriga pudesse, de facto, funcionar como local de peregrinação e que «num santuário, Esculápio era anualmente festejado decerto por causa das curas miraculosas que ali operava» (op. cit: 21819). Este investigador atribui a inscrição ao século II d. C. Num artigo recente, José d'Encarnação retoma a questão do estatuto de Miróbriga, reafirmando a importância desta epígrafe para concluir da existência da "ordem dos decuriões" e, portanto, de "conselho municipal" (ENCARNAÇÃO, 1996: 133).

${ }^{14}$ Em Olisipo, uma das três inscrições consagradas a Esculápio, datável do século I d. C., foi, provavelmente, encontrada nas ruínas do criptopórtico a que foi, durante muito tempo, atribuída uma função termal, sendo, 
Se atendermos ainda à relação existente entre as divindades e as virtudes imperiais (ÉTIENNE, 1974: 333) e ainda à associação entre as mesmas e «as condições e qualidades vitais à sobrevivência cultural, política e económica do Império Romano ... que aspira, em primeiro lugar, à Aeternitas» (RIBEIRO, 1982/83: 201; 1994: 194) não é pois de estranhar a sua conotação com alguns cultos salutíferos, como se verifica, nas províncias ocidentais, com o "culto das águas" (idem,1982: 188).

Pelo anteriormente exposto, podemos admitir que, em Miróbriga, Esculápio, pelas suas características médico-terapêuticas, e se bem que não sendo nomeado com o atributo de Augusto, possa funcionar como um dos guardiães da Salus Augusta ${ }^{15}$ e associar o seu culto e dos ludi dedicados em sua honra à pessoa do imperador ${ }^{16}$.

Revela-se, deste modo, esclarecedora a associação, em Miróbriga, de outras divindades, atestadas epigraficamente, tais como Marte ${ }^{17}$ e Vénus.

O culto a Vénus ${ }^{18}$, comprovado epigraficamente e ainda através do aparecimento de uma estátua da deusa, provavelmente do século II d. C. ${ }^{19}$, deve estar associado ao culto da família imperial (ENCARNAÇÃO, 1984: 222; RIBEIRO, 1982-83: 205).

portanto, o edifício conhecido como "Termas dos Augustais". Deve-se essa designação ao facto dos dois dedicantes da inscrição votiva, que oferecem o monumento ao Município (MAN'TAS, 1994: 218), se tratarem de Augustais, o que confirma a importância do culto imperial neste território. No entanto, daí não se pode concluir uma associação nítida entre o culto de Esculápio e a existência de um edifício termal, mas apenas a íntima ligação do culto de Esculápio e do culto imperial às águas salutíferas e purificadoras, que neste caso parecem relacionar-se com um «forum dos mercadores» (RIBEIRO, 19942: 193). Numa outra inscrição de Olisipo a divindade aparece mesmo mencionada como Aesculapio Aug (CIL, II, 174)

${ }^{15}$ A associação entre esta divindade e a referida virtude Salus Augusta já havia sido proposta por José Cardim Ribeiro (RIBEIRO, 1982/83: 204). Essa relação torna-se inequívoca na estátua descoberta no interior de umas termas romanas no Monte da Salsa, Brinches, Serpa, onde sobre o corpo representando Aesculapius foi colocada a cabeça-retrato de uma personagem identificada com o imperador Adriano (SOUZA, 1990; MATOS. 1995: 50).

${ }^{16} \mathrm{O}$ hipódromo e o anfiteatro eram fundamentais ao desenrolar das sacra Augustalia que contemplavam obrigatoriamente a existência de ludi. Os locais de espectáculo hipódromos, anfiteatros e teatros tornaram-se, pois, fundamentais ao desenvolvimento dos cultos oficiais e dos circuitos litúrgicos de exaltação imperial (GROS, 1990: 381-390).

${ }^{17}$ Provavelmente associado a Victoria Augusta.

${ }^{18}$ Vénus, protectora da gens Iulia e com ela do Império, funciona como um dos garantes da nova "Idade de Ouro" (GROS, 1994: 21-22) tendo o culto a esta divindade atingido o seu auge no reinado de Adriano. Em Seilium apareceu uma cabeça de Vénus, atribuível à época de Adriano (ALARCÃO, 1990²: 51).

${ }^{19}$ Encontra-se no Museu Municipal de Santiago do Cacém. Para esta estátua, de proveniência desconhecida, existe um paralelo no Museu Nacional de Arqueologia do Dr. Leite de Vasconcelos, onde a deusa é igualmente representada sobre um plinto, com um vaso para conter água lutrophoros e que serve de suporte ao vestuário (SOUSA, 1990: 62; MATOS, 1995: 70/71). Segundo este autor esta escultura deverá ser datável do século II d. C. 
Por seu lado, consagrada a Marte é uma inscrição, da qual apenas existe cópia no Chafariz da Senhora do Monte, Santiago do Cacém, em honra de um indígena romanizado: Gaio Pagúsico Marino (ALMEIDA, 1964: 74). Marte assume aqui características funerárias e votivas (ENCARNAÇÃO, 1984: 221). Estas duas divindades poderão, pois, ser associadas ao culto imperial.

São ainda reconhecidos em Miróbriga outros cultos, se bem que de alguns deles apenas haja conhecimento através de fontes escritas. O Padre Macedo e Silva referia, no século XIX, o aparecimento de «divindades romanas», nomeadamente «alguns Penates e um Priapo» aquando das escavações que Frei Manuel do Cenáculo promoveu em 1800.

Autores houve também que quiseram ver em Miróbriga uma forte devoção a Vulcano, e que defenderam a existência de um templo dedicado a essa divindade, baseando-se numa informação do Humanista André de Resende sobre «uma pequena estatueta de bronze de Vulcano Cyrio». Sem termos quaisquer notícias sobre o paradeiro da referida estátua, nem do local exacto onde ela teria aparecido e não havendo qualquer outro paralelo na Lusitânia, não deixa, contudo, de ser curiosa a associação que Bernardo Falcão, autor do século XVIII, faz entre a mesma e a existência de forte exploração mineira desde remotas épocas, porque em Miróbriga e áreas limítrofes é muito comum o aparecimento de grandes concentrações de escória metálica.

A concentração de escória de ferro no interior de uma casa em fase de escavação que se situa no declive existente junto à actual entrada da estação arqueológica fazem-nos indubitavelmente concluir da existência de processos de manipulação metalúrgica, que se concentrariam, com bastante probabilidade, do lado poente deste aglomerado.

A atestar essa importante actividade existem no Museu Municipal de Santiago de Cacém dois exemplares de cadinhos de fundição de grandes dimensões provenientes de Miróbriga (Lám. 6).

Inclinamo-nos, portanto, a aceitar que a riqueza metalífera pode ter sido um dos factores determinantes da ocupação deste local ${ }^{20}$, funcionando Miróbriga como uma espécie de "tampão" de acesso à zona mineira e aos povoados do interior da serra, o que justificaria também a localização do oppidum pré-romano. ${ }^{21}$

Deste modo, e apesar de existirem vários relatos sobre estatuária de índole religiosa, epígrafes de consagração a divindades e ainda vestígios arqueológicos que

\footnotetext{
${ }^{20} \mathrm{Na}$ "Miróbriga Túrdula" encontraram-se também abundantes escórias de fundição (PASTOR, 1993: 614) , parecendo que o controle aos minérios deve ter justificado a ocupação do local.

${ }^{21}$ Curiosamente, na estaçāo arqueológica da Cerradinha, nas margens da lagoa de $\mathrm{St}^{\circ}$ André, a actividade metalúrgica está atestada desde a Idade do Bronze, tendo aí sido encontrados dois fragmentos de cadinhos, utilizados respectivamente para a fundição de estanho e de ferro (GOMES e SILVA, 1994: 110).
} 
apontam para a existência de vários templos de período romano, não podemos, pois, concordar que estes dados conduzam à caracterização de Miróbriga como apenas um "Santuário Rural".

Um fragmento marmóreo, proveniente de Miróbriga, e que se encontra no Museu Municipal de Santiago do Cacém, poderá ter pertencido a uma estátua da deusa Cibele, com uma torre e respectiva porta. Esta representação de uma Cibele citadina, admitindo que efectivamente se trata de um fragmento da torre que encimava o penteado da deusa, aponta, ao invés, para um símbolo propiciatório de cariz urbano, a alegoria da Cidade ${ }^{22}$.

A questão da sacralização do local, já em período pré-romano, foi retomada pela equipa luso-americana que trabalhou em Miróbriga nos anos 80, que atribuiu a uma das construções de forma inicialmente quadrangular a função de um templo da II Idade do Ferro datável do século IV a. C. (BIERS et alii: 1982: 40 e 1983: 54). Numa segunda fase, o templo teria sido reedificado, sendo dotado, segundo D. Soren, de pronaos, cella e temenos, correspondendo-lhe o "depósito votivo" a que seguidamente faremos referência.

Dada a sua localização, adossada à muralha e paralela a outras construções do mesmo tipo, e à sua planta rectangular (que, aliás, ainda está indefinida em alguns pontos) comum aos povoados desta época ${ }^{23}$ somos da opinião que a sua funcionalidade fosse mais "profana", tratando-se de uma das várias construções que se edificaram em Miróbriga na II Idade do Ferro. Estas construções poderiam ter funcionado como habitações ou, pontualmente, como locais de armazenamento, contribuindo para reforçar a própria defesa. Exemplos destes são comuns a inúmeros povoados da Idade do Ferro, de que Pedrão, Setúbal, é um bom paralelo (SILVA e SOARES, 1973; BARATA, 1994: 128; CORREIA, 1995²: 251). Ou questionarmo-nos ainda se não se tratará apenas de uma casa subdividida em dois compartimentos, por "bancos ou muretes" 24 , arquitectura comum a outros povoados sidéricos peninsulares. Podemos

\footnotetext{
${ }^{22}$ Proveniente de Myrtilis existe um exemplar de inícios do século I com a simbologia da corona murabilis no alto da cabeça, representando Cibele (SOUZA, 1990: 9; MATOS, 1995: 54/55). A corona muralis, que era concedida aos militares que primeiro entrassem numa muralha inimiga, representava uma cidade amuralhada ou uma torre, ou seja era a metáfora de uma cidade ou país (LIBERATI, 1988: 65). De referir ainda o exemplar, proveniente de Itálica, publicado como tratando-se de uma representação de Tyche-Fortuna ( $L a$ Ciutat Hispano-Romana, 1993: 20, 21 e 263 e LEÓN, 1995: 146).

23. Em Conímbriga a maioria das casas da Idade doFerro apresenta uma plantaquadrangular(ALARCÃOeETIENNE, 1977, I*: 22). No entanto, já em na citânia de Briteiros e na citânia de Sanfins existem perto das construções circulares, que são dominantes, algumas de planta quadrangular (CENTENO e SILVA, 1996: 134 e 136).

${ }^{24}$ As plantas publicadas por Berrocal de Castro de Capote apresentam-nos também vários exemplos de casas subdivididas em dois compartimentos (BERROCAL, 1992: 180 e 222) que poderão também admitir-se como paralelos para a planta da construção de Miróbriga, em análise.
} 
ainda referir, para reforçar a hipótese de uma construção doméstica, que o século III a. C. assiste à divulgação da "casa com vestíbulo", bem documentada em vários povoados, de que, muito possivelmente, a construção de Miróbriga é apenas mais um exemplo (Lám. 7).

Será ainda de salientar que o aparecimento de uma tacinha com ossos invertida, que serviu como um dos "suportes arqueológicos" para admitir as características votivas do espólio e, portanto, a designação de "templo" atribuída à última fase da construção da II Idade do Ferro, poderá não corresponder linearmente à existência de uma construção sacralizada.

A sacralização de um determinado espaço, e de um momento da sua construção, ou mesmo o aparecimento pontual de espólio de caracter votivo ou fundacional, como parece ser o do caso em análise, não pode funcionar de per si como sinónimo de templo, onde se partilha uma sacralidade comungada por uma comunidade. Para especificar esta ideia, gostaríamos de referir que em recentes escavações promovidas em Miróbriga, na "zona habitacional", apareceu, ao nível da fundação de uma casa romana de átrio, escondida no afloramento xistoso de base, uma tigela ou patella invertida contendo no seu interior ossos de frango, que pensamos poder tratar-se de um ritual fundacional. No entanto, não pode daí concluir-se que escavámos um "templo" romano (Lám. 8).

Não obstante, a referência à sacralidade do local desde a Idade do Ferro, a equipa luso-americana considerava este aglomerado urbano não como um santuário, mas assemelhar-se-ia a uma cidade fortificada, «o oppidum de Plínio» (BIERS et alii 1981: 32-33). Por seu lado, o templo centralizado e área do forum apresentava, segundo alguns destes investigadores, características de um capitolium provincial (BIERS et alii, $1981^{1}$ e 1981²: 31).

Também esta interpretação nos parece forçada tendo em atenção que, por um lado, são raras as construções efectivamente tidas como capitolia nas províncias ocidentais, seja nas gálicas, africanas ou ibéricas ${ }^{25}$, no século $\mathrm{I}$, nem tão pouco o culto a qualquer uma das divindades da tríade capitolina está comprovado em Miróbriga. Por outro lado, nunca a cidade que estudamos se tratou de uma colónia, condição necessária para se dispor de um capitolium, numa primeira fase da romanização (BENDALA, 1989-1990: 16).

\footnotetext{
${ }^{25}$ Sobre este assunto ver BENDALA, 1989-1990: 11-36. Bendala Galán admite como provável, se bem que não isento de dúvidas, o de Ampúrias, de Sagunto e de Valentia, na Ulterior e o de Itálica, e de Carteia na Citerior, todos datáveis entre o século III a I a. C. Acrescenta-se ainda a existência de um possível capitólio em Pollentia, datado do século II a. C. (ARRIBAS e TARRADELL, 1987: 125).

Gros e Torelli corroboram a opinião de Bendala no que diz respeito à diminuta construção de capitolia nas regiões ocidentais, onde são preteridos pelos templos dedicados ao culto imperial (GROS e TORELLI, 1992: 256). Recentemente Vasco Mantas admite, contudo, a existência de um capitólio em Beja (MANTAS, 1996': 54).
} 
Além de todas estas questões há ainda a acrescentar que, à época da construção do templo centralizado de Miróbriga, em meados do século I, já o culto da tríade capitolina havia, de certo modo, caído em desuso como fenómeno aglutinador do forum, por motivos de ordem ideológica e política que trataremos no ponto referente ao aglomerado urbano.

Admitimos, portanto, que este local, que tem uma ocupação da Idade do Ferro desde os séculos V-IV a. C., onde se vão cruzar influências de cariz continental e mediterrânico, entra na esfera de influência romana a partir do século II a. C., que irá impor no século I d. C. os seus padrões.

Miróbriga tornar-se-á depois município, capital de uma ciuitas, polarizadora de um território, e portanto um aglomerado urbano com as características e as infraestruturas comuns às cidades provinciais do império.

\section{IV. $O$ aglomerado urbano e a sua fundação}

Muito frequente no Sul de Portugal, o topónimo Castelo indicia, em termos genéricos, uma ocupação pré-romana. (MAIA, 1986: 44). Efectivamente, a zona onde se implanta o forum de Miróbriga, conhecida vulgarmente por "Castelo Velho", deve ter sido ocupada desde a Idade do Bronze.

O sufixo "briga"26, comum a mais de uma centena de topónimos peninsulares, numa região designada por alguns autores como "Hispânia indo-europeia" (DIAS, 1997: 25), poderá denunciar a celticização a que temporariamente foi sujeito este território ${ }^{27}$, e encerra, como é assinalado por muitos autores, a ideia de "castelo", "fortificação" ou aglomerado situado num ponto alto.

A existência de uma ocupação sidérica no local que estudamos é confirmada arqueologicamente a partir do século V a. C. (SILVA e SOARES, 1979: 163; PONTE, 1979: 195) ${ }^{28} \mathrm{e}$, apesar das dúvidas levantadas quanto à sua designação e à identificação com a "Miróbriga Céltica", quer as suas características topográficas, quer a existência de uma muralha construída com aparelho pequeno e médio de pedra seca, característico da II Idade do Ferro, poderiam justificar o sufixo "briga" deste oppidum.

A significação do topónimo Miróbriga com o característico sufixo em-briga, muito frequente nas áreas de influência céltica e o radical miro-/-mira que muitos autores

\footnotetext{
${ }^{26}$ Sobre os topónimos com este elemento ver ALBERTOS, 1990: 131-146.

${ }^{27}$ Vasco Mantas considera como possível que «a zona ocidental do Algarve se situasse numa faixa de influência céltica, prolongada para norte até aos confins de Miróbriga» (MAN'TAS, 1997: 289).

${ }^{28}$ Quer as cerâmicas com decoração de cordôes estudadas por C.T. Silva e Joaquina Soares, quer as fỉbulas anulares publicadas por Salete da Ponte.
} 
admitem ser uma possível alusão a um rio , é muito comum nos povos hispanoromanos, aparecendo citadas várias cidades distintas nas fontes antigas: a "Miróbriga Céltica" de que tratamos; a "Miróbriga dos Vetões", situada na actual Cidade Robrigo (Salamanca) e a "Miróbriga Túrdula" no "Cerro del Cabezo" de Capilla (Badajoz) (PEDRERO, 1996: 361-62).

O radical deste topónimo tem contribuído, como acabámos de verificar, para que alguns autores associem a "Miróbriga Céltica" ao rio Mira, como já o admitira José Leite de Vasconcelos inclinado-se assim para que a sua localização se situasse em Odemira $^{29}$.

A questão do radical "Mira" foi posteriormente retomada por vários autores que o consideram como vocábulo de origem pré-romana, ou mesmo pré-céltica e que o associam à ideia genérica de "água" ou de rio (QUARESMA, 1986: 83; PASTOR et alii, 1992: 17; PEDRERO, 1996: 362; AMARAL, 1997: 100) ${ }^{30}$.

A referência de Plínio a uma Merobrica entre as povoações costeiras dignas de nota, localizadas entre o Tejo e o Algarve, e aos Stipendiariorum, entre os quais nomeia Mirobrigenses qui Celtici cognominantur (Plínio, N.H. 4,116), e a directa correspondência entre o mesmo e o local que estudamos é difícil de assegurar, uma vez que a inscrição funerária já anteriormente mencionada de Gaio Pórcio Severo, um Mirobrigensis celticus, é de uma autenticidade questionável, quer do ponto de vista paleográfico, quer formal e textual (ENCARNAÇÃO, 1984: 233; 1996: 133-135).

Também Ptolemeu refere uma Miróbriga (G.H., II, 4,10), que, situa entre as 40 cidades turdetanas ${ }^{31}$ que ocupam as terras béticas do interior a Miróbriga Túrdula e uma outra que, muito possivelmente, se trata da povoação a que nos vimos a referir, mas que Ptolemeu coloca na Tarraconense (G.H. II, 6, 58) uma das cidades que atribui

\footnotetext{
${ }^{29}$ José Leite de Vasconcelos, ao debruçar-se sobre uma deidade de nome Mirobieus afirmava «Miro-briga pode significar "fortaleza do Mira"e como na costa occidental, no Alemtejo, fica o rio, palavra que se decompõe, como é sabido em ode-Mira, sendo ode palavra de origem arabiga que quer dizer "rio" ... é de crer que a primeira parte de Miro-briga nada mais seja do que o nome do rio, e que a situação da cidade fosse por aqui e não ao Norte, em S. Tiago de Cacem, onde varios AA. a collocam. ... Curioso é de notar que o deus Mirobeus era adorado dentro tambem de um rio. Talves na lingua indegena, a palavra Mira contivesse uma ideia aparentada com a de "agua"» (VASCONCELOS, 1905, II: 235-36).
}

${ }^{30}$ É aceite que esse mesmo radical Mira se trate, de facto, de um hidrónimo indoeuropeu antigo presente em muitos outros topónimos Miranda, Miragaia, Mirandela, Mirante, em território português, se bem que não necessariamente com o mesmo significado (PEDRERO, 1996: 361-374; AMARAL, 1997: 100, 104). O elemento encontra-se também no teónimo referenciado em Aramenha, Ocrimira (ENCARNAÇÂO, 1975: 255; ALARCÃO, 1988: 158 e 218; PEDRERO, 1996: 362). Sobre o topónimo Miróbriga e as suas referências clássicas, ver PASTOR et alii, 1992:17 e PASTOR, 1993: 601-2.

${ }^{31}$ Segundo Bendala Gálan (BENDALA, 1987) em pleno Alto Império os termos Turdetânia e Turdetanos deveriam já ter perdido o seu sentido original para equiparar-se a povos do Sul Ocidental com forte influência púnica. 
aos Oretanos e que coloca junto de localidades como Salaria, Sisapone, Oretum, Salica, Libisosa e Castulo, entre outras contribui para gerar alguma confusão sobre a localização deste aglomerado ${ }^{32}$.

Marcada por uma componente continental/“celticizante", Miróbriga tornar-se-á permeável às influências das regiões meridionais e costeiras (GOMES, 1994: 173), como o demonstram os materiais anfóricos de origem púnica aí encontrados (SILVA, 1979: 160).

Tratando-se de um oppidum fortificado que foi romanizado, a implantação latina de Miróbriga foi condicionada pela pré-existente ocupação ${ }^{33}$, e a forma como se estrutura a própria ciuitas foi seguramente marcada pela organização territorial precedente.

Sujeita à influência romana desde, pelo menos finais do século III ou inicios do século II a. C. como o demonstram os materiais arqueológicos aí exumados ${ }^{34}$ como alguns espécimes numismáticos, que comprovam a existência de uma circulação monétaria republicana (PEREIRA, 1997:23); as terra sigillata itálica ${ }^{35}$ (FERRER DIAS, 1976-77: 362); algumas "paredes finas - grupo A"36, datáveis de fins da República e

Segundo a informação de Ptolemeu, reafirma-se a presença do cabo Sacro entre os "Turdetanos", numa concepção que abarca provavelmente todo o Baixo Alentejo, uma vez que Pax Iulia, Myrtilis e também Salacia estariam habitadas por "estas gentes". Curiosamente, a Miróbriga Túrdula parece tratar-se, segundo os investigadores que aí vêm trabalhando de uma fundação ex nihilo ou ex novo, se bem que admitam possa ter havido, neste mesmo local ou num próximo, ocupação pré-romana (PASTOR et alii, 1992: 17; PASTOR, 1993: 609).

${ }^{32}$ Luis Berrocal, analisando o texto de Plímio e as diferenças gráficas dos topónimos citados, apresenta como hipótese existirem dois povoados diferentes no Sudoeste peninsular: Mirobriga Celticorum, que situa no local que estudamos, e Merobrica, cuja localização se desconhece, mas que deduz situar-se na costa entre Sines e Vila Nova de Milfontes. Não obstante, inclina-se mais para sua localização na foz do Mira, em Vila Nova de Milfontes, uma vez que Plínio a cita como povoação costeira (BERROCAL, 1992: 64). A. Tovar havia já defendido (1976) também a ideia de que existiriam duas cidades próximas com nomes idênticos. A primeira corresponderia à actual Sines e a segunda à que estudamos. Para a sua localização em Sines inclinamse também outros autores (ALBERTOS, 1990: 139; PEDRERO, 1996: 361).

${ }^{33}$ Situação que é comum a muitos outras povoações romanizadas, e que parece confirmar-se em Tongobriga (DIAS, 1997: 29).

${ }^{34}$ Nomeadamente uma moeda do século I a. C., segundo António Faria, e que foi recentemente encontrada junto à área residencial que escavamos.

${ }^{35}$ De notar contudo que, em Miróbriga, são escassos e pouco antigos os exemplares de terra sigillata itálica, sendo as formas mais comuns as do tipo Goudineau 27 a cronologia dos seus paralelos situam-se por volta de 10 a. C. , como já o afirmara Luísa Ferrer Dias (DIAS, 1976-77:362). À mesma conclusão chegou o estudo feito recentemente por José Carlos Quaresma. Em contrapartida, no que diz respeito às "paredes finas" verifica-se que o "grupo mais antigo (grupo A), na sua maioria importado, está comparativamente bem representado, enquanto os grupos cronologicamente mais tardios, de manufactura ibérica, são menos abundantes» (NOLEN, 1976-77:423).

${ }^{36}$ Nolen chama a atenção para o facto de, num total de 35 fragmentos de "paredes finas", existirem 11 atribuíveis ao Grupo A, datável de finais da República-inícios do período imperial (NOLEN, 1976-77: 425). 
inícios do Império (NOLEN, 1976-77: 425), ou mesmo as campanienses tipo B (ALMEIDA, 1964: 28; ARTHUR, 1983; BERROCAL, 1992: 116)-, Miróbriga terá tido uma ocupação plena a partir do século I d. C. ${ }^{37}$, sendo construídas as infra-estruturas comuns às cidades provinciais ${ }^{38}$, como o forum, na segunda metade da centúria.

A epigrafia confirma essa ocupação plena nos séculos I e II d. C. Verifica-se em Miróbriga a incidência no uso dos tria nomina, reflexo seguro de uma profunda romanização e indicativos da cidadania (MANTAS, 1987: 39 e 1996²: 357), mais comum na epigrafia urbana e rural, mas que em Miróbriga denuncia a origem de uma população de indígenas romanizados (ENCARNAÇÃO; 1984: 217-247). Apesar de não haver praticamente cognomina gregos nem indivíduos que se identificam com um único nome, como acontece nas zonas portuárias e industriais de Tróia e de Salacia (MANTAS, 1987: 39 e 19962: 364) há contudo algumas referências a libertos, como é o caso do testamentário da ara de Esculápio, Gaio Átio Januário (ENCARNAÇÃO, 1984: 218-220).

A política de fomento económico e de desenvolvimento urbanístico prosseguida na Península por todo o século I d. C. recebeu novo impulso na dinastia flaviana, sendo, então, promovidas à categoria de município algumas cidades, entre elas, em território actualmente português, Bracara Augusta, Aquae Flaviae, Conimbriga ou mesmo Tongobriga.

Apesar da inscrição com a qual se tem pretendido atestar a inclusão de Miróbriga entre os municípios flávios da Península não ser isenta de dúvidas, até porque se desconhece o seu paradeiro é, portanto, muito provável que tenha beneficiado do "Édito de Latinidade" decretado por Vespasiano em 73 ou 74 d. C., que concede o ius latii, sendo os seus habitantes inscritos numa das tribos romanas, neste caso a Quirina ${ }^{39}$ (ENCARNAÇÃO, 1984: 223).

A existência de um magister em Miróbriga, Caius Iulius Rufinus, dedicante de uma ara a Vénus, e as funções que Marco Júlio Marcelo deve ter exercido,

\footnotetext{
${ }^{37}$ Para além de um conjunto de estudos publicados que confirmam essa ocupação plena, o recente trabalho de José Carlos Quaresma sobre As Terra Sigillata Focense Tardia e Africana de Miróbriga (inédito) aponta também para essa vitalidade, uma vez que «Miróbriga parece ter iniciado as suas importações de T.S.Af. A desde que esta começou a ser fabricada ne região de Cartago, nos finais do século I d. C., sob a governação dos Flávios», tendência que se acentua entre meados do século II a meados so século IV (QUARESMA, s/d).

${ }^{38}$ Segundo a equipa luso-americana há uma constante nas datas apontadas para o desenvolvimento das estruturas urbanas de Miróbriga, correspondendo a meados do século I d. C. (BIERS et alii, 1984: 51).

${ }^{39}$ Jorge de Alarcão defende como verosímil esta promoção pelos flávios, tanto mais que há uma inscrição que refere um cidadão inscrito na tribo Quirina (ALARCÃO, 1985: 109; MANTAS, 1987: 29).
} 
nomeadamente de edil e duúnviro (IRCP 150$)^{40}$, confirmam a complexificação administrativa a que Miróbriga assistiu, correspondendo ao seu estatuto municipal (ALARCÃO, 1989: 244; ENCARNAÇÃO, 1996: 136).

Segundo o epigrafista José d'Encarnação, magister poderá entender-se aqui, quer no sentido administrativo (chefe de uma comunidade), quer religioso magister é o presidente dum colégio sacerdotal, o encarregado dos ofícios religiosos (ENCARNAÇÃO, 1984: 223) ${ }^{41}$. Admitimos, contudo, que se possa efectivamente tratar de uma função religiosa, tendo em atenção a existência de um hipódromo em Miróbriga e se pesarmos que uma das funções destes magistri era exactamente zelar pela realização dos sacrifícios religiosos e pela realização dos jogos circenses (ABASCAL e ESPINOSA, 1989: 135), também eles de forte componente religiosa.

A ara dedicada a Esculápio, para além da importância religiosa que assume, contém também informações de índole administrativa que importa reter. A referência a splendidissimus ordo que, apesar de não esclarecer o «estatuto administrativo do aglomerado populacional a que diz respeito, não especificando sequer, através dum desejável adjectivo, o nome desse aglomerado ... implica a existência duma organização de tipo municipal, splendidissimus, como é habitual» (ENCARNAÇÃO, 1984: 220). Miróbriga trata-se, portanto, de um aglomerado dotado de ordo decurionum ${ }^{42}$, logo de assembleia ou Senado local ${ }^{43}$, que, como em tantos municípios,

\footnotetext{
${ }^{40}$ De salientar que o exercício de uma magistratura outorgava a cidadania a quem a desempenhava, bem como aos seus ascendentes e descendentes. $O$ direito de cidadania compreendia direitos civis, como o uso dos tria nomia, o direito de connubium e de comercium, bem como os direitos políticos como o voto, ius sufragii, ou de aceder às magistraturas, ius honorum, e o privilégio de servir nas legiões. A existência destes funcionários, para além do que representa em termos jurídico-administrativos, implica a existência de receitas autárquicas próprias as summae honorariae, sobre as quais não há qualquer informação referente às cidades do Portugal Romano. No entanto, estas receitas eram apenas uma parte do rendimento de uma autarquia, que eram reforçados com os impostos sobre o comércio e indústria, as taxas ou tarifas sobre prédios urbanos ou mesmo algumas propriedades rústicas e ainda sobre alguns edifícios públicos, como as termas (ABASCAL e ESPINOSA, 1989: 184; ALARCÃO, 1992: 49-50). O evergetismo privado desempenhava um papel preponderante no financiamento da construção dos edifícios públicos (GROS e TORELLI, 1992: 260). Em Saguntum parece estar bem demonstrada essa atitude no forum, através da doação testamentária do pontifex e edil Cneus Baebius Geminus (ARANEGUI et alii, 1987: 95).
}

${ }^{41}$ Jorge de Alarcão deixa em aberto esta questão, mas inclina-se a admitir que se tratava de uma função possivelmente administrativa, num período em que Miróbriga ainda não era município, sendo, portanto, governada por magistri (ALARCÃO, 1985:110; 1990: 393). José d'Encarnação continua a optar por uma conotação religiosa (ENCARNAÇÃO, 1996: 136).

42 «Os magistrados principais duúnviros, edis e questores depois de desempenharem os seus cargos, colegiais e anuais, integravam o senado local a curia constituindo com os seus familiares o ordo decurionum, na qual, apesar de existir uma assembleia popular, denominada populus, residia o verdadeiro poder» (MANTAS, 1987: 27). O ordo decurionalis ou ordem dos integrava, portanto, a aristocracia das colónias e dos municípios, e a sua pertença contrapunha de per si os seus membros aos restantes cidadãos (ABASCAL e ESPINOSA, 1989: 116). 
deveria sancionar quase todos os actos da vida local e, nomeadamente, a organização dos actos religiosos e do calendário festivo e lúdico e até, com toda a probabilidade, a existência de quinquatrus em Miróbriga.

Em Miróbriga o culto imperial parece esboçar-se já em meados do século I d. C., como o indicia a dedicatória a Vénus de Caius Iulius Rufinus, sendo confirmado através da consagração a essa deusa feita por Flavia Titia, a Marte (IRCP 145) e ainda pela construção de um templo centralizado, dedicado ao imperador, como aliás já vinha a ser admitido por outros investigadores (ALARCÃO, 1989 243-245; BURGHOLZER, 1994: 78-79).

Até ao século III confirma-se uma enorme vitalidade e uma ocupação intensa em Miróbriga, atestada pela concentração de materiais cerâmicos desse período, que tendencialmente vai diminuindo na segunda metade do século IV d. C., sendo muito escassas as importações de Terra Sigillata Africana (QUARESMA, inédito).

As razões que motivaram o abandono de Miróbriga não foram determinadas, mas os vestígios arqueológicos indicam uma gradual desactivação a partir do século IV d. C. (BIERS et alii, 1988: 10). No entanto, não se pode falar propriamente de um colapso, pois apesar da crise de importações que se verifica a partir do século IV, continuam a verificar-se importações de cerâmicas de origem africana a que se juntam trocas com o Mediterrâneo oriental (QUARESMA, s/d - inédito, para publicação).

\section{Características gerais do aglomerado urbano}

Assentando num aglomerado anterior fortificado, a urbanização romana de Miróbriga deverá ter-se adaptado, como já referimos, à ocupação anterior e à topografia do local.

Os romanos utilizaram o alto da "acrópole" ou "fortaleza" pré-romana, dotada de uma muralha construída com pedra-seca numa situação de domínio em relação ao território envolvente a zona do forum romano implanta-se a uma cota altimétrica de $247 \mathrm{~m}$ acima do nível do mar, nomeadamente em relação à faixa arenosa e plana que se estende deste local até ao Oceano, que dista aproximadamente $15 \mathrm{~km}$ em linha recta.

\footnotetext{
Sobre a importância do ordo ver ENCARNAÇÃO, 1993: 59-64. Sobre o merita splendidissimi ordinis e o estatuto municipal de Miróbriga ver também ENCARNAÇÃO, 1996: 133.

${ }^{43}$ Também na "Miróbriga Túrdula" parece ter aparecido uma inscrição onde os municipes seviri do ordo municipal de Miróbriga ordo mirobrigensium fazem uma dedicatória a Antonino Pio (PASTOR, 1993: 605).
} 
Deverão ter utilizado esta zona fortificada, na fase inicial de romanização, se bem que rompendo com o amuralhamento em algumas zonas, como se pode verificar junto do templo centralizado.

Se bem que ainda não sejam bem conhecidos o perímetro e a malha urbana da cidade, que só se poder clarificar com futuras escavações, é manifesto que Miróbriga não apresenta as características ortogonais do modelo ideal de urbanismo romano, a exemplo de algumas fundações do território actualmente português, como Ebora, Pax Iulia, Bracara Augusta, Seilium (MANTAS, 1987: 40-55 PONTE, 1989: 11 ALARCÃO et alii, 1994: 71-81).

As prospecções efectuadas na zona limítrofe e os achados materiais fazem-nos concluir, não obstante, de uma área de dispersão do núcleo urbano semelhante a algumas pequenas cidades da Hispânia, inserindo-se, portanto, no contexto conhecido das províncias ocidentais ${ }^{44}$, ocupando uma área de cerca de 8/9ha. Desconhece-se, contudo, se ela foi intensa e uniformemente ocupada.

Mesmo admitindo que o hipódromo se situaria num local periférico em relação ao centro urbano (este local de espectáculo situa-se aproximadamente a $1 \mathrm{~km}$ a Sul do núcleo urbano), é lógico que na área que os medeia existissem também as estruturas que habitualmente se desenvolvem junto dos núcleos urbanos, tais como as unidades fabris e as uillae.

Pela área de dispersão dos vestígios, a população de Miróbriga não deveria ultrapassar os dois mil habitantes, comum às cidades de pequenas dimensões ${ }^{45}$ (LE ROUX, 1995: 80) sendo, contudo, prematura qualquer conclusão definitiva sobre este assunto, uma vez que não existem sequer dados exactos sobre a dimensão das insulae e sobre os pontos em que as mesmas se distribuíam no aglomerado urbano.

${ }^{44}$ Conímbriga pouco ultrapassava no Baixo Império os 9ha (ALARCÃO, 1992: 47). Tongobriga deveria ter ocupado uma área de 30ha, incluindo as necrópoles, com uma área residencial de cerca de 10ha (DIAS, 1997: 30). Para Seilium é apontada uma área com uma dispersão de vestígios de 28ha (BATATA, 1997: 185). Pax Iulia parece não ter excedido uma área de cerca de 24ha (ALARCÃO, 1990: 47; MANTAS, 1990: 83). Itálica deve ter ocupado uns 30 ha. Baelo ocuparia 10 ha intra-muros e a maioria das suas insulae mediriam em média $46 \mathrm{~m}$ de comprimento e Barcino, na fase inicial (finais do século I a. C. inícios do I d. C.) teria intra-muros 10,4ha (GUITART I DURAN, 1993: 68; GROS, 1996: 45). Tarragona parece ter ocupado, numa primeira fase, 11ha (DUPRÉ, 1990: 319) e Volubilis em Marrocos rondaria os 40ha intra-muros (PONSICH, 1990: 34). A Miróbriga Túrdula ocupava, por seu lado, apenas 3/4ha (PASTOR et alii, 1992: 16).

${ }^{45}$ Tende-se a atribuir à maior parte das cidades do Ocidente uma população oscilante entre 5000 e 20000 habitantes, se bem que a maioria das densidades demográficas tenha sido calculada de uma forma relativamente aleatória (GROS e TORELLI, 1992: 251). Alguns autores têm usado como base dos cálculos uma média de 250 pessoas por hectare (DIAS, 1997: 30). 
Ainda mal conhecido em toda a sua extensão, este aglomerado urbano distinguese pelo seu forum, pela zona residencial e comercial, pelo seu complexo balnear um dos melhor conservados em território peninsular pelas suas calçadas, pelos seus sistemas hidráulicos, pela sua ponte e ainda pelo seu hipódromo, o único exemplar de planta conhecida em território português.

As infra-estruturas hidráulicas devem ter sido em Miróbriga um dos primeiros empreendimentos urbanísticos, a par da construção do forum datado do $3^{\circ}$ ou $4^{\circ}$ quartel do século $\mathrm{I}^{46} \mathrm{e}$ das termas, iniciadas ainda nessa centúria e em princípio da seguinte (BIERS et alli, 1988: 109, 110), que conferem a Miróbriga um cariz urbanístico marcadamente latino.

Sobre o aprovisionamento de água poucos dados se conhecem não tendo sido localizado qualquer aqueduto ou quaisquer fontes, poços ou cisternas que, certamente, existiriam no interior do aglomerado urbano. Apenas os tanques visíveis junto às "Termas Oeste" e o poço de decantação, localizado numa cota mais alta em relação ao topo das mesmas, nos dão indícios dessa preocupação. No entanto, nos terrenos limítrofes a Miróbriga são conhecidos dois poços, cuja origem é seguramente romana.

Atendendo a esses vestígios, torna-se claro que o sistema de abastecimento e de escoamento de águas do complexo termal se desenvolvia para fora da área actualmente posta a descoberto.

\section{V.1. O Forum}

Na zona mais elevada do aglomerado urbano e sobrepondo-se à ocupação anterior, foi edificado um forum - (Láms. 9 e 10).

O forum de Miróbriga pode considerar-se de pequenas dimensões se comparado com outros fora da Lusitânia, nomeadamente alguns situados no actual território português ${ }^{47}$. A largura da praça a céu aberto é de $22,08 \mathrm{~m}$ ( 73 pés) $)^{48}$. O comprimento até ao podium varia entre $25,50 \mathrm{~m}$ ( 85 pés) e $26,40 \mathrm{~m}$ ( 88 pés), tendo em conta as zonas salientes e reentrantes do mesmo. (Lám. 11)s.

\footnotetext{
${ }^{46}$ Para a equipa luso-americana o templo centralizado dataria de meados do século I d. C. (BIERS et alii, 1982: 36).

${ }^{47}$ Segundo Jorge Alarcão, o forum pacense deveria medir aproximadamente 80x 160m, ocupando a basílica o lado sul do mesmo e destacando-se perpendicularmente a ela a cúria, de planta quadrangular (ALARCÃO, 1992:78); o de Conímbriga mediria $23,60 \times 36,80 \mathrm{~m}$, respeitando do ponto de vista da sua modulação os cânones vitruvianos (ALARCÃO e ETIENNE, 1977, I*: 99) e a praça pública de Tongobriga rondaria os 90m de comprimento por 60m de largura (DIAS, 1997: 65).

${ }^{48}$ Uma largura semelhante teriam os fora de Pollentia, com $26 \mathrm{~m}$ de largura, e de Ruscino, com 20m (ARRIBAS e TARRADEL, 1987: 123-125).
} 
A praça pública ao ar livre tem, portanto, um aspecto mais quadrangular, a exemplo de outros fora que, embora mais monumentais, se inscrevem no grupo constituído por recintos dotados de praças quadrangulares, como são exemplo Bilbilis ${ }^{49}$, Baelo Claudia $^{50}$ e Emporiae (JIMÉNEZ, 1987': 89; LEÓN, 1993: 46), e que alguns autores quiseram filiar nos principia (GROS e TORELLI, 1992: 348; EUZENNAT, 1994: 197-203) ${ }^{51}$.

No entanto, se considerarmos o total da praça de Miróbriga contando o sítio onde fecha, junto às alae do templo centralizadoela assume um aspecto mais rectangularmedindo o comprimento total da praça aproximadamente 2 vezes a largura da mesma, podendo definir-se seis módulos. Por seu lado, o seu comprimento pode subdividir-se em três partes, ou módulos: do podium até às alae mede $1 / 3$; o resto da praça $2 / 3$, aproximadamente.

No mais alto dos patamares do forum de Miróbriga foi edificado, como já referido, um templo in anti s $^{52}$, muito provavelmente dedicado ao culto imperial, cujo podium coroa a praça pública.

O templo centralizado tem de largura aproximadamente 1/3 da largura da praça pública. Ladeado por duas alae, em forma de $\mathrm{L}$, que fechavam a praça e que ocupavam, por sua vez, aproximadamente $2 / 3$ da largura da mesma $(1 / 3 \text { cada uma })^{53}$, pode dizerse que o forum era dominado na íntegra por este edifício religioso.

O templo centralizado de Miróbriga mede:

Espaço interior do pronaos: $5,4 \mathrm{~m}$ de largura ( 18 pés) por $2,10 \mathrm{~m}$ de comprimento (7 pés);

A cella tem interiormente $5,4 \mathrm{~m}$ de largura (18 pés) por $7,20 \mathrm{~m}$ de comprimento (24 pés).

\footnotetext{
${ }^{49}$ A praça ou forum de Bilbilis media 48,64m x 44,88m e tinha pórticos à sua volta (MARTÍN-BUENO, 1987: 103).

${ }^{50}$ O forum de Baelo Claudia tem uma forma quase quadrada, medindo 30 x 33m (LÈON, 1993: 46).

${ }^{51}$ Jean Ch. Balty recusa qualquer tentativa de filiação directa dos fora com essas características nos principia. Para este tema ver a sua obra Curia Ordinis, $2^{\mathrm{a}}$ Parte, IV, p. 357 e p. 603. P. Gros também não está de acordo com a marcante influência do modelo dos principia nos fora das províncias ocidentais (GROS, 1996: 220).

${ }^{52}$ No território actualmente português, para além de Miróbriga, conhece-se uma construção do mesmo tipo. Trata-se do templo de Almofala, que foi estudado e publicado por Helena Frade que o classifica como templo próstilo tetrástilo (FRADE, 1994: 1026), e que alguns autores haviam interpretado como edifício funerário (HAUSCHILD, 1989-90: 64). Recentes escavações promovidas em Ammaia, coordenadas por Jorge Oliveira, vieram trazer à luz os restos de uma estrutura, que aparenta ter as características de um podium de um templo (OLIVEIRA et alii, 1996: 17 e 18), provavelmente in antis.

${ }^{53}$ Em Évora o templo municipal/imperial, intimamente relacionado com o culto da água, como acontece com o templo imperial de Mérida (BERROCAL, 1987: 31), ocupa um espaço igual às áreas que o ladeiam até ao pórtico. Cada um dos lados ocupa, portanto, metade. A praça pública corresponde, por seu lado, a uma área igual à ocupada pelo templo e pelo pórtico circundante.
} 
A largura do exterior do edifício é de $7,20 \mathrm{~m}$ ( 24 pés) e o comprimento total exterior é de $12 \mathrm{~m}$ ( 40 pés).

O podium, construído em opus caementicium revestido com placas calcárias, deveria medir aproximadamente $1,50 \mathrm{~m}$ de altura (apesar de muito reconstruído em alguns locais, é clara a construção original) por $15 \mathrm{~m}$ de comprimento, na zona mais próxima da praça pública (50 pés). Esta construção têm também um aspecto bastante cenográfico, formando como que nichos rectangulares e curvilíneos, possivelmente influenciada num pulpitum de um teatro (BIERS et alii, 1981': s/p; ALARCÃO, 1990: 465). O acesso ao templo fazia-se através das escadas laterais do podium.

A maioria dos muros das construções que rodeiam a praça medem $60 \mathrm{~cm}$ ( 2 pés). Apenas diferem os muros do topo sul do forum, que medem $70 \mathrm{~cm}$ e os do templo centralizado, que têm $90 \mathrm{~cm}$ em média.

A Basílica, por seu lado, não corresponde aos cânones vitruvianos, porque o seu comprimento não mede aproximadamente 2 vezes ou três vezes a largura, nem tão pouco se assemelha a uma nave rodeada de pórticos. Esta construção mede internamente $13,80 \mathrm{~m}$ (46 pés) x 9m (30 pés) e tem apenas uma nave. No entanto, se adicionarmos o compartimento que se lhe anexava, correspondendo à Cúria, temos um comprimento total das duas construções de $21,9 \mathrm{~m}$ ( 73 pés) que perfaz mais que o dobro da largura exterior das mesmas $(10,20 \mathrm{~m} 34$ pés) conferindo um cariz mais canónico ao conjunto.

O opus incertum ${ }^{54}$ é o aparelho de construção mais utilizado em Miróbriga, de acordo com o que se passa no resto da Hispânia. De tamanho médio, a maioria dos blocos pétreos utilizados varia entre os 20 a $30 \mathrm{~cm}$. Em algumas construções de Miróbriga, a exemplo das termas e das tabernae, é usado o opus quadratum em "zonas principais" e muito excepcionalmente as opera mista ${ }^{55}$.

$\mathrm{O}$ aglutinante mais usado em todo o aglomerado urbano é uma argamassa com base de cal e areia, possivelmente de origem fluvial, aliás já considerada por Vitrúvio

\footnotetext{
${ }^{54} \mathrm{O}$ opus incertum começa gradualmente a ser substituído em Roma nos finais da República pelo opus reticulatum, pelas vantagens que assume a sua estandardização e seriação. No entanto, a utilização deste último na Hispânia é quase excepcional, continuando o opus incertum a ser o mais divulgado. $\mathrm{O}$ opus uittatum foi também bastante utilizado em programas construtivos de algumas cidades hispanas, uma vez que era um sistema mais acessível e adequado, dentro do programa de reorganização e promoção urbanas promovidas desde o tempo de Augusto (BENDALA GALÁN, 1992: 218 e 220).

${ }^{35} \mathrm{O}$ uso de tijolos na construção é um processo relativamente tardio no século I d. C. e bastante limitado na Hispânia. Aliás, na Bética, quase não se pode falar do uso sistemático. Apenas em Munigua e em Itálica se pode falar da opção pelo uso sistemático ou, pelo menos, em grande quantidade de opus testaceum. $\mathrm{O}$ uso de tijolos é, em contrapartida, mais usual em opera mista, servindo para nivelar ou estabilizar construções (BENDALA GALÁN, 1992: 220).
} 
como a mais aconselhável, caso não existissem pedreiras (De Architectura, II, 4, 2) a que se adiciona, por vezes, uma terra argilosa ${ }^{56}$.

No forum, tendo em vista dar um aspecto mais uniforme e grandioso à praça, no paramento externo da maioria dos muros construídos em opus caementicium, que deixavam a sua face externa com um aparelho de pedras irregulares opus incertum foi utilizado quer o revestimento com estuques, quer com placas calcárias.

Algumas dessas placas calcárias (calcário fétido de S. Brissos) estão ainda in situ, como acontece no podium e nos muros que fechavam o forum do lado este e sul. No podium reconhecem-se também os encaixes onde essas placas se agarravam ao aparelho construtivo, que deveriam funcionar como lambris (ALMEIDA, 1968: 93).

Os blocos calcários eram assentes em opus signinum, técnica que é comum às termas. Só algumas das placas que a revestiriam estão ainda colocadas in situ, mas são visíveis os negativos das mesmas em quase toda a praça.

O aspecto monumental é reforçado pela sua construção em patamares, como já referimos anteriormente, cortando e aplanando a rocha para criar várias plataformas artificiais.

Esta situação é bem visível quer no lado norte do forum, onde um grande muro de contenção foi construído para vencer a diferença de alturas existente entre as duas plataformas: a mais alta onde se localiza o templo centralizado e um outro templo, ao qual se tem atribuído o culto a Vénus ${ }^{57}$ e a praça pública propriamente dita, a uma cota mais baixa. Esta situação repete-se também no declive sul do forum onde foi feito um terceiro talude em opus caementicium, a que se adossam as tabernae.

\footnotetext{
${ }^{56}$ Plínio, por sua vez, referia três tipos de areia: «a obtida nas escavações, à qual se devia juntar uma quarta parte de cal, a fluvial e a marínha, que devem misturar-se com uma terça parte de cal. Se se juntar um terço de telha picada, o produto melhora” (PLÍNIO, N. H., 36, 175, segundo edição de TORREGO, 1988: 170).

${ }^{57}$ Baseando-se na arquitectura do edifício, comum a outros templos dedicados à mesma divindade, como o dedicado a Venus Genetrix no Forum Iulium para homenagear a origem mítica dos Iulii e o de Mars Ultor (GROS, 1996: 140 e 142). Se, por um lado, a sua planta tem levantado algumas dúvidas, porque os templos basilicais são pouco usuais em edifícios religiosos, na Lusitânia, que aqui apresentam maioritariamente um aspecto rectangular (JIMÉNEZ. $1987^{1}: 53$ ), sendo mais comum o seu uso em edifícios civis, é um facto que em Itália este tipo foi muito utilizado a partir dos começos da época imperial (GROS, 1996: 140). Por outro lado, o facto de o culto a Vénus estar atestado em Miróbriga, quer arqueologicamente, através de fragmentos de uma estátua onde a deusa Vénus Capitolina é representada com a ânfora, quer epigraficamente, contribuiu para que a associação se fizesse. De facto, em Miróbriga existem duas inscrições dedicadas a Vénus a que já nos referimos: uma, cujo dedicante é Caius Iulius Rufinus, magister, indígena romanizado que adoptando o gentilício e um praenomen comum da gens Iulia, adoptou também o culto privilegiado da mesma gens (ENCARNAÇÃO, 1984: IRCP 146; ALARCÃO, 1985²: 110) e que poderá ter desempenhado funções religiosas; e outra, consagrada a Vénus Vencedora Augusta em honra de Lucília Lepidina (ENCARNAÇÃO, 1984: 224).
} 
Os taludes construídos verticalmente entre as duas primeiras plataformas usaram também opus caementicium revestido aqui, como com estuques, alguns deles pintados, como se pode inferir do negativo dos elementos decorativos feito a compasso, que se localizou junto à escadaria de acesso pelo lado oeste do templo centralizado.

Paralelamente a esse talude existe uma calçada por onde se entrava, pelo lado Noroeste, na praça pública. Esta mesma entrada dava acesso através de uma escadaria a um outro edifício de planta absidial, à qual tem sido atribuído o culto a Vénus. A orientação desta construção obedece à mesma do forum, sendo praticamente paralela ao templo centralizado.

A Poente deste templo e praticamente anexas a ele, se bem que com uma orientação diferente, existem várias construções, edificadas em opus incertum, cuja função se desconhece, porque não foram escavadas na íntegra. Deviam articular-se com as tabernae que se desenvolvem paralelamente, mas a cota mais baixa, correspondendo à plataforma por onde se fazia a entrada, pelo lado norte, na praça pública.

\section{V.2. As Tabernae}

O aspecto geral do forum e das tabernae de Miróbriga apresenta, pois, semelhanças com alguns desses fora imperiais, em que as actividades comerciais manifestam tendência para ser afastadas do forum (JIMÉNEZ, 1987²: 173; PALOL; 1987: 157; BALTY, 1993:31; KEAY, 1994: 256).

Em Miróbriga, as tabernae parecem concentrar-se junto das calçadas concêntricas se desenvolvem em volta do forum.

Apenas no declive a Sul do forum e numa das calçadas que o circunda pelo lado noroeste é óbvia a associação das actividades comerciais à arquitectura doméstica, porque é clara a existência de mais do que um piso ${ }^{58}$. Dos restantes edifícios também classificados, pelas suas características, como tabernae como é o caso dos que se desenvolvem do lado norte da calçada que desce em direcção às termas poucas ilações se conseguem tirar, porque apenas são visíveis os vestígios de muros de compartimentos unicelulares, sem aparente ligação. Em algumas dessas possíveis tabernae o pavimento era revestido a opus signinum.

Nodeclive do lado sul do forum é visível um conjunto dessas construções, obedecendo uma parte deste conjunto à orientação geral da praça. O desnível entre a praça e a rua onde desembocam algumas dessas tabernae vence-se através da edificação de um talude

\footnotetext{
${ }^{58}$ Atendendo à altura do muro de sustentação visível do lado sul do forum. e os superiores poderiam ser utilizados como áreas habitacionais.
} 
de sustentação que, paralelamente, foi utilizado como muro onde adossam essas construções. Esta situação é aliás comum às "Termas Este” (Lám. 12).

A existência de uma argola de ferro cravada e soldada numa das construções desta zona comercial tem contribuído para a relacionar com as actividades mercantis (BIERS et alii, 1981: 34).

O tipo de soleira vulgarmente usada nesta zona de Miróbriga onde não são visíveis encaixes para as portas, mas apenas uma ranhura ao longo de toda a soleira permite admitir que as tabernae seriam fechadas por tapumes de madeira movíveis que se fixam às soleiras das portas, a exemplo dos termopolia de Herculano.

As tabernae de Miróbriga são também construídas em opus incertum. No entanto, em alguns casos, na zona da fachada são usados grandes silhares aparelhados, alguns dos quais rusticados, característicos da época de Cláudio-Nero, mas cuja utilização, nas províncias, poderá ser ligeiramente mais tardia. Esta cronologia é, em Miróbriga, confirmada pelos materiais arqueológicos provenientes de uma sondagem efectuada nesta área (BIERS et alii, 1982: 36).

Numa dessas tabernae, de planta irregular, pois alarga no sentido da rua $(8,70 \mathrm{~m}$ de comprimento e $1,88 \mathrm{~m}$ de largura no topo norte e $2,58 \mathrm{~m}$ de largura na zona sul) encontra-se um silhar aparelhado com uma cabeça de touro esculpida. Localiza-se junto à escadaria que permitia, numa fase inicial, o acesso ao forum a partir da calçada ao longo da qual se desenvolvem as tabernae (ALMEIDA, 1964: 30; SOREN et alii, 1992: 37). Esta escada deve ter perdido a sua função, numa fase posterior, porque na parte superior, por onde acedia à praça púbica, foi feito um estrangulamento Fot. 10 .

O silhar esculpido é de relativamente grandes proporções (Alt. $38 \mathrm{~cm}$; comp. $92 \mathrm{~cm}$; espess. $43 \mathrm{~cm}$ ). A cabeça de touro naturalista (não se trata de um bucrânio descarnado) assemelha-se a algumas imitações dos motivos helenísticos datadas do século I a. C.. O touro ocupa um campo quadrangular de $22 \mathrm{~cm} \times 22 \mathrm{~cm}$, enquadrando-se no lado esquerdo. O bloco está fragmentado em duas partes. Deve estar fora do seu contexto (BIERS et alii, 1981: 34), uma vez que se encontra no nível térreo das construções e não tem qualquer ligante ou argamassa que o una aos próximos.

Tratando-se de um motivo decorativo com as características que tem, deveria estar implantado num lugar visível da construção a que pertencia. Não existe, noentanto, qualquer referência à sua deslocação para este local, pelo que só escavações na área poderão contribuir para um melhor conhecimento dos espaços arquitectónicos no seu conjunto. A sua cronologia deverá corresponder ao século I d. C. (BARATA: 1994: 73-77).

Nas redondezas, há outros blocos de grandes dimensões, colocados de uma forma indiscriminada, alguns deles rusticados, apontando para a existência de grandes 
construções em época claudiana ou pós-claudiana, uma vez que é nesse período que entra em moda o aparelho rusticado. Muito possivelmente estes silhares provêm das construções do forum e devem aí ter sido colocados em trabalhos arqueológicos anteriores, mas de que infelizmente não há registo. Em muitos deles são visíveis os orifícios onde se prendiam os ferrei forfices utilizados para a sua elevação.

Em frente das construções que deverão corresponder à zona mercantil de que temos vindo a falar, existe uma edificação que tem sido identificada como hospedaria ou stabulum (BIERS et alii, 1984: 48-51) pela existência de vários quartos e salas de refeições decorados com pinturas murais, datáveis de meados do século I d. C. (op. cit, loc. cit.; SOREN, 1983: 60-61; BIERS et alii, 1984: 51).

Não obstante, o designado stabulum cuja planta é só parcialmente conhecida, até porque parte desta construção, erigida junto a um grande declive, se tem vindo a desmoronar articula-se em torno de um átrio que deveria ser porticado, fazendo-nos admitir que se trate de uma domus. Efectivamente muitos dos compartimentos dessa construção datável de meados do século I d. C. são ornamentados com pinturas murais, algumas das quais foram consolidadas, protegidas e estudadas pela equipa luso-america (BIERS et alii, 1982: 38 e 1983: 60-61; 1984: 48-51). Muito recentemente, já em 1996, foi encontrado num interior de um dos compartimentos desta construção o fragmento de uma taça em terra sigillata marmoreada, cuja cronologia aponta para a época de $\mathrm{Nero}^{59}$.

\section{V.3. As Termas}

Aproveitando a depressão natural do terreno, que ajuda à captação e à concentração das águas pluviais, os romanos instalaram, numa das zonas mais baixas da cidade $\mathrm{e}$ ligeiramente afastadas da zona central ${ }^{60}$, umas termae publicae ou balnea $a^{61}$. Por terem sido edificadas nessa depressão e com as zonas aquecidas viradas a Sul concentravam o calor, como era aconselhado por Vitrúvio (De Architectura V.X.1). (Lám. 13).

\footnotetext{
${ }^{59}$ No entanto, a equipa luso-americana aponta a construção da calçada que medeia as tabernae e a edificação que designam com "south building" ou hospedaria para uma data compreendida entre 60 e 70 d.C. (BIERS et alii, 1983:63; 1984: 48-51).

${ }^{60}$ Nas Províncias Ocidentais estas estruturas situam-se normalmente na parte central dos aglomerados e são das primeiras infra-estruturas construídas nos mesmos, datando, na grande parte, dos séculos I-II d. C. (NIELSEN, 1990: 91-92. I).

${ }^{61}$ Segundo NIELSEN, 1990: 3 e MAR, 1994: 285 poderão tratar-se de balnea. O conceito de Balnea é utilizado por Nielsen como tratando-se de edifícios de estrutura dupla, contemplando a separação por sexos, e sem palestra, muito possivelmente de uso público, mas de exploração privada (BARRIENTOS, 1997: 267). De notar, no entanto, que o complexo de Miróbriga tem grandes dimensões, e ocupa um espaço superior às insulae, podendo ter possuído uma palestra. Poderia contemplar, não obstante, o balneum muliebre e o balneum virile.
} 
Composto por dois edifícios ${ }^{62}$, de construção não muito distante no tempo e que se adossam, maximizando, desse modo, algumas das suas infra-estruturas, este complexo duplo foi edificado na zona sudoeste do aglomerado urbano, ocupando as estruturas actualmente postas a descoberto uma área aproximada de $1.100 \mathrm{~m}^{2}$ (Lám. 14).

Os edifícios que as compõem são: as "Termas Este", as primeiras a ser edificadas no século I d. C. ${ }^{63}$ e que sofreram várias ampliações nessa centúria; e as "Termas Oeste", que foram construídas posteriormente, a partir da segunda metade do século II d. C. (BIERS et alii, 1988: 111).

No entanto, alguns dos elementos escultóricos das "Termas Oeste", colocam-nos algumas dúvidas em relação às cronologias atribuídas a este edifício, nomeadamente o capitel «corintizante com influências da ordem compósita» ${ }^{64}$, que combina volutas vegetais próprias dos capitéis corintizantes ${ }^{65}$ com elementos decorativos próprios dos compósitos (BIERS et alii, 1988: 199-201), como são os óvulos e os dardos.

A equipa luso-americana que trabalhou em Miróbriga inclina-se a datar este elemento arquitectónico entre o finais do século I (BIERS, 1983: 40; BIERS, 1985: 40) e o século II d. C. (BIERS et alii, 1988: 199-201).

Entretanto, outros elementos arquitectónicos, como os capitéis coríntios de pilastra de folhas lisas, apontam para uma construção situada em meados do século I d. C., a exemplo dos espécime existentes no forum flaviano de Conímbriga (BIERS, et alii, 1985: 40; 1988: 201-202; ALARCÃO e ETIENNE, 1977: 104) ${ }^{66}$. A utilização de silhares rusticados na entrada, em moda a partir dos reinados de Cláudio e Nero

Segundo P. Gros o termo Balnea é utilizado para edifícios que podendo ser igualmente importantes, são, não obstante, menos complexos ou monumentais do que as Thermae (GROS, 1996: 389). Atendendo a estas definições, consideramos mais correcto considerar-se o complexo de Miróbriga como tratando-se de Balnea. Segundo Yegül as principais diferenças entre termae e balnea residem exactamente na escala e na propriedade dos edifícios, sendo as primeiras genericamente de maiores dimensões e estatais, e os segundos de menor tamanho e privados (YEGÜL, 1995: 43).

${ }^{62}$ Estes edifícios foram objecto de bastantes trabalhos arqueológicos tendo a planta mais pormenorizada dos mesmos sido publicada pela equipa americana, que dedicou ao complexo e aos materiais arqueológicos aí exumados grande parte da sua edição (BAR, 1988) e que avançou com uma tentativa de reconstituição para a zona de entrada das "Termas Oeste".

${ }^{63}$ A equipa americana atribuiu uma remodelação das “Termas Este” ao século II d. C. No entanto, nas sondagens efectuadas nas "Termas Este" foram encontradas cerâmicas datáveis do século I, da época flávia (BIERS, 1984: 46), correspondendo aos níveis mais antigos dessa construção.

${ }^{64}$ Trata-se do capitel que foi colocado por D. Fernando no templo centralizado.

${ }^{65}$ Em Mérida são bastante comuns os capitéis corintizantes com volutas vegetais (BARRERA, 1984).

${ }^{66}$ Da Alcazaba de Mérida existe, contudo, um exemplar $\left(n^{\circ} 84\right)$ que tem bastantes semelhanças com o de Miróbriga e que foi datado de meados do século II d. C. (BARRERA, 1984: 56). 
(MARTA, 1991: 14), fazem-nos admitir uma cronologia mais antiga para a sua edificação, que se deverá ter efectuado ainda durante o século I d. C.

Um estudo tipológico de termas considera as termas de Miróbriga entre as de "simple ring type" (NIELSEN, 1990, C.119: 71, I e 17, 63 e 127, II), uma vez que não se verifica qualquer eixo que defina a edificação simétrica dos compartimentos ou das piscinae do frigidarium ${ }^{67}$.

As "Termas Este", construídas a uma cota mais baixa, são acessíveis por uma calçada muito íngreme que serve os dois edifícios.

Várias situações de articulação entre os dois edifícios, nomeadamente toda a estrutura dos esgotos, fazem-nos admitir a hipótese de que os mesmos possam ter tido um projecto contemporâneo.

As "Termas Este" estão como que praticamente encravadas na rocha e para a sua construção foi necessário escavar e/ou aplanar o afloramento xistoso. Esta situação é bem visível no lado norte das termas onde se cortou a rocha para a construção do edifício, fazendo-se depois um muro de grandes dimensões que serve, paralelamente, de talude de contenção e de apoio à obra, porque a ele se adossam outros muros e compartimentos do balneário. Junto a esse talude edificado, a uma cota um pouco mais baixa, os romanos construíram uma canalização em opus signinum para escoar as águas pluviais e um muro paralelo ao referido talude, onde devia assentar o telhado.

Este edifício é de menores dimensões do que as "Termas Oeste", ocupando, no entanto, uma área maior do que a actualmente posta a descoberto (aprox. $400 \mathrm{~m}^{2}$ ), como aliás é fácil concluir da sua planta e dos muros que afloram junto ao talude do lado sul.

A entrada nas "Termas Este" faz-se descendo inicialmente dois degraus, que se situam junto aos que conduzem às "Termas Oeste". Continua-se a descer através de uma calçada em declive, porque este edifício se situa a uma cota mais baixa do que a construção a ela adossada, até à porta de entrada.

Através desta porta acedia-se, através de dois degraus revestidos a opus signinum a uma zona porticada coberta que deveria circundar uma pequena palestra (?). $\mathrm{O}$ pavimento era também aí revestido com opus signinum, ainda praticamente intacto em vastas áreas. À volta dessa zona porticada há um corredor que, inflectindo para o lado sul das termas, dá acesso a um compartimento de funcionalidade desconhecida e a outros que ainda não foram escavados, sendo também visíveis, em alguns pontos, os muros que deveriam servir de limite ao edifício.

\footnotetext{
${ }^{67}$ Ao contrário do que acontece nas termas de Trajano em Conímbriga, que são axializadas (ALARCÃO e ETIENNE, 1977, I*: 131), ou nas de Tongobriga, desenvolvidas segundo um eixo (DIAS. 1997: 35).
} 
Do seu lado norte, desenvolve-se um longo compartimento que conduzia, quer às zonas aquecidas, quer ao frigidarium e respectiva piscina. A todo o comprimento desse compartimento, com funções de apodyterium, existe um banco revestido $a$ opus signinum, utilizado pelos utentes das termas. Este longo corredor era decorado com frescos, como ainda se pode verificar em alguns pontos, designadamente junto do compartimento circular a que nos referiremos de seguida.

Do lado esquerdo da entrada havia, portanto, uma construção circular, localizada a uma cota ligeiramente mais alta do que o pórtico, que deveria tratar-se também de um compartimento com funções de apodyterium (BIERS, 1988: 85). Este compartimento era selado por uma porta, à qual se acedia através de um degrau.

Do apodyterium alongado poderia passar-se directamente ao frigidarium e à piscina. Ainda revestida, na sua parte inferior, com opus signinum apresenta, superiormente, uma decoração com pinturas a fresco.

Do lado sul do frigidarium havia uma porta por onde se entrava no tepidarium $\mathrm{e}$ no caldarium. Nestes compartimentos providos de hipocaustum com suspensurae, existem três alvei.

As "Termas Oeste", em melhor estado de conservação, têm uma forma rectangular e se bem que não totalmente escavadas, podem ser consideradas como um dos bons exemplos dos balneários das províncias ocidentais.

O edifício foi construído quase na íntegra em opus incertum e apresentava na fachada, mais cuidada, grandes silhares rusticados, cuja utilização parece apontar para o período neroniano ou pós-Nero.

A entrada fazia-se descendo três degraus, que permitiam aceder a uma cota inferior. Nas extremidades do primeiro degrau havia «três altas colunas cilíndricas, de fino mármore, uma delas nichada» (SILVA, 1945: 344), com capitéis corintizantes em calcário fétido de $\mathrm{S}$. Brissos. Nenhuma destas colunas se encontra actualmente in situ, tratando-se das que foram levadas por D. Fernando de Almeida para o forum.

À frente dos degraus de entrada dos balnea localizava-se também uma porta de grandes dimensões, como se pode concluir pela soleira ainda in situ, onde ainda recentemente foi encontrado um fragmento dos elementos metálicos que revestiam o sítio onde girava o eixo da couceira.

Era através desta porta que se acedia a uma ampla sala de entrada ou uestibulum, que tinha em anexo dois compartimentos mais pequenos, possivelmente com funções de apodyteria ${ }^{68}$.

${ }^{68}$ Cruz e Silva admitia que um deles, localizado do lado esquerdo de quem entra nas termas, se tratava do elaeothesium, destinado a «massagens simples ou com óleos» (SILVA, 1945: 347). 
O pavimento do uestibulum era revestido com placas de calcário e possuía lambris a toda a volta, situação que é praticamente comum a todo o edifício. Em algumas salas são visíveis os negativos em opus signinum onde as placas eram colocadas na horizontal, bem como os orifícios onde entravam os espigões que as prendiam. Por sua vez, as ombreiras das portas e algumas soleiras eram revestidas de calcário fétido de S. Brissos.

A meio do uestibulum está tombada uma coluna duplicada ou geminada de grandes dimensões, também de calcário de S. Brissos.

Nessa sala, edificada em opus incertum, foram também utilizados grandes silhares aparelhados junto à ombreiras das portas, nomeadamente as que ligam o uestibulum aos apodyteria e ainda ao frigidarium. Esses grandes silhares, que marcavam alguns dos ângulos do edifício, ou cunhais ${ }^{69}$, eram também revestidos, porque são visíveis os orifícios onde eram presas as placas nas ombreiras. Estes compartimentos deveriam eram decorados com frescos.

Depois do uestibulum acedia-se através de duas entradas ao frigidarium. Este compartimento tem uma forma rectangular, existindo nos topos duas piscinae, uma, como que formando um nicho, e outra, bastante mais funda, de forma praticamente quadrangular ${ }^{70}$, que quase se poderia tratar de uma pequena natatio (NIELSEN, 1990: 155). Nessa piscina existiam degraus interiores, que deveriam ser parcialmente submersos $^{71}$, e um sistema de escoamento para a latrina. Dessa sala havia uma passagem para um compartimento que se desenvolvia a Este com um hipocausto com suportes verticais pilae, que possivelmente se trataria de um sudatorium com ligação directa ao praefurnium.

Posteriormente passava-se ao tepidarium, dotado de suspensurae e hypocaustum construído com arcos de tijolos argamassados e ainda salas dotadas de paredes duplas ${ }^{72}$, edificadas em opus testaceum.

${ }^{69}$ Como acontece em Conímbriga (ALARCÃO e ETIENNE, 1977, I*: 114) e em Tongobriga (DIAS, 1997: 165 e 169)

${ }^{70}$ Em Segobriga existe uma sala com funções de frigidarium com uma natatio na zona central que é um bom paralelo para a de Miróbriga. De notar que também aí o sistema de escoamento era bastante eficaz (ABASCAL, 1997: 39-41.)

${ }^{11}$ A exemplo do que acontecia no frigidarium de Tongobriga (DIAS, 1997: 167 Estampa 4). Na maioria dos balneários do Norte de África, a natatio é uma piscina interior de grandes dimensōes localizada no frigidarium que difere, portanto, do tipo de natatio a céu aberto, comum nas termas imperiais (YEGÜL, 1995: 408). De salientar que em Miróbriga foi parcialmente escavado um grande tanque que deveria tratar-se de uma natatio descoberta.

${ }^{72}$ Em Roma o opus testaceum é usado vulgarmente a partir de Tibério, adquirindo quase um carácter oficial (ROLDÁN GÓMEZ, 1987²: 36). Na Península a sua utilização é tardia, sendo mais comum a partir da época flávia. Foi usada mais profusamente nos edifícios termais. Mais comum é a utilização do opus mistum, que na Hispânia se vulgariza mais cedo do que o opus testaceum. 
O caldarium, de forma praticamente quadrangular, tinha dois alvei de diferentes dimensões, sendo o de topo absidiado, dada a necessidade de concentrar o vapor e o ar quente necessários. Ambos os alvei apresentam no fundo canos de chumbo que escoavam para o sistema de evacuação das termas. O caldarium estava virado a Sudoeste para aproveitar o calor da tarde. A Este situava-se o praefurnium e as áreas de serviço.

As suspensurae das zonas aquecidas assentavam nos arcos do hipocausto. O pavimento de circulação dos utentes era revestido com opus signinum, sobre o qual foram colocadas lajes calcárias. Entre os arcos e o opus signinum ainda existem, in situ, imbrices de grandes proporções, que permitiam, por um lado, uma melhor circulação do ar aquecido e, por outro, um melhor apoio para o pavimento. $O$ chão do hipocausto utilizava também tijolos rectangulares.

Algumas das salas absidiadas do tepidarium e do caldarium tinham janelas viradas a Poente para um pátio ou pequena palestra (?) que circundava desse lado o edifício, permitindo o arejamento das salas aquecidas. Ao pátio, que eventualmente teria uma função semelhante a um solarium, dada a sua localização, podia-se aceder apenas pelo interior do edifício, através de uma porta existente a Noroeste do uestibulum. Esta porta apresenta características construtivas diferentes das outras aí existentes, pelo que possivelmente não pertenceria à fase inicial da obra (BIERS, 1983: 47). O acesso faziase vencendo um degrau de uma altura relativamente elevada.

O pátio, pavimentado a opus signinum, desenvolvia-se até ao muro que delimitava a Oeste as termas, numa situação de algum modo semelhante ao que acontecia nas "Termas Este". As arestas interiores eram revestidas com meias canas salientes. Uma conduta subterrânea, paralela à que existe do lado nascente das "Termas Oeste", corria ao longo desse pátio, sendo ainda visíveis alguns dos seus respiradores.

Como já anteriormente referido, a maioria dos compartimentos das "Termas Oeste" era revestida de placas calcárias, quer no pavimento, quer nas paredes, permitindo uma fácil manutenção do edifício. As placas eram fixadas à parede através de "gatos" metálicos como ainda recentemente, em acção de consolidação e restauro na piscina do frigidarium das "Termas Oeste" se pôde verificar. Teríamos, pois, os muros construídos em opus incertum, com revestimento a opus signinum, no qual eram presas as placas calcárias com espigões de cobre ou de bronze.

Uma latrina, implantada nas "Termas Oeste", a que se acede através de um corredor em forma de L logo à entrada do complexo, pode, segundo a equipa luso-americana ter servido simultaneamente os dois edifícios, após a construção deste último. Esta hipótese parece-nos difícil de aceitar se admitirmos que os dois edifícios servissem diferenciadamente os dois sexos. Muito possivelmente, nas "Termas Este", onde uma concentração de alfinetes de cabeça em alguns compartimentos parece indiciar uma 
utilização mais feminina (BIERS et alii, 1988: 115), poderia haver outras latrinas. É de salientar, no entanto, que as latrinas localizadas nas "Termas Oeste" eram fechadas por uma porta, como o comprova a existência de uma soleira que ainda se encontra in situ, à sua entrada.

Num dos cantos do compartimento onde se encontram as latrinas existe o negativo de um pequeno reservatório com saída de águas que dão para o sistema de evacuação geral das termas. O citado reservatório poderia servir para as abluções, a exemplo do que acontecia em Óstia, nas termas do forum, (ADAM, 1989: 278) ou para guardar os instrumentos com que se faziam algumas limpezas higiénicas.

Quer nas "Termas Este quer nas "Oeste" parece atestar-se o percurso de utilização frigidarium-tepidarium-caldarium, reconhecido em inúmeros balneários romanos ${ }^{73}$.

Em 1996 foi parcialmente posto a descoberto, sob os empilhamentos de pedras de anteriores escavações, um reservatório construído em opus incertum e revestido interiormente com opus signinum, com meias canas nas arestas do fundo, para permitir que o mesmo fosse totalmente estanque. Edificado num ponto alto, por cima do local onde se adossam os dois complexos termais, devia garantir o abastecimento temporário de água às termas. Possivelmente este reservatório seria coberto, para garantir a limpeza da água e dificultar a evaporação da mesma (YEGÜL, 1995: 390). Esta solução de tanques elevados, opera signina, é comummente utilizada, sendo aliás recomendada por Vitrúvio, bem como o recurso a poços putei e cisternas (De Architectura VIII, I,17 e VIII, VII, 13 e14).

Uma cisterna construída em patamares, de secção quadrangular, pavimentados com lajedos e paredes em alvenaria argamassada, serviria possivelmente para decantação das águas pluviais (ou as águas de alguma mina hoje seca) e poderia colaborar no escoamento das termas. A água era depois conduzida por um canal subterrâneo abobadado, construído em pedra calcária, que posteriormente se dividia em vários ramais que circundavam todo o complexo termal Oeste e Este e que evacuavam para uma cloaca, ainda visível junto à ponte.

Para esse sistema de evacuação eram também despejadas as águas de várias das piscinas ou alvei das termas. Esse escoamento fazia-se através de canos de chumbo ${ }^{74}$ que ainda se encontram in situ no interior dos alvei do caldarium e na piscina ou natatio do frigidarium das "Termas Oeste".

\footnotetext{
${ }^{73}$ De que as termas flavianas de Tongobriga são um exemplo entre tantos (DIAS, 1997: 36).

${ }^{74}$ Vitrúvio preconizava também a utilização de condutas de chumbo (De Arch. VIII, VI, 21 e 25-34)
} 
O fornecimento de água deveria ser, contudo, reforçado por uma fonte existente nas proximidades, como se pode deduzir pelo canal que permitia a adução da água pelo lado sul do reservatório ou natatio (?) cuja escavação se iniciou em 1992.

A natatio (?) era construída em opus incertum revestido de opus signinum, com várias camadas. No fundo da mesma existe também uma meia cana saliente.

Não são conhecidas actualmente quaisquer nascentes localizadas a Sul das termas, que pudessem permitir o enchimento dos reservatórios. A única mina de água que ainda é actualmente utilizada situa-se na área limítrofe a Miróbriga, a Nascente da ponte.

Nas proximidades das termas, existe uma ponte de um só arco quase perfeito, construída em opus incertum, também com pedra calcária, aparentemente regularizada por fiadas de xisto. Esta construção deveria permitir a articulação entre esta zona e a área residencial a Noroeste, através de uma calçada de que só se conhecem alguns vestígios, até porque ainda funciona parcialmente como caminho (Lám. 15).

\section{V.4. A Estrutura viária e as habitações}

Pelas características peculiares do urbanismo de Miróbriga, não é possível visualizar qualquer resquício de uma malha urbana definida por eixos viários principais cardo e decumanus, como é comum nas fundações latinas de plano ortogonal. No entanto, os arruamentos conhecidos permitem-nos delinear o espaço ocupado por algumas das insulae da cidade onde se instalam aedificia privata e definir os percursos de acesso a alguns dos seus núcleos polarizadores, como é o caso das opera publica conhecidas em Miróbriga o forum e as termas.

O forum deveria ser circundado por uma rede viária que constituía como que uma espécie de "circunvalação", permitindo o crescimento do casario em anéis concêntricos (ALARCÃO, 1990: 465) que, a alguns níveis, mais lembram algumas malhas urbanas medievais. As longo dessas calçadas e entre elas desenvolviam-se os quarteirões onde se implantavam as áreas comerciais e habitacionais.

Uma ampla calçada estrutura uma área habitacional, que se desenvolve quer para Norte quer para Sul da mesma. Do lado sul constata-se que as casas se adaptam à pendente e que os desníveis são vencidos através de grandes escadas que permitem o acesso pedonal à via. Muito possivelmente, a uma cota mais baixa, se desenvolveria uma outra via que poderia fazer a ligação, mais a Sul, às termas.

Continuando pela via inicialmente referida, na direcção do forum, chega-se a um ponto onde a via se ramifica, permitindo, por um lado, o acesso ao mesmo e aos quarteirões que se desenvolviam do seu lado norte e ainda às termas, a Sul. 
Junto às termas verifica-se um caso semelhante de bifurcação, porque, por um lado, a calçada acede directamente aos balnea e, por outro, inflecte no sentido de Nordeste, onde poucos vestígios restam, mas que deveria articular uma segunda plataforma que circundava, do lado sul e este, o forum.

Junto às tabernae que se desenvolvem a Sul do forum, vencendo também uma enorme pendende, é visível uma calçada que, também ela deveria fazer uma circunvalação à zona central da cidade.

Todos os troços de calçadas conhecidos em Miróbriga são construídas com grandes lajes assentes directamente no afloramento xistoso ou sobre o solo, e carecem de qualquer tratamento para a sua colocação ou seja statumen e rudus. Medem, em média, aproximadamente 10/11 pés de largura. Em alguns pontos, as calçadas apresentam rebordos laterais isolados com opus signinum, nomeadamente na que desce em direcção às termas. Julgamos que a sua funcionalidade poderá ser a de contribuir para a impermeabilização na zona da entrada ${ }^{75}$ das tabernae e habitações, que se situam ao longo desta via em pendente. Dos vestígios conhecidos, não se consegue inferir da existência, sob o opus, de canalizações de evacuação laterais em materiais cerâmicos ou outros ${ }^{76}$.

Noutros casos, ao longo das calçadas, foram construídas as condutas dos esgotos em opus incertum pavimentadas com lateres, como acontece junto à "área habitacional", perto da actual entrada das ruínas, e do lado sudoeste do forum, onde apenas restam alguns vestígios da via pública. Estes esgotos deveriam ser cobertos, possivelmente com laterae ou tegulae, mas não existem quaisquer vestígios dessas coberturas.

Com alguma certeza apenas se conhecem algumas habitações das muitas que devem ter existido no núcleo urbano de Miróbriga. No entanto, são visíveis, de um lado e do outro da calçada que se encontra logo à entrada actual das ruínas, várias insulae, com uma ocupação sucessiva entre o século I d. C. e IV d. C.

Apesar do conhecimento incipiente das zonas habitacionais que se desenvolvem nessa área, pode-se verificar que as insulae são de métricas diferentes, em função das ruas e acessos públicos, variando entre 25 a $30 \mathrm{~m}$. As escadarias edificadas a Sul da via anteriormente referida delimitam claramente insulae, em torno das quais se pode ainda ver o respectivo sistema de esgotos.

Algumas destas construções tinham água canalizada, como se pôde verificar aquando dos trabalhos de limpeza e de restauro efectuados na "casa com frescos", do lado direito

\footnotetext{
${ }^{75}$ A exemplo do que se verifica em Itálica (LUZÓN NOGUÉ, 1982: 94, fot. 3)

${ }^{76}$ Como por exemplo acontece em Pompeios (ADAM, 1989: 259).
} 
da calçada. Junto à entrada havia um pequeno tanque, possivelmente de aprovisionamento de água que era conduzida por uma tubagem de chumbo (Lám. 16).

A Este desta construção, ao longo da via, quer do lado norte quer do Sul da mesma, são visíveis vários muros dispersos, devendo tratar-se de habitações. No entanto, como todos eles foram postos a descoberto, em anteriores trabalhos arqueológicos, através de valas abertas paralelamente aos mesmos, nada se pode concluir, porque nenhuma planta está clarificada.

Mais a Oeste, do lado norte da via, iniciámos recentemente uma escavação numa área que já havia sido parcialmente assinalada pela equipa luso-americana, e que veio a revelar a existência de uma domus, cujos compartimentos se desenvolvem em torno de um átrio. Este átrio tinha uma zona coberta, como o comprovam a concentração de telhas no local e os entalhes definidos no afloramento xistoso que deveriam servir para apoiar o telhado.

O pavimento da zona circundante do átrio era revestido a opus signinum, ainda visível em alguns pontos. $\mathrm{Na}$ zona central, subdividida num segundo momento da ocupação da casa, deveria ter existido uma zona ajardinada.

Os pavimentos das salas que se desenvolvem em seu redor deveriam ser feitos com traves de madeira, pois não existe qualquer vestígio de revestimento e o afloramento xistoso é bastante irregular, o que aliás deveria acontecer em muitas das residências localizadas nesta área. A evidência de vários buracos circulares escavados no xisto, na residência que escavámos, assemelhando-se a "buracos de poste", mas distribuídos sem qualquer aparente regularidade, contribuem para colocar esta hipótese. Numa destas concavidades estava perfeitamente conservada, ao nível da rocha de base, que foi escavada para o efeito, a tacinha com ossos a que fizemos referência no início deste trabalho.

Num dos compartimentos paralelos à calçada, à entrada da casa, e que possivelmente se trataria de uma oficina de metalurgia ${ }^{77}$, até porque existe uma grande concentração de escória de ferro, detectámos, por cima do afloramento xistoso, uma conduta construída com imbrices encaixados uns nos outros, que escoava para a rua. Essa conduta passava por debaixo de um dos muros que definem o limite sul da casa, junto à soleira da porta de entrada.

Os materiais arqueológicos entretanto exumados nesta domus atestam uma ocupação que vai do século I ao século IV d. C., tendo mesmo sido encontrado um numisma republicano.

${ }^{77}$ Em Tongobriga foi também detectada no interior de uma construção uma oficina de metalurgia (DIAS, 1997: 79). 
A casa por nós parcialmente escavada poderia ter dois pisos, porque se adossou, do lado oeste, uma escada, que deveria dar também serventia às construções que se desenvolvem num plano mais elevado, a Noroeste da habitação.

Entre a calçada, que se desenvolve a Sul, e a soleira da porta de entrada da "construção de átrio", existe um pavimento em opus signinum, desaparecido em grande parte, que permitia um acesso mais confortável e higiénico à mesma. Era junto a esta zona que desaguavam as águas canalizadas pela conduta de imbrices anteriormente referida.

É de salientar que a planta da casa em escavação é paralela à da capela de S. Brás, edificada, a Noroeste, ao lado e sobre estruturas romanas, devendo pertencer ao mesmo programa urbanístico. Os restos destas habitações pertenceriam, portanto, a um conjunto residencial mais vasto que se estendia do lado norte da calçada, adaptando-se ao declive natural do terreno (vide Lám. 1).

Numa área recentemente adquirida, a Oeste da actual entrada de Miróbriga, iniciaram-se, em 1997, trabalhos arqueológicos, tendo-se aberto algumas sondagens para averiguar da possibilidade de aí ser construído o "Núcleo Interpretativo". À superfície foi encontrada uma moeda de Marco Aurélio e, já pertencente a um nível arqueológico bem selado, de fundação de algumas construções, foi encontrado um outro, cunhado em Mérida no reinado de Augusto.

Se bem que sendo ainda demasiado precoce fazer afirmações sobre esta zona, é um facto que os muros que começam a aflorar deverão pertencer a construções articuladas com a "área residencial", pois parecem obedecer à mesma orientação do que as casas localizadas na área limítrofe da capela de S. Brás. Junto a uma dessas construçōes em fase de escavação, detectou-se uma enorme concentração de escória, associada a uma terra barrenta que foi sujeita a alta temperatura, porque se encontra cozida, como se de terracota se tratasse. Possivelmente, tratar-se-ia, também, de uma zona onde existiam ateliers metalúrgicos.

Pelo numisma anteriormente referido, pode apenas deduzir-se que a ocupação desta área do oppidum romanizado se deverá ter processado desde bastante cedo, não conferindo, portanto à zona onde foi implantado o forum (o único local onde apareceram in situ materiais da Idade do Ferro) o papel único de polarizador de crescimento em período de Miróbriga, pois a intervenção monumental parece ser mais tardia.

\section{5. O Hipódromo ou Circo}

Uma vez que os lugares de espectáculo, tais como os teatros, os anfiteatros e os circos foram, nas províncias, uma das formas utilizadas para facilitar o processo de 
Romanização, pois incentivavam as deslocações periódicas dos rurais à cidade (ALARCÃO, 1992: 60), sendo ainda os locais ideais para a expansão da mística imperialista $^{78}$ (GROS; 1994: 22) não é, portanto, de estranhar que exista uma associação entre a edificação de um hipódromo em Miróbriga e o culto imperial ${ }^{79}$.

A construção de um hipódromo ou circo ${ }^{80}$ em Miróbriga deve ter obedecido aos mesmos princípios, contribuindo para consumar a ideologia imperial. Não foram, contudo, identificados quaisquer evergetas que possam ser (co)financiado a sua edificação, desconhecendo-se também o papel que as elites locais possam ter desempenhado na construção de qualquer outra obra monumental. Apenas uma inscrição com invocatória a Esculápio, a que já nos referimos, atesta um legado testamentário feito por um medicus pacensis, Gaio Átio Januário, que deixou dinheiro ao conselho municipal para que organizasse os quinquatrus (ENCARNAÇÃO, 1984: 218).

O hipódromo de Miróbriga dista aproximadamente $1 \mathrm{Km}$ em linha recta da zona central do aglomerado urbano, como acontece em muitos locais de espectáculo com estas características, que são afastados por motivos práticos ${ }^{81}$ o circo de Mérida é disso um bom exemplo, a $400 \mathrm{~m}$ do teatro e anfiteatro ou ainda projectados para fora do núcleo urbano inicial tendo em vista polarizar uma nova área de crescimento urbano, como se verifica em Saguntum (ARANEGUI, 1994: 74).

O acesso ao hipódromo de Miróbriga deveria fazer-se através de uma fachada que se localizava frontalmente em relação a uma das estradas de saída do aglomerado

\footnotetext{
${ }^{78}$ A realização dos ludi é indispensável ao desenvolvimento dos Sacra Augustalia (GROS, 1994: 27) Muitos dos edifícios monumentais do Império devem-se mesmo à intervenção directa do imperador, que, por seu lado, estimulava a participação das elites urbanas locais nas construções de grandes obras públicas, através de donativos. De Balsa, no actual Algarve, temos notícia epigráfica da existência de um circo, cuja construção se deve parcialmente a dois evergetas G. Licinius Badius e L. Cassius Celer. Vasco Mantas apresentou uma hipótese para a sua localização através de foto-interpretação (MANTAS, 1997: 292), se bem que ainda esteja sujeita a uma confirmação no terreno.

${ }^{79}$ Como aliás acontece em Tarragona.

${ }^{80}$ Usamos aqui os dois conceitos baseando-nos na definição apresentada por GROS, 1996: 346. «No caso do hipódromo grego o que conta é a pista...; se bem que o espectador não seja excluído, mas o espaço não é organizado em função da sua presença. Em Roma, pelo contrário as instalações essenciais foram desde cedo concebidas para o espectador: as bancadas que envolvem a pista definem o próprio edifício e as infra-estruturas, cada vez mais desenvolvidas, do circus tinham como finalidade melhorar a qualidade do espectáculo».

No caso de Miróbriga o facto de nada indiciar a existência de bancadas laterais monumentais pode fazer-nos admitir que se trate de um lugar de espectáculo que mais se aproxima da ideia do hipódromo grego.

${ }^{81}$ Ao contrário do que acontece com o circo de Tarragona, situado na zona central da urbs. A sua localização tem intrigado muitos investigadores, sendo justificada pelo facto de se tratar do terceiro componente do «santuário provincial de culto imperial» (GROS, 1996: 352).
} 
urbano $^{82}$, ligando-o a Alvalade do Sado onde, como já referido, existem inúmeros vestígios romanos. Justifica-se, desse modo, o facto da entrada se fazer de costas viradas para o centro da cidade.

Podendo considerar-se um recinto de média proporção $0^{83}$, apesar de não apresentar um aspecto monumental ${ }^{84}$ é inferior ao de Mérida que, construído em inícios do século Id.C., mede 417,30m de comprimento por 112m de largura (SÁNCHEZ, 1997: 245) e ao de Todelo, datável entre o final da dinastia Julio-Cláudia, cuja arena mede $408 \mathrm{~m}$ de comprimento e 86m de largura (SÁNCHEZ-PALENCIA, et alii, 1988: 25), a arena de Miróbriga é, contudo, de maior dimensão do que a do circo de Tarragona $290 \mathrm{~m} \times 67 / 77 \mathrm{~m}$ localizado no centro da cidade e datado da dinastia flávia (DUPRÉ, 1990: 319; AQUILUÉ et alii, 1991: 79). Mede aproximadamente $359 \mathrm{~m}$ de comprido por $77,5 \mathrm{~m}$ de largo.

O hipódromo ou circo de Miróbriga está orientado $\mathrm{NE} / \mathrm{SW}^{85}$, orientação que é considerada a conveniente para não ofuscar os agitadores ou aurigae a qualquer hora do dia (SANCHEZ-PALENCIA, et alii, 1988: 16) e a sua implantação foi certamente condicionada pela topografia do local, que aqui é incomparavelmente mais plano do que o sítio onde se cresceu o aglomerado urbano, e ainda pelos ventos dominantes (ENCARNAÇÃO, 1994: 13).

Do hipódromo conhecem-se as fundações da spina, construída em opus caementicium, e os limites da arena. Pesem os restauros e reconstituições parcelares aí efectuadas, é clara a evidência de metae meta prima e meta secunda. Aproximadamente a meio da spina, as fundações interrompem-se ao longo de $7 \mathrm{~m}$. Não são bem conhecidos os motivos dessa interrupção (BIERS et alii, 1981': s/p), se bem que se possa admitir que aí teria sido implantado algum elemento escultórico dedicado a uma divindade ou ao culto imperial, ou que estivesse dividida em vários segmentos, à maneira de euripus, como é comum em numerosos circos romanos, amplamente decorados com esculturas e obeliscos, como acontece em Mérida (SÁNCHEZ-PALENCIA, et alii, 1988: 20; BARROSO e MORGADO, 1997: 30). Ainda é visível o revestimento que era utilizado em grande parte da spina, tratando-se de opus signinum, a exemplo do que sucede no circo de Mérida e no recentemente posto a descoberto de Olisipo.

\footnotetext{
${ }^{82}$ Em Tongobriga foram dados a conhecer vestígios identificados um circo localizado fora da cidade, localizados junto à estrada que ligaria Tongobriga à ponte sobre o rio Tâmega, com cerca de $148 \mathrm{~m}$ de comprimento e 64m de largura (DIAS, 1997: 32).

${ }^{83}$ Os circos do século I d. C. tinham à volta de $300 \mathrm{~m}$.

${ }^{84}$ Em África os circos monumentais são relativamente tardios, não existindo qualquer exemplar anterior ao século II d. C. (GROS, 1996: 354). Por seu lado, Arles, de fundação pré-romana, tem com Augusto o primeiro plano ortogonal. Novamente sujeita a uma reforma urbana em período flaviano, é edificado o circo por volta de 149 (SINTES, 1996: 15).
}

${ }^{85}$ Como o de Toledo (SÁNCHEZ-PALENCIA, et alii, 1988: 16). 
Os muros que delimitam a arena são simples, construídos em opus caementicium, variando a sua grossura entre 60 a $90 \mathrm{~cm}$ (pé de $30 \mathrm{~cm}$ aprox.). As diferentes grossuras dos mesmos permitiram à equipa luso americana admitir que o hipódromo tivesse várias fases de construção, sobrepondo-se as paredes mais grossas a outras mais estreitas e anteriores (BIERS, 1988: 41). A sua construção deve datar do século II d. C. e o auge da sua utilização deve ter correspondido ao século III d. C., seguida do seu declínio a partir de finais dessa centúria (op. cit.: 36 e 43).

No lado sul do circo situam-se algumas construções identificadas como carceres $^{86}$ (BIERS et alii, 19812: 36-38 e 41).

De bancadas perenes ou pétreas bem como do derrube das mesmas não existem quaisquer referências ou vestígios arqueológicos. Pode admitir-se, portanto, que fossem construídas de madeira, suportadas por postes feitos do mesmo material (ALARCÃO, 1989: 245), de que não foram encontrados ainda os negativos de fundação, mas tal poderá dever-se ao facto de o local não ter sido extensivamente escavado. Nunca poderiam, contudo, ter tido a monumentalidade das reconhecidas em circos da Hispânia (GROS, 1996: 351 e 352).

Nem nos trabalhos arqueológicos anteriores, nem em limpezas de superfície efectuadas recentemente em Miróbriga se detectou qualquer indício de pavimento cimentício na pista, que deveria ser térreo. Uma camada de terra muito escura e compactada é, contudo, visível ao longo da pista.

Há que salientar, no entanto, que o hipódromo foi sujeito, ao longo de tempo, a vários tipos de ameaça. Por um lado, a necessidade de materiais de construção, nomeadamente para a edificação do castelo, em período medieval, poderá ter contribuído para uma devastação deste lugar de espectáculoe, por outro, os trabalhos agrícolas que se efectuaram até data recente data contribuíram também para a sua destruição ${ }^{87}$ - (Lám. 17).

\section{6. As Necrópoles de Miróbriga}

Até muito recentemente não era conhecida qualquer sepultura ou necrópole associada a Miróbriga, se bem que um achado vítreo encontrado numa sepultura junto da aldeia das Formiga, datável do século I d. C. (ALARCÃO, 1968: 29), junto a uma das saídas que possivelmente haveria de Miróbriga com ligação ao Cercal e a Alvalade do Sado, e

\footnotetext{
${ }^{86}$ Como acontece no circo de Toledo (SÁNCHEZ-PALENCIA, et alii, 1988: 18).

${ }^{87} \mathrm{D}$. Fernando de Almeida diz textualmente que as sondagens efectuadas por Cruz e Silva foram tapadas e «0 terreno continuou a dar trigo» e que «Não chegámos a concluir o trabalho por ser necessário tapar tudo de modo a não impedir a cultura do trigo» (ALMEIDA, 1963: 149).
} 
uma pequena nota referente à descoberta de uma sepultura com vidros e um anel, em 1841 (BIERS, et alii, 1988: 5) poderão ser indícios das mesmas. Não há, contudo, quaisquer outros dados que nos esclareçam sobre a sua tipologia e cronologia.

Em 1995, na encosta onde se têm desenvolvido escavações na área limítrofe à capela de S. Brás, apareceram duas sepulturas de forma sub-rectangular escavadas no xisto, com as paredes do topo formadas por lajes postas genericamente na vertical, sobressaindo-se as que delimitavam a zona da cabeceira e que se salientavam do nível do terreno. As duas sepulturas estão orientadas no sentido W/E.

Nenhuma delas continha espólio, tendo apenas o esqueleto da Sep. 1 junto aos dedos da mão direita um aro em bronze, que deveria tratar-se de um anel. O seu estado de conservação não permite, no entanto, a atribuição de uma cronologia.

Com uma arquitectura semelhante há paralelos de sepulturas romanas no Nordeste Alentejano, como as de Serrones, Elvas; Padrãozinho, Vila Viçosa; Pombais, Marvão (FRADE, 1993: 853 e 858), se bem que a orientação das sepulturas de Miróbriga (o crânio virado a Poente) e a ausência de espólio indiquem que se devem tratar de exemplares muito tardios. A sua localização, junto a uma casa que se encontra em fase de escavação, que deve ter estado em uso até ao século IV, como parece apontar a cronologia de alguns dos materiais arqueológicos aí exumados, reforça a ideia de se tratarem de sepulturas pertencentes ao declínio do aglomerado urbano ou mesmo posteriores ${ }^{88}$.

A existência dessas sepulturas tardias ${ }^{89}$, já provavelmente medievas, que devem pertencer a uma necrópole mais vasta, não nos dão, assim, nesta fase dos conhecimentos, qualquer pista quanto à organização espacial do oppidum romanizado e dos acessos ao mesmo.

Haveria, pois, que conhecer as necrópoles correspondentes à ocupação efectiva do aglomerado, para daí se poderem tirar quaisquer conclusões quanto a algumas das características do mesmo e da rede viária que o uniria a outras localidades.

Ainda durante o corrente Inverno, foi identificada, devido às fortes chuvadas que assolaram a região, uma terceira sepultura que ainda não foi escavada, que aponta

\footnotetext{
${ }^{88}$ Segundo José Carlos Oliveira, director do Museu Regional de Beja, que estudará mais detalhadamente estes dois esqueletos, nas sepulturas deve ter havido a intrusão de animais, uma vez que partes dos esqueletos nāo estavam em conexão anatómica.

${ }^{89}$ Em Pollentia foi escavada uma necrópole tardo-romana, onde algumas sepulturas feitas com lajes laterais e cobertura podem ser um bom paralelo para Miróbriga. Algumas das sepulturas apresentam uma laje na cabeceira, colocada na vertical, ao modo de estela, sem qualquer espólio. Muitos dos esqueletos encontravamse numa posição semelhante aos de Miróbriga, com os braços ao longo do corpo e cabeça virada para o Oeste. Estas sepulturas foram datadas do séulo IV d. C. (ARRIBAS e TARRADELL, 1987: 136).
} 
para o período tardo-romano, pois são visíveis à superfície as telhas laterais de grandes dimensões que deveriam delimitar a caixa.

\section{Conclusão}

Como expressámos ao longo deste trabalho onde, de algum modo, levantámos algumas das questões que, do nosso ponto de vista, dificultam a abordagem deste Sítio Arqueológico, no estado actual dos conhecimentos, e ainda as que se prendem com o processo de romanização no Sudoeste Peninsular, e mais especificamente da ciuitas de Miróbriga -, mais do que conclusões, poderemos apontar caminhos para uma futura investigação.

Gostaríamos, no entanto de apresentar, as duas vertentes de trabalho que nos propomos delinear: o Aglomerado Urbano e a sua Ciuitas.

No que se refere ao aglomerado urbano e às construções que nele se inserem, somos confrontadas com a dificuldade em poder atribuir uma cronologia segura a grande parte das estruturas arquitectónicas conhecidas, uma vez que os materiais arqueológicos inéditos, em depósito em Miróbriga ou no Museu Municipal de Santiago do Cacém, provenientes de antigas escavações, não possuem qualquer contexto arqueológico ou alguma referência relativa ao seu achado.

Muitas das publicações de materiais arqueológicos de Miróbriga, se bem que nos sejam úteis do ponto de vista das balizas de ocupação do aglomerado, participam, contudo, dessa dificuldade em contextualizar os achados, porque da maioria dos espécimes descritos e classificados se desconhece o local de origem. Acresce-se ainda a estas dificuldades o facto das sondagens efectuadas pela equipa luso-americana no forum e nas áreas residenciais, cujo conhecimento seria do maior interesse para o nosso trabalho, não terem sido, infelizmente, publicadas.

Torna-se, também, fundamental clarificar algumas das zonas parcialmente escavadas em anteriores trabalhos arqueológicos, como as termas, cujos edifícios, embora conhecidos em grande parte, não o são na totalidade; as construções que se desenvolvem no lado sul do forum, identificadas como tabernae; as edificações que se situam junto à calçada que desce em direcção às termas e as zonas habitacionais, entre outras.

Estas acções permitirão, de algum modo, ajudar a compreender as estruturas básicas do aglomerado romano. Por outro lado, é fundamental promover um estudo aprofundado dos vestígios da ocupação sidérica em Miróbriga, efectuando sondagens e escavações em alguns pontos.

Paralelamente deverão ser feitos registos pormenorizados dos vestígios dispersos 
na envolvente da zona nuclear do aglomerado urbano, que permitam uma melhor definição da extensão de Miróbriga.

A segunda vertente de investigação - a ciuitas - prende-se com a necessidade de entender a forma como se processou a ocupação deste território. Do nosso ponto de vista, deverá ser efectuado um levantamento exaustivo dos povoados da Idade do Ferro que foram romanizados nesta região. Estes dados deverão ser confrontados com as cronologias apontadas para os vestígios de ocupação romana ex-novo, de molde a poder aferir-se a existência (ou não) de um possível modelo de romanização no Sudoeste Peninsular e as cronologias respeitantes a uma ocupação plena do território.

É também imprescindível fazer um levantamento sistemático dos recursos agropecuários, piscícolas e mineiros que justificam a implantação romana, e tentar identificar os mecanismos de produção e de circulação de bens e mercadorias, pois só assim é possível uma melhor caracterização da ciuitas de Miróbriga.

\section{BIBLIOGRAFIA}

ABASCAL PALAZÓN, Juan Manuel, 1997, «Las Termas Monumentales de Segobriga», Revista de Arqueología, Ano XVIII, nº 195, Zugarto Ediciones, Madrid, pp. 38-45.

ABASCAL PALAZÓN, Juan Manuel e ESPINOSA, Urbano, 1989, La Ciudad Hispano-Romana: privilegio y poder, Colegio Oficial de Aparejadores y Arquitectos Tecnicos, Logroño.

ADAM, Jean-Pierre, 1989, La Construction Romaine, Éditions Picard, Paris.

ALARCÃO, Jorge de, 1976, «A Vida Rural no Alentejo na Época Romana», Conimbriga, XV, Coimbra, pp. 5-44.

ALARCÃO, Jorge de, $1985^{1}$, Introdução ao Estudo da Casa Romana, Coimbra.

IDEM, 1985², «Sobre a Romanização do Alentejo e Algarve. A Propósito de uma Obra de José d'Encarnação», Arqueologia, 11, Junho, pp. 99-111.

IDEM, 1988, O Domínio Romano em Portugal, Publicações Europa-América, Lisboa. IDEM,1988, Roman Portugal, Aris \& Phillips Ltd, Warminster.

IDEM, 1989, «Recensões Bibliográficas», Conimbriga, Vol. 28, Universidade de Coimbra, pp. 243-245.

IDEM, 1990 «O Domínio Romano», Nova História de Portugal, Editorial Presença, Lisboa. 
IDEM, 1990², «A Urbanização de Portugal nas Épocas de César e de Augusto», Actas do Colóquio "Stadtbild und Ideologie» (Outubro de 1987), Bayerischen Akademie der Wissenschaften, Munique, pp. 43-58.

IDEM, 1992, «A Cidade Romana em Portugal: A Formação de Lugares Centrais em Portugal, da Idade do Ferro à Romanização», As Cidades e a História, Fundação Calouste Gulbenkian, Lisboa, pp. 35-70.

IDEM, 1992, «A Cidade Romana em Portugal - Renovação Urbana em Portugal na Época Romana», As Cidades e a História, Fundação Calouste Gulbenkian, Lisboa, pp. 73-127.

IDEM, 1993, «Les Ciutats Romanes de Portugal», La Ciutat Hispano-Romana, Ministerio de Cultura, Àmbit Serveis Editorials, S.A., Barcelona.

ALARCÃO, J. de e ETIENNE, Robert, 1974 a 1978, Fouilles de Conimbriga, E. de Boccard, Paris.

ALARCÃO et alii, 1994, «Dezasseis anos de Arqueologia em Braga: problemática da Reconstituição de uma Cidade Romana», Actas do Encontro de Arqueologia Urbana, Bracara Augusta, No 97, Vol. XLV, Câmara Municipal de Braga, pp. 71-81.

ALBERTOS, M. L., 1990, "Los Topónimos en -briga en Hispania", Veleia 7, pp. 131-146.

ALFÖLDY, Géza, 1994: «Evergetismo en las ciudades del Imperio Romano», Actas do XIV Congreso Internacional de Arqueologia Clásica, I, Tarragona., pp. 63-67.

ALMEIDA, D. Fernando de, 1963, «Nota sobre os Restos do Circo Romano de Miróbriga dos Célticos», Revista de Guimarães, $\mathrm{n}^{\circ} \mathrm{s}$ 1-2.

ALMEIDA, D. Fernando de, 1964, Ruínas de Miróbriga dos Célticos (Santiago do Cacém), Junta Distrital de Setúbal.

IDEM, inédito 1972, Miróbriga dos Célticos, Delimitação da Área Arqueológica e Incremento das Escavações, "Arquivo Morto" do Museu Nacional de Arqueologia, Lisboa.

IDEM, 1988, «Breve Notícia sobre o Santuário Campestre Romano de Miróbriga dos Célticos», Gerion, Anexo I, Faculdade de Geografia e Historia da Universidade Complutense de Madrid.

AMARAL, João Ferreira do e Augusto Ferreira do, 1997, Povos Antigos em Portugal, Quetzal Editores, Lisboa.

AQUILUÉ, Xavier et alii, 1991, Tarraco - Guía Arqueológica, Edicions El Mèdol, Tarragona. 
ARANEGUI GASCÓ, Carmen et alii, 1987, «El Foro de Saguntum: La Planta Arquitectónica», Los Foros Romanos de las Provincias Occidentales, Ministério de Cultura, Madrid, pp. 73-97.

ARANEGUI GASCÓ, Carmen, 1992, «Un Templo Republicano en el Centro Cívico Saguntino», Templos Romanos de Hispania, Cuadernos de Arquitectura Romana, Universidad de Murcia, pp .67-82..

IDEM, 1994, «De la ciudad Ibérica a la Ciudad Romana: Sagunto», Actas do XIV Congreso Internacional de Arqueología Clásica, I, Tarragona., pp. 69-78.

ARBULO BAYONA, Joaquín Ruiz de, 1992, «El Templo del Foro de Ampurias y la Evolución de los Foros Republicanos», Templos Romanos de Hispania, Cuadernos de Arquitectura Romana, Universidad de Murcia, pp. 11-37.

ARRIBAS; Antonio e TARRADELL, 1987: «El Foro de Pollentia. Noticias de las Primeras Investigaciones", Los Foros Romanos de las Provincias Occidentales, Ministério de Cultura, Madrid, pp.121-136.

ARTHUR, Maria de Lourdes Costa, 1983, «Meróbriga. Santiago do Cacém», Caesaraugusta 57-58, Institución Fernando el Católico, Zaragoza.

BALIL, A, 1987, «Forum y Fora en el Noroeste Peninsular», Los Foros Romanos de las Provincias Occidentales, Ministerio de Cultura, Madrid.

BALTY, Jean CH. 1991, CVRIA ORDINIS, Palais des Académies, Bruxelas.

IDEM., 1994, «Le Centre Civique des Villes Romaines et ses Espaces Politiques et Administratifs», Actas do XIV Congreso Internacional de Arqueología Clásica, I, Tarragona, pp. 91-107.

BARATA, Maria Filomena Santos, 1990, «Conservação, Salvaguarda e Valorização dos Sítios Arqueológicos - Uma Reflexão», Actas das IV Jornadas Arqueológicas, Associação dos Arqueólogos Portugueses, Lisboa, pp.61-67.

IDEM, 1993, «Alguns Vidros Romanos do Museu de Santiago do Cacém», Vipasca $\mathrm{n}^{\mathrm{o}} 2$, pp.73-76.

IDEM, 1993, «A Cidade Romana de Miróbriga, Portugal», Revista de Arqueología, Maio 1993, Zugarto Ediciones, Madrid, pp.36-47.

IDEM, 1993, «A Cidade Romana de Miróbriga», Al-Madan, Julho1993, Almada, pp 13-20.

IDEM, 1993, Resenha Historico-Urbanística de Santiago do Cacém, Gabinete Técnico Local da Câmara Municipal de Santiago do Cacém (Inédito, Arquivo IPPAR). 
IDEM, 1994, «A propósito do Touro esculpido de Miróbriga», Vipasca, n³, Aljustrel, pp. 73-77.

IDEM, 1994, «Conservação, Salvaguarda e Valorização dos Sítios Arqueológicos em Meio Urbano", Actas do Encontro de Arqueologia Urbana, Braga, pp. 265-276. IDEM, 1994, "O Território de Miróbriga», Actas do XIV Congreso Internacional de Arqueología Clásica, II, Tarragona, pp. 128-132.

IDEM, 1997, «Ruínas de Miróbriga”, Pelo Caminho das Pedras, Câmara Municipal de Santiago do Cacém, pp.19-21.

BARATA, Maria Filomena Santos e CORREIA, Susana Helena, 1992, Miróbriga no Mundo Romano, C. M. Santiago do Cacém.

BARATA, Filipe Themudo e MASCARENHAS, José Manuel de, 1997, «Território de Ebora, e a Organização e Ordenamento da Paisagem Envolvente», Paisagens Arqueológicas a Oeste de Évora, Câmara Municipal de Évora, pp. 61-70.

BARRERA ANTON, José Luis de la, 1984, Los Capiteles Romanos de Mérida, Monografias Emeritenses, 2, Museo Nacional de Arte Romano,

BARRIENTOS VERA, 1997, «Baños romanos em Mérida», Mérida, Excavaciones Arqueológicas, Consorcio Ciudad Monumental Histórico-artística y Arqueológica de Mérida, pp. 259-279.

BARROSO, Yolanda e MORGADO, Francisco, 1997, Mérida, Consorcio de la Ciudad Monumental Histórico-Artística y Arqueológica de Mérida.

BATATA, Carlos, 1997, Carta Arqueológica do Concelho de Tomar, Centro de Estudos e Protecção do Património da Região de Tomar, Tomar.

BAYET, Jean, 1994, La Religion Romana Historia política y psicológica, Ediciones Cristiandad, Madrid

BEDON, Robert et alii, 1988, Architecture et Urbanisme en Gaule Romaine, Editions Errance, Paris.

BENDALA GALÁN, Manuel et alii, 1987, «Aproximación al urbanismo prerromano y a los fenómenos de transición y de potenciación tras la Conquista», Los Asentamientos Ibéricos ante la Romanización, Ministerio de Cultura, Madrid, pp. 121-140.

IDEM, 1989-90, «Capitolia Hispaniarum», Anas, 2-3, Mérida, pp. 11-36.

IDEM, 1990, «El Plan Urbanístico de Augusto en Hispania: Precedentes y Pautas Macroterritoriales», Actas do Colóquio «Stadtbild und Ideologie» (Outubro de 1987), Bayerischen Akademie der Wissenschaften, Munique, pp. 25-42. 
IDEM, 1992, «Materiales de Construcción Romanos: peculiaridades de Hispania», Ciencias, Metodologias y Técnicas Aplicadas a la Arqueología, Ed. Isabel Rodá. Fundación Caixa de Pensions. Publicacions de la Universitat Autònoma de Barcelona, Barcelona.

IDEM, 1993: (Dir.), La Ciutat Hispano-Romana, Ministerio de Cultura, Tarragona.

IDEM, 1994, «La Ciudad en la Hispania Romana», Actas do XIV Congreso Internacional de Arqueología Clásica, La Ciudad en el Mundo Romano, I, Tarragona, pp. 115-123.

BENDALA GALÁN, Manuel e ROLDÁN GÓMEZ, Lourdes, 1993, Técnicas Constructivas Romanas en Italica, Universidad Autonoma de Madrid, Madrid.

BÉRENGER, 1993, «Le Mondes des Cités», Sources d'Histoire Romaine, Larousse, Paris, pp. 273-290.

BERROCAL RANGEL, Luis, 1987, «La Urbanística de Augusta Emerita», I e II, Revista de Arqueología, ${ }^{\circ}$ s 71 e 72, Zugarto Ediciones, Madrid, pp. 36-45 e 29-39.

IDEM, 1989-1990, «Cambio Cultural y Romanización en el Suroeste Peninsular», Anas 2-3, pp. 103-122, Museo Nacional de Arte Romano, Mérida.

IDEM, 1992, Los Pueblos Célticos del Suroeste de la Peninsula Iberica, Editorial Complutense, Madrid.

IDEM, 1995, «La Beturia: Definición y caracterización de un territorio prerromano», Celtas y Turdulos: La Beturia, Museo Nacional de Arte Romano, Mérida, pp. 153-180.

BIERS, William et alii, 1981' ${ }^{1}$, Investigações em Miróbriga, Caixa de Crédito Agrícola Mútuo de Santiago do Cacém.

BIERS, William et alii, 19812, «Investigations at Mirobriga, Portugal in 1981», Muse 15, Missouri-Columbia.

BIERS, Jane e William, SOREN, David, 1982, «Excavations at Mirobriga: The 1982 Season», Muse, 16, Missouri-Columbia.

BIERS, Jane e William, SLANE, Kathleen W., SOREN, David, 1983, «Mirobriga: The 1983 Season», Muse, 17, Missouri-Columbia.

BIERS, Jane, DARLING, Janina, MIKSICEK, Charles, SLANE, Kathleen e SOREN, David, 1984, Mirobriga: A Portuguese-American Project in Southern Portugal, Muse, 18, Missouri-Columbia.

BIERS, William, 1985, «Classical Forms and Ideas at Mirobriga, Portugal», IIPAKTIKA, AOHNA, pp. 37- 41 
BIERS, William et alii, 1988, Mirobriga, BAR International Series 451, Oxford BLANCO, A., 1982, «Arte de la Hispania Romana. Arquitectura, escultura, pintura, mosaicos, artes menores», Historia de España. España Romana (218 a.C.-414 d.C.).II. La sociedad, el derecho, la cultura, Madrid, pp. 557 e ss.

BLÁZQUEZ, José María, 1991, Urbanismo y Sociedad en Hispania, Ediciones Istmo, Madrid.

IDEM, 1991, «Arquitectura Romana e Siria», Revista de Arqueología, n 125, Zugarto Ediciones, Madrid, pp. 40-50.

IDEM, 1991, «El Urbanismo en Siria», Revista de Arqueología, n 126, Zugarto Ediciones, Madrid, pp.44-56.

BLÁZQUEZ, José María; MONTERO, Santiago e MARTÍNEZ-PINNA, Jorge, 1993, Historia de las Religiones Antiguas: Oriente, Grecia y Roma, ediciones Cátedra, Madrid.

BLUTSTEIN-LATRÉMOLIÉRE, E., 1991, «Les Places Capitolines d'Espagne». Mélandes de la Casa de Velazques, XXVII, 1, pp 43-64, Paris.

BURGHOLZER, Gunther, 1993, «Das Sacellum vom Cerro de Maquiz», Madrider Mitteilungen, 34, Mainz.

IDEM, 1994, «Templos in antis de la Península Ibérica», Actas do XIV Congreso Internacional de Arqueología Clásica, II, Tarragona, pp. 78-79.

CABRAL, Caldeira, Francisco, 1960, A Árvore, Ministério das Obras Públicas, Lisboa.

CABRAL, Maria Elisabeth Figueiredo Neves, 1976-77, «Lucernas romanas de Miróbriga», Setúbal Arqueológica», II-III, pp. 455-468.

CANTO, Alicia $\mathrm{M}^{\mathrm{a}}, 1989$, «Colonia Iulia Augusta Emerita: consideraciones en torno a su fundación y territorio», Gerión, 7, p. 149 e ss.

IDEM, 1990, «Las tres fundaciones de Augusta Emerita», Actas do Colóquio Stadtbild und Ideologie (Outubro de 1987), Bayerischen Akademie der Wissenschaften, Munique, pp. 289-298.

CARRERA RAMÍREZ, Fernando, 1993, «La Conservación de Yacimientos Arqueológicos Excavados», Arqueología y Conservación, Xinzo de Limia, pp. 101-113.

CENTENO, Rui, 1983, «A Dominação Romana», História de Portugal, Publicações Alfa, Lisboa, pp.148-211.

CENTENO, Rui M. S. e SILVA, Armando Coelho Ferreira, 1996, «A Citânia de Sanfins», De Ulisses a Viriato, Museu Nacional de Arqueologia, Lisboa, pp. 134-135. 
IDEM, 1996, «A Citânia de Briteiros» De Ulisses a Viriato, Museu Nacional de Arqueologia, Lisboa, pp. 136-138.

CERRILLO MARTÍN DE CÁCERES, Enrique, 1995, «Los Últimos Romanos en Lusitania. Entre la Tradición y el Cambio». Los Ultimos Romanos en Lusitania, Museo Nacional de Arte Romano, Mérida, pp. 13-48.

CORREIA, Susana Helena,1987, «Estação Arqueológica de Miróbriga (Santiago do Cacém), Balanço de uma Investigação e Perspectivas de Intervenções Futuras», Anais da Real Sociedade Arqueológica Lusitana, Santiago do Cacém, pp. 47-50.

CORREIA, Susana Helena, 1990, Miróbriga, Roteiros da Arqueologia Portuguesa, Instituto Português do Património Cultural, Lisboa.

CORREIA, Susana Helena e OLIVEIRA, José Carlos, 1992, "Intervenções Arqueológicas do Serviço Regional de Arqueologia da Zona Sul no Baixo Alentejo", Trabalhos de Antropologia e Etnologia, Vol. 32, Porto, pp. 315-321.

CORREIA, Virgílio Hipólito, 1995 "A Transição entre o Período Orientalizante e a Idade do Ferro na Betúria Ocidental (Portugal)», Celtas e Turdulos: la Beturia, Museo Nacional de Arte Romano, Merida, pp. 129-149.

IDEM, 19952, "The Iron Age in South and Central Portugal and the Emergence of Urban Centres», Social Complexity and the Development of Towns in Iberia (From the Copper Age to the Second Century AC), ed. Barry Cunliffe \& Simon Keay, Oxford University Press, pp. 237-262.

IDEM, 1996: «Os Povoados da $1^{\text {a }}$ Idade do Ferro do Sul de Portugal», De Ulisses a Viriato, Museu Nacional de Arqueologia, Lisboa, pp. 82-93.

DIAS, Luisa Ferrer, 1976-77, «Terra Sigillata de Miróbriga», Setúbal Arqueológica, II-III, pp. 361-422.

DIAS, Lino Tavares, 1996, «Contributo para a Análise do Ordenamento do Território marginal do Rio Douro», Douro - Estudos \& Documentos. Ano n², pp. 31-55.

DIAS, Lino Tavares, 1997, Tongobriga, IPPAR, Lisboa.

DUPRÉ I RAVENTÓS, Xavier, 1990, «Un Gran Complejo Provincial de Época Flavia en Tarragona: aspectos cronológicos», Actas do Colóquio "Stadtbild und Ideologie» (Outubro de 1987), Bayerischen Akademie der Wissenschaften, Munique, pp. 319-327.

IDEM, 1995, "New Evidence for the Study of the Urbanism of Tarraco», Social Complexity and the Development of Towns in Iberia (From the Copper Age to the Second Century $A C$ ), ed. Barry Cunliffe \& Simon Keay, Oxford University Press, pp. 355-369. 
DURÁN CABELLO, Rosalia María, 1991-92, «Técnicas de Edilicia Romana en Mérida (I)»; Anas, IV-V, Mérida, pp. 45-80.

ENCARNAÇÃO, José, 1975, Divindades Indígenas sob o Domínio Romano em Portugal, Lisboa.

IDEM, 1984, Inscrições Romanas do Conventus Pacensis, Instituto de Arqueologia, Faculdade de Letras de Coimbra.

IDEM, 1987, «Monumento Funerário posto a descoberto em Santa Margarida do Sado (Ferreira do Alentejo)», Anais da Real Sociedade Arqueológica Lusitana, Santiago do Cacém, pp. 31-36.

IDEM, 1993: «Decreto decurionum. Algumas notas sobre o mecanismo decisório municipal na Hispânia romana», Ciudad y Comunidad Cívica en Hispania (Siglos II y III d. C.), Casa de Velázquez, Madrid, pp. 59-64.

IDEM, 1990, «A Religião», Nova História de Portugal, Editorial Presença, Lisboa.

IDEM, 1991, «Recensões Bibliográficas», Conimbriga, 30, Faculdade de Letras de Coimbra.

IDEM, 1996, "Problemas em aberto na Epigrafia Mirobrigense", Conímbriga, $\mathrm{n}^{\circ} 35$, Faculdade de Letras de Coimbra, pp.129-146.

ENRÍQUEZ NAVASCUÉS, Juan Javier, 1995, «Los Pueblos Prerromanos de Extremadura», Celtas y Turdulos: la Beturia, Museu Nacional de Arte Romano, Mérida, pp. 49-76.

IDEM, 1997, «La Mérida Prerromana y el Poblamiento Pre y Protohistórico de su Comarca», Mérida, Ciudad y Patrimonio, nº 1 , Consorcio Ciudad Monumental Histórico-artística y Arqueológica de Mérida, pp. 29-43.

ÉTIENNE, Robert, 1974, Le Culte Impérial dans la Péninsule Ibérique d'Auguste à Diocletien, Paris.

ÉTIENNE, Robert, 1993: «Sociabilité et Hiérarchie urbaine dans la Péninsule Ibérique romaine impériale», Ciudad y Comunidad Cívica en Hispania (Siglos II y III d. C.), Casa de Velázquez, Madrid, pp. 85-91.

EUZENNAT, Maurice, 1994, «Principia militares e forums civils», Actas do XIV Congreso Internacional de Arqueología Clásica, I, Tarragona, pp.197-203.

FABIÃO, Carlos, 1992, «O Passado proto-histórico e Romano», História de Portugal, ed. Círculo de Leitores, Lisboa.

IDEM, 1993-1994, «O Azeite da Bética na Lusitania», Conimbriga, 32-33, pp. 219- 
245, Faculdade de Letras de Coimbra.

FALCÃO, Bernardo, pub.em 1931-32, «Memórias da Antiga Miróbriga» (segundo manuscrito do século XVIII), Nossa Terra, $\mathrm{n}^{\circ}$ s 10, 12, 14, 17, 18, 20, 21, 23, 28.

FALCÃO, José António et alii, 1988, «Epigrafia Romana do Concelho de Santiago do Cacém», Anais da Real Sociedade Arqueológica Lusitana, $2^{\mathbf{a}}$ série, Santiago do Cacém, pp. 37 a 49.

FARIA, António Marques, 1995, «Plínio-o-Velho e os Estatutos das Cidades Privilegiadas Hispano-Romanas Localizadas no Actual Território Português», Vispasca, ${ }^{\circ}$ 4, Aljustrel, pp. 89-99.

FASOLO, Furio, 1962, «L'Architettura Romana di Efeso», Bollettino del Centro di Studi per la Storia dell' Architettura, 18, Casa dei Crescenzi, Roma.

FAUDUET, Isabelle, 1993, Atlas des Sanctuaires Romano-Celtiques de Gaule, «Archeologie Aujourd'hui», Editions Errance, Paris.

IDEM, 1993, Les Temples de Tradition Celtique en Gaule Romaine, Editions Errance, Paris.

FEIO, Mariano, 1983, Le Bas Alentejo et l'Algarve, Instituto Nacional de Investigação Científica, Évora.

FERNÁNDEZ VEGA, Pedro Ángel, 1993, Arquitectura y Urbanística en la Ciudad Romana de Julióbriga, Universidad de Cantabria, Ayuntamiento de Torrelavega.

FERREIRA, Carlos Jorge Alves et alii, 1993, O Património Arqueológico do Distrito de Setúbal, Associação de Municípios do Distrito de Setúbal, Setúbal.

FINCKER, Myrriam e TASSAUX, Francis, 1992, «Les Grands Sanctuaires "Ruraux" d'Aquitaine et le Culte Impérial», Mélanges de l'École Française de Rome - Antiquité, Tomo 104-1, Roma.

FONSECA, Rita, 1993, «Evolução Morfológica do Sistema Lagunar de Santo André ao longo de 40 anos», Actas do Encontro sobre a Lagoa de Santo André, Associação Cultural de Santiago do Cacém, pp. 11-28.

FORTES, Mário, 1997, Ruínas Romanas de Miróbriga: Qualidade Visual da Paisagem - Programa Preliminar. IPPAR, Lisboa

FRADE, Helena, 1994, «La Tecnique Constructive de Quelques Monuments de la Lusitanie», L'Africa Romana, Cartagena, pp. 1017-1027.

FRADE, Helena e CAETANO, José Carlos, 1993, «Ritos Funerários Romanos no Nordeste Alentejano», Actas do II Congresso de História Antiga, Coimbra, pp. 847-872. 
GARCÌA Y BELLIDO, 1966, Urbanistica de las Grandes Ciudades del Mundo Antiguo, Instituto Español de Arqueologia, Madrid.

GOMES, Mário Varela e SILVA, Armando Coelho Ferreira da, 1994, Proto-História de Portugal, Universidade Aberta, Lisboa.

CONGÉS, Anne Roth, 1987, «L'hypothèse d'une basilique à deux nefs à Conimbriga et les transformations du forum», Mélanges de l'École Française de Rome. Antiquité, 99, pp. 711-751.

GRANT, Michael, 1970, The Roman Forum, Weidenfeld \& Nicolson, Londres

GROS, Pierre, 1990, «Téatre et culte impérial en Gaule Narbonnaise et dans la Péninsule Ibérique», Actas do Colóquio «Stadtbild und Ideologie» (Outubro de 1987), Bayerischen Akademie der Wissenschaften, Munique, pp. 381-390.

IDEM, 1993, «Comprendre la Ville Romaine? Perspectives et Problémes d'une Approche Structurelle», Actas do XIV Congreso Internacional de Arqueología Clásica, I, Tarragona, pp. 45-55.

IDEM, 1994, «L'Amphithéâtre dans la Ville Politique "Culturelle"et Urbanisme aux Deux Premiers Siècles de l'Empire», El Anfiteatro en la Hispania Romana, Junta de Extremadura, Mérida, pp. 13-29.

IDEM, 1996, L'Architecture Romaine, Picard Editeur, Paris.

GROS, Pierre e TORELLI, Mario, ed. 1992, Storia dell' Urbanistica, Il Mondo Romano, Editori Laterza, Roma-Bari.

GRÜNHAGEN, Wilhelm, 1970, «Escavações nos Terraços do Santuário de Munigua», Actas e Memórias do I Congresso Nacional de Arqueologia, Instituto de Alta Cultura, Lisboa, pp. 95-103.

GUITART I DURAN, Josep, 1993, «La Ciutat Romana en 'àmbit de Catalunya», in La Ciutat Hispano Romana, Ministério da Cultura, Tarragona

GUICHARD, Pascal, 1993: «Les effets des mesures flaviennes sur la hiérarchie existant entre cités de la Péninsule Ibérique», Ciudad y Comunidad Cívica en Hispania (Siglos II y III d. C.) , Casa de Velázquez, Madrid, pp. 67-84.

HAUSCHILD, Theodor, 1989-90, «Arquitectura Religiosa Romana em Portugal», Anas, n's 2-3, Museo Nacional de Arte Romano, Mérida, pp. 57-76.

IDEM, 1992, «Los Templos Romanos de Munigua (Sevilla)», Templos Romanos de Hispania, Cuadernos de Arquitectura Romana, Universidad de Murcia, pp. 133-143. IDEM, 1992, «El Templo Romano de Évora», Templos Romanos de Hispania, Cua- 
dernos de Arquitectura Romana, Universidad de Murcia, pp. 107-117.

IDEM, 1994, «El Templo Romano de Évora, Nuevas Investigaciones», Actas do XIV Congreso Internacional de Arqueología Clásica, II, Tarragona, pp. 197-200.

IDEM, 1997, «Milreu, Estói (Faro) Villa romana e Santuário», Noventa Séculos entre a Serra e o Mar, IPPAR, Lisboa, pp. 407-413.

HORNE, P. e KING. A., 1981, «Roman Celtic Temples in Continental Europe: a Gazetter of those with known Plans», Temples, Churches and Religion, BAR, British Series, 109, p. 21.

JIMÉNEZ SALVADOR, José Luis, $1987^{1}$, Arquitectura Forense en la Hispania Romana, Departamento de Ciencias de la Antigüedad, Universidad de Zaragoza, Zaragoza.

IDEM, 1987², «Los Modelos Constructivos en la Arquitectura Forense de la Península Ibérica», Los Foros Romanos de las Provincias Occidentales, Ministerio de Cultura, Madrid, pp. 173-177.

IDEM, 1989-90, «Arquitectura Religiosa Romana en Corduba Colonia Patricia: Panorama y Perspectivas», Anas 2-3-, Museu Nacional de Arte Romano, Mérida, pp. 77-86.

JÚDICE GAMITO, Teresa, 1986, Social Complexity in Souhwest Iberia (8th to 3rd cents.B.C.) - Aspects of evolution and interaction, Cambridge.

KEAY, S.J., 1988, Roman Spain, British Museum Publications Limited, Londres.

IDEM, 1994, «Towns in the Roman World: Economic Centres or Cultural Symbols?», Actas do XIV Congreso Internacional de Arqueología Clásica, I, Tarragona pp. 253-259.

IDEM, 1995, «Innovation and Adaptation: The Contribution of Rome to Urbanism in Iberia», Social Complexity and the Development of Towns in Iberia (From the Copper Age to the Second Century AC), ed. Barry Cunliffe \& Simon Keay, Oxford University Press, pp. 291-337.

KURTZ, 1995, William S. «Lo Céltico en el Contexto de la Arqueología Europea», Celtas y Turdulos: La Beturia, Museo Nacional de Arte Romano, Mérida, pp. 9-48.

LEAL, Pinho, 1880, Diccionario Geographico, Vol. 9, Livraria Editora de Mattos Moreira \& Companhia.

LE ROUX, Patrick, 1995, Romains d'Espagne, Cités et Politique dans les Provinces $I^{e}$ siècle av.J.-C. III siècle ap. J.-C., Armand Colin Éditeur, Paris.

LE ROUX, Patrick e TRANOY, 1983/84, «Villes et Fonctions Urbaines dans le NordOuest Hispanique sous Domination Romaine», Portugalia, Instituto de Arqueologia 
da Faculdade de Letras do Porto, pp. 199-207.

LE ROUX, Patrick, 1993, «Peut-on parler de la cité hispano-romaine aux $\mathrm{II}^{\mathrm{e}}-\mathrm{III}^{\mathrm{e}}$ siècles?», Ciudad y Comunidad Cívica en Hispania (Siglos II y III d. C.) , Casa de Velázquez, Madrid, pp.188-195.

IDEM, 1995, Romains d'Espagne, Cités et Politique dans les Provinces II siècle av.J.-C. III siècle ap. J.-C., Armand Colin Éditeur, Paris.

LEÓN ALONSO, Pilar, 1977-78, «Notas sobre Técnica Edilicia en Itálica», AEspA 50-51, pp. 143 e ss.

IDEM, «Arqueologia de Italica», Revista de Arqueología, ano 4, n 30, Zugarto Ediciones Madrid, pp. 38-50.

IDEM, 1990, «Ornamentación Escultórica y Monumentalización en las Ciudades de la Bética», Actas do Colóquio «Stadtbild und Ideologie», (Outubro de 1987), Bayerischen Akademie der Wissenschaften, Munique, pp. 367-380.

IDEM, 1993, «La Ciutat Hispano-Romana a Andalusia», La Ciutat Hispano-Romana, Barcelona, pp. 12-53.

IDEM, 1995, Esculturas de Itálica, Junta de Andalucia. Consejería de Cultura.

LOBATO, «A Necrópole Romana de Gulpilhares», Vila Nova de Gaia, Portugalia, Nova Série, Vol. XVI, pp. 31-110.

LUZÓN NOGUÉ, José Ma, 1982, «Consideraciones sobre la Urbanistica de la Ciudad Nueva de Italica», ITALICA, Actas da las Primeras Jornadas sobre Excavaciones Arqueológicas en Itálica, Ministerio de Cultura, Sevilha, pp. 77-95.

Pe. MACEDO E SILVA, António, 1869, Annaes do Municipio de Sant'Iago de Cacem, Vol.I e II, Imprensa Nacional, Lisboa.

MAIA, Manuel, 1980, «Povos do Sul de Portugal nas Fontes Clássicas», Clio 2, pp. 67-70.

IDEM, 1988, «Os Castella do Sul de Portugal», Actas do I Encontro de Arqueologia

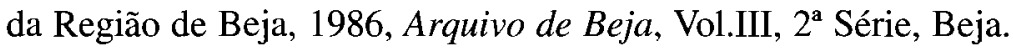

MAIA, Manuel e Maria Garcia, 1996, «Os Castella do Sul de Portugal e a Mineração da Prata nos Primórdios do Império», Mineração no Baixo Alentejo, Câmara Municipal de Castro Verde, pp. 60-81.

MAÑANES, Tomás, 1983/84, «Asturica Augusta, la Ciudad y su Entorno», Portugalia, Instituto de Arqueologia da Faculdade de Letras do Porto, pp. 215-229. 
MAÑANES, T. e SOLANA, J.M., 1978, «Ciudades y Vias Romanas en la Cuenca del Duero», Hispania Antigua, VII, Valladolid.

MANSUELLI, G.A., 1974, «Considerazzioni sull'urbanistica della Spagna romana». Colóquio italo-espanhol Hispania Romana, Roma, pp. 87-94.

MANTAS, Vasco Gil, 1987, «As Primitivas Formas de Povoamento Urbano em Portugal», Povos e Culturas, Centro de Estudos dos Povos e Culturas de Expressão Portuguesa, Universidade Católica, Lisboa, pp. 13-55.

MANTAS, Vasco Gil, 1988, «Implantação Rural Romana em torno da Villa de S. Cucufate», Arquivo de Beja, III volume, $2^{a}$ série. pp:199-214. », Noventa Séculos entre a Serra e o Mar, IPPAR, Lisboa.

IDEM, 1990, "Teledeteç̧ão e Urbanismo Romano: O Caso de Beja", Geociências, Revista da Universidade de Aveiro, Vol. 5, fasc. 1 (75-88).

IDEM, 1993, «As Fundações Coloniais no Território Português nos Finais da República e Inícios do Império», Actas do II Congresso Peninsular de História Antiga, Faculdade de Letras da Universidade de Coimbra, pp. 468-509.

IDEM, 1994, «Olisiponenses: Epigrafia e Sociedade na Lisboa Romana»e «Lápide», Lisboa Subterrânea, Museu Nacional de Arqueologia, Lisboa, pp. 70-75 e 218.

IDEM, 1996' , «Em torno do Problema da Fundação e Estatuto de Pax Iulia», Arquivo de Beja, Vol.II/III, Série III, pp. 41-62.

IDEM, 1996², «Comércio Marítimo e Sociedade nos Portos Romanos do Tejo e do Vale do Sado", Actas das Primeiras Jornadas sobre Romanização dos estuários do Tejo e do Sado, Publicações Dom Quixote, Lisboa, pp. 343-371.

IDEM, 1997, «As Civitates: Esboço da Geografia Política e Económica do Algarve Romano», Noventa Séculos entre a Serra e o Mar, IPPAR, Lisboa.

MAR, Ricardo, e RUIZ DE ARBULO, Joaquín,1990, «El Foro de Ampurias y las transformaciones augusteas de los foros de la Tarraconense», Actas do Colóquio «Stadtbild und Ideologie» (Outubro de 1987), Bayerischen Akademie der Wissenschaften, Munique, pp. 145-164.

MAR, Ricardo, 1994, «Las Termas y su Inserción Urbana en el Occidente Romano», Actas do XIV Congreso Internacional de Arqueología Clásica, I, Tarragona pp. 285-290.

MARTA, Roberto,1990, Architettura Romana, Edizioni Kappa, Roma.

IDEM, 1991, Tecnicas Costruttiva Romana, Edizioni Kappa, Roma.

MARTÍN-BUENO, Manuel, 1987, «El foro de Bilbilis (Calatayud, Zaragoza)», Los 
Foros Romanos de las Provincias Occidentales, Ministerio de Cultura, Madrid, pp. 99-111.

IDEM, 1990, «Bilbilis», Actas do Colóquio «Stadtbild und Ideologie» (Outubro de 1987), Bayerischen Akademie der Wissenschaften, Munique, pp. 219-240.

MASCARENHAS, J. Fernandes, 1978, «Alguns Subsídios Arqueológicos sobre a Antiga Cidade de Balsa», Por Terras do Algarve.

MATOS, José Luis, 1995, Inventário do Museu Nacional de Arqueologia - Colecção de Escultura Romana, Instituto Português de Museus, Lisboa.

NIELSEN, Inge, 1990, Thermae et Balnea, (I e II), Aarhus University, Aarhus.

NOLEN, Jeannette Smit, 1976-77, «Alguns fragmentos de "paredes fines" de Miróbriga», Setúbal Arqueológica, II-III, pp .432-454.

IDEM, 1985, Cerâmica Comum de Necrópoles do Alto Alentejo, Fundação da Casa de Bragança, Lisboa.

NUNES, Maria Luisa Abreu, 1972, «Moedas romanas de Miróbriga», Actas das II Jornadas Arqueológicas, pp. 185-193.

OLIVEIRA, Francisco de, 1993, «A Imagem da Hispânia em Plínio-o-Antigo», Actas do II Congresso Peninsular de História Antiga, Faculdade de Letras da Universidade de Coimbra, pp. 97-109.

OLIVEIRA, Jorge et alii, 1996, "Cidade de Ammaia - Marvão", Ibn Maruan, nº 6, Câmara Municipal de Marvão, pp. 15-22.

OLIVEIRA, Tomás e Vitor, «Síntese da Geologia da Faixa Piritosa, em Portugal, e das Principais Minerações Associadas», Mineração no Baixo Alentejo, Câmara Municipal de Castro Verde, pp. 8-27.

PALOL, Pedro de, 1987, «El Foro Romano de Clunia», Los Foros Romanos de las Provincias Occidentales, Ministério de Cultura, Madrid, pp. 153-163.

IDEM, 1989-90, «Los Edificios de Culto en la Ciudad de Clunia», Anas, 2-3, Mérida, pp. 37-56.

PASTOR MUÑOZ, Mauricio e PACHÓN ROMERO, Juan-Antonio, 1991, «Excavación Arqueológica en Miróbriga: Campañas de 1987/88», Extremadura Arqueológica II, Mérida-Cáceres, pp. 347-360.

PASTOR MUÑOZ, Mauricio et alii, 1992, Excavaciones Arqueológicas en el " $\mathrm{Ce}$ rro del Cabezo", Capilla, Badajoz. Campañas de 1987/88. Editora Regional de Extrmadura, Mérida. 
PASTOR MUÑOZ, 1993, «Mirobriga Turdulorum: Sintesis Historico-Arqueológica», Actas do II Congresso Peninsular de História Antiga, Faculdade de Letras da Universidade de Coimbra, pp. 597-621.

PASTOR MUÑOZ, Mauricio et alii, 1992, Excavaciones Arqueológicas en el "Cerro del Cabezo", Capilla, Badajoz. Campañas de 1987/88. Editora Regional de Extrmadura, Mérida.

PEDRERO, Rosa, 1996, "El Hidrónimo Prerromano Mira", Emerita, Tomo LXIV, fasc. $2^{\circ}$, Madrid.

PEREIRA, Isabel, 1997, «O Museu e a colecção de Moedas: Santiago do Cacém», Pelo Caminho das Pedras, Museu Municipal de Santiago do Cacém.

PEREIRA, Maria Adelaide Garcia, 1971, «Subsídio para o Estudo da Terra Sigillata de Miróbriga», Actas do II Congresso Nacional de Arqueologia, Coimbra, pp. 433-444.

PERRAULT, Claude, Compendio de los Diez Libros de Arquitectura de Vitruvio, (tradução fac-simililada de Don Joseph Castañeda de 1761), Comisión de Cultura del Colegio Oficial de Aparejadores y Arquitectos Técnicos, Murcia, 1981.

IDEM, 1984, «La Religion Romaine en Milieu Provincial» (ed. ch. - M. Ternes), Bulletin des Antiquités Luxembourgeoises, 15, pp. 75-126.

PINA POLO, Francisco, 1993, «Existió una política romana de urbanización en el Nordeste de la Península Ibérica?», Habis, 24, Universidad de Sevilla, pp. 77-94.

PIETE,J., 1994: «Urbanización y Romanización en el Nordeste de la Península Ibérica», Actas do XIV Congreso Internacional de Arqueología Clásica, II, Tarragona, pp. 329-331.

PONSICH, Michel, 1970, «Volubilis in Morokko», Antique Welt 2.

PONSICH, Michel, 1990, «Volubilis Origen de la Historia de Marruecos», Revista de Arqueologia, $\mathrm{n}^{\circ}$ 112, Zugarto Ediciones, Madrid, pp. 34-44.

PONTE, Salete da, 1979, «As Fíbulas de Miróbriga», Setúbal Arqueológica, vol., II, Setúbal, pp. 195-204.

IDEM, 1989: Sellium, Centro de Estudos de Arte e Arqueologia da E.S.T.T., Tomar. IDEM, 1990, «Volubilis, Origen de la Historia de Marruecos», Revista de Arqueologia, $\mathrm{n}^{\circ} 112$, Zugarto Ediciones, Madrid, pp. 34-44.

QUARESMA, António Martins, 1986, Apontamento Histórico sobre Vila Nova de Milfontes, Vila Nova de Milfontes. 
QUARESMA, José Carlos, s/d, As Terra Sigillata Foceense Tardia e Africana de Miróbriga, Castelo Velho de Santiago do Cacém (inédito).

RESENDE, André de, 1593, De Antiquitatibus Lusitaniae, Lib.IV, Évora.

RIBEIRO, José Cardim, 1982-83, «Estudos histórico-epigráficos em torno da figura de L. Iulius Maelo Caudicus», Sintria I-II (tomo 1), Câmara Municipal de Sintra, pp. $151-476$ (v.p.175)

RIBEIRO, José Cardim, 1983, «Contributos para o conhecimento e devoções de cultos e devoções de cariz aquático relativos ao território do Município Olissiponense», Boletim Cultural da Assembleia Distrital de Lisboa, 89 (1), pp. 331-369.

IDEM, 1994 ${ }^{1}$, «FELICITAS IVLIA OLISIPO - Algumas Considerações em torno do catálogo Lisboa Subterrânea», Al-Madan, II Série, n 3, Almada, pp. 75-95.

IDEM, $1994^{2}$, «Breve Nota acerca do Criptopórtico de Olisipo e possível localização do Forum Corporativo», Actas do Encontro de Arqueologia Urbana, Bracara Augusta, Vol. XLV, Braga, pp. 191-195.

RODÀ, Isabel, 1994, «Los Materiales de Construcción en Hispania», Actas do XIV Congreso Internacional de Arqueología Clásica, I, Tarragona, pp. 323-334.

RODRÍGUEZ DIAZ, Alonso, 1995, «Territorios y Etnias Prerromanas en el Guadiana Medio: Aproximación Arqueológica a la Beturia Túrdula», Celtas y Turdulos: la Beturia, Museu Nacional de Arte Romano, Mérida, pp. 205-254.

RODRÍGUEZ OLIVA, Pedro, 1993, «Transformaciones Urbanas en las Ciudades de la Baetica durante el Alto Imperio», Actas do XIV Congreso Internacional de Arqueologia Clásica, I, Tarragona, pp. 347-356.

ROLDÁN GÓMEZ, Lourdes, 1987, «Técnica Edilicia en Itálica. Los Edificios Públicos». AEspA, 60. pp. 89-122.

IDEM, 1987², «La Técnica Edilicia Romana y su Empleo en Hispania», I e II, Revista de Arqueologia, $\mathrm{n}^{\circ}$ s 78 e 79, Madrid, pp. 29-37 e 49-55.

IDEM, 1988, «El Opus testaceum en Itálica. Edificios Privados». AEspA, 61.119-140. . ROTH CONGÈS, Anne, 1987, «L'hypothèse d'une basilique à deux nefs à Conimbriga et les transformations du forum», Mélanges de l'Ècole Française de Rome. Antiquité, 99, pp. 711-751.

IDEM, 1994, «Le Sanctuaire et le Centre Monumental de Glanum (Saint-Remy-deProvence) du IIè S. avant au IIIè S. apres J.-C.», Actas do XIV Congreso Internacional de Arqueología Clásica, II, Tarragona, pp. 376-378. 
RUBIO FUENTES, Maria José, 1993, «Caesarobriga, Ciudad Romana de la Lusitania», Actas do II Congresso de História Antiga, Faculdade de Letras da Universidade de Coimbra, pp. 567-580.

SÁNCHEZ-PALENCIA, F. Javier et alii, 1997, «Circo Romano de Mérida», Mérida - Excavaciones Arqueológicas (1994-1995), Consorcio Ciudad Monumental Histórico-Artística y Arqueológica de Mérida, Mérida. pp. 245-253.

IDEM e SAINZ PASCUAL, Maria Jesus, 1988, El Circo Romano de Toledo, Estudios Y Monografias, $n^{\circ}$, Consejeria de Educación y Cultura, Toledo.

SANMARTÍ I GREGO, Enric et alii, 1990, «Emporion: Un ejemplo de monumentalización precoz en la Hispania republicana (Los santuarios helenísticos de su sector meridional)», 117-144. "Stadtbild und Ideologie», (Outubro de 1987), Bayerichen Akademie der Wissenschaften, Munique.

SILVA, Armando Coelho Ferreira da, 1995, «Portuguese Castros: The Evolution of the Habitat and the Proto-Urbanization Process», Social Complexity and the Development of Towns in Iberia (From the Copper Age to the Second Century AC), ed. Barry Cunliffe \& Simon Keay, Oxford University Press, pp. 263-289.

SILVA, Carlos Tavares da; SOARES, Joaquina e SANTOS, Manuel Farinha dos, 1973, «Moedas hispânicas do Povoado do Pedrão, Setúbal», Actas das II Jornadas Arqueológicas, Associação dos Arqueólogos Portugueses, Lisboa, 1, pp. 307-318.

SILVA, Carlos Tavares da; SOARES, Joaquina, 1979, «Cerâmica Pré-romana de Miróbriga», Santiago do Cacém, Setúbal Arqueológica, Vol. V, II, Setúbal, pp. 159-184.

SILVA, Carlos Tavares da, 1982, «Santiago do Cacém. Pedra da Atalaia Idade do Ferro (séculos III-I a.C.) e Época Romana (século I d.C.)", Informação Arqueológi$c a, 2$, IPPC, Lisboa, p. 26

SILVA, João Cruz e, 1944, 1945 e 1946, «Apontamentos e Considerações sobre as Pesquisas Arqueológicas realizadas desde 1922 nos Concelhos de S.Tiago-de-Cacém, Sines e Odemira», Arquivo de Beja, I: 226-231; II: 291-299 e III: 336-351.

IDEM, «Concelho de S. Tiago de Cacem», Noticia Histórica, Baixo Alentejo, p. 1065. SINTES, Claude, 1996, «La Gestion du Sous-sol Archeologique», Ciudades Modernas Superpuestas a las Antiguas, Mérida (Jul.1996). Resumo da comunicação, pp.1-17.

SOUZA, Vasco de, 1990, Corpus Signorum Imperii Romani, Coimbra.

STYLOW, Armin, 1990, «Apuntes sobre el Urbanismo de la Corduba romana», Actas do Colóquio «Stadtbild und Ideologie», (Outubro de 1987), Bayerischen Akademie der Wissenschaften, Munique, pp. 259-282. 
TORREGO SALCEDO, Espezanza, 1988, Textos de Historia del Arte, La Balsa de la Medusa, Madrid.

TRANOY, Alain, "Communautés Indigénes et Promotion Juridique», Ciudad y Comunidad Cívica en Hispania (Siglos II y III d. C.), 1993, Casa de Velázquez, Madrid, pp. 27-35.

VASCONCELOS, José Leite de, 1905, Religiões da Lusitânia, I, II, III, Imprensa Nacional- Casa da Moeda, Lisboa.

VASCONCELOS, José Leite de, 1914, «Excursão Arqueológica à Extremadura Transtagana», O Archeologo Português, Vol.XIX, Imprensa Nacional, Lisboa.

VAZQUEZ Y HOYS, A. Mª 1982 , «Consideraciones Estadisticas sobre la Religión Romana en Hispania», La Religión Romana en Hispania, Ministerio de Cultura, Madrid, pp. 167-176.

VIANA, Abel, 1946, «A Arqueologia do Baixo Alentejo na Obra do Bispo Pacense, D. Frei Manuel do Cenáculo Vilas-Boas», Arquivo de Beja, III, 1-2, Beja.

VILHENA, A., 1938, Roteiro da Vila de S. Tiago de Cacém, Lisboa.

VITRÚVIO, Ed. 1909, Sur L'Architecture, (Texto e Traduçăo de Auguste Choisy), Imprimerie-Librerie Lahure, Paris

WARREN, Herbert Langford (org), 1960, I The Ten Books of Architecture, (trad. Morris Hicky Morgan), Dover Publications, New York.

YEGÜL, Fikret, 1995, Baths and Bathing in Classical Antiquity, The MIT Press, Nova Iorque.

ZANKER, P., 1972, Il Foro Romano. La sistematizione da Augusto alla tarda antichitá, Roma. 


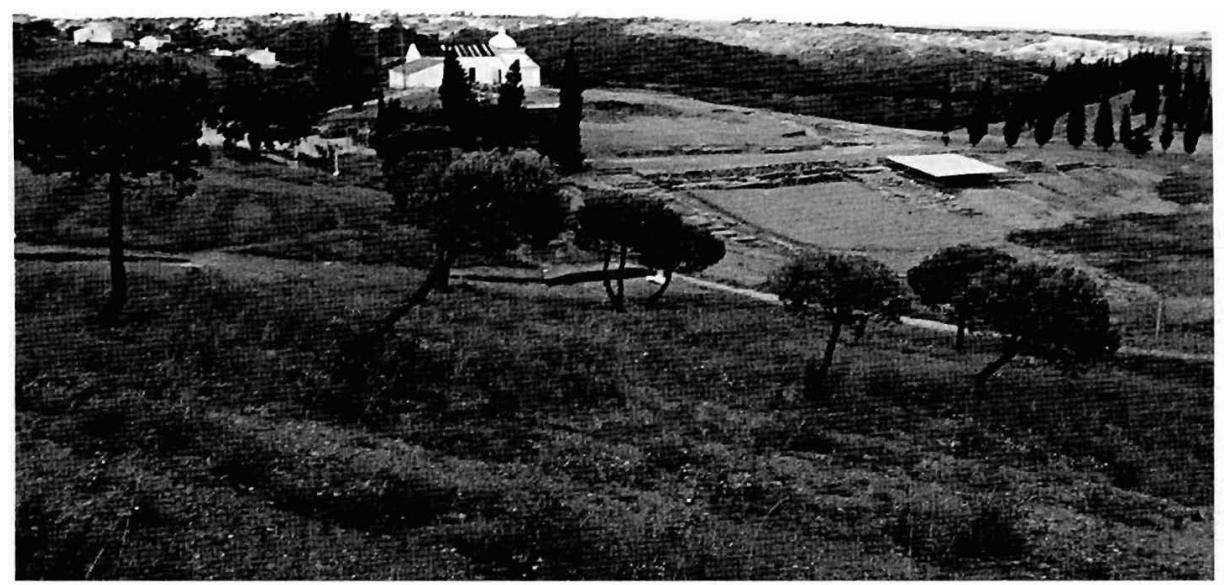

Lámina 1: Vista geral da actual zona de entrada de Miróbriga. Ao fundo são visíveis as obras de recuperaçăo da Capela de $\mathrm{S}$. Brás.

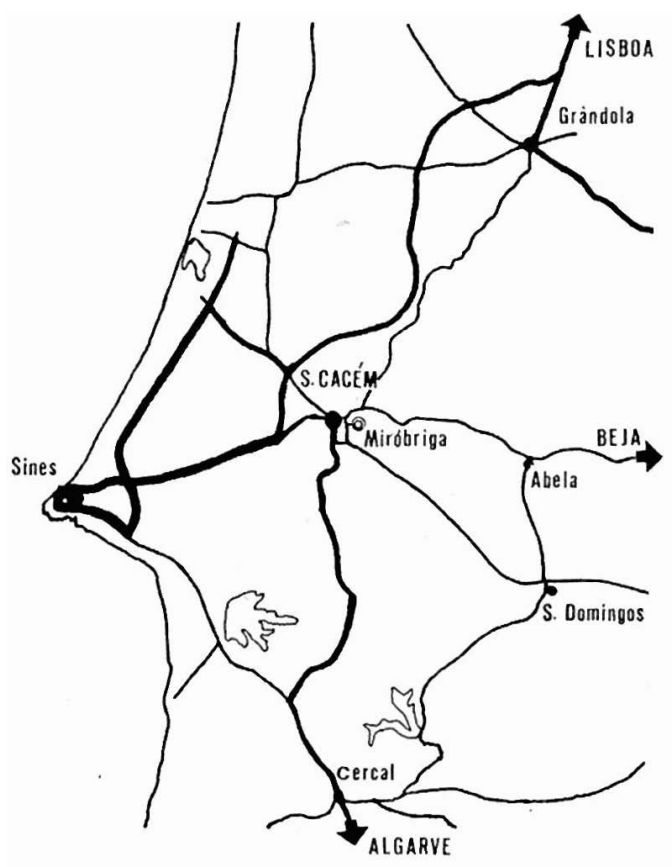

Lám. 2: Localização de Miróbriga 


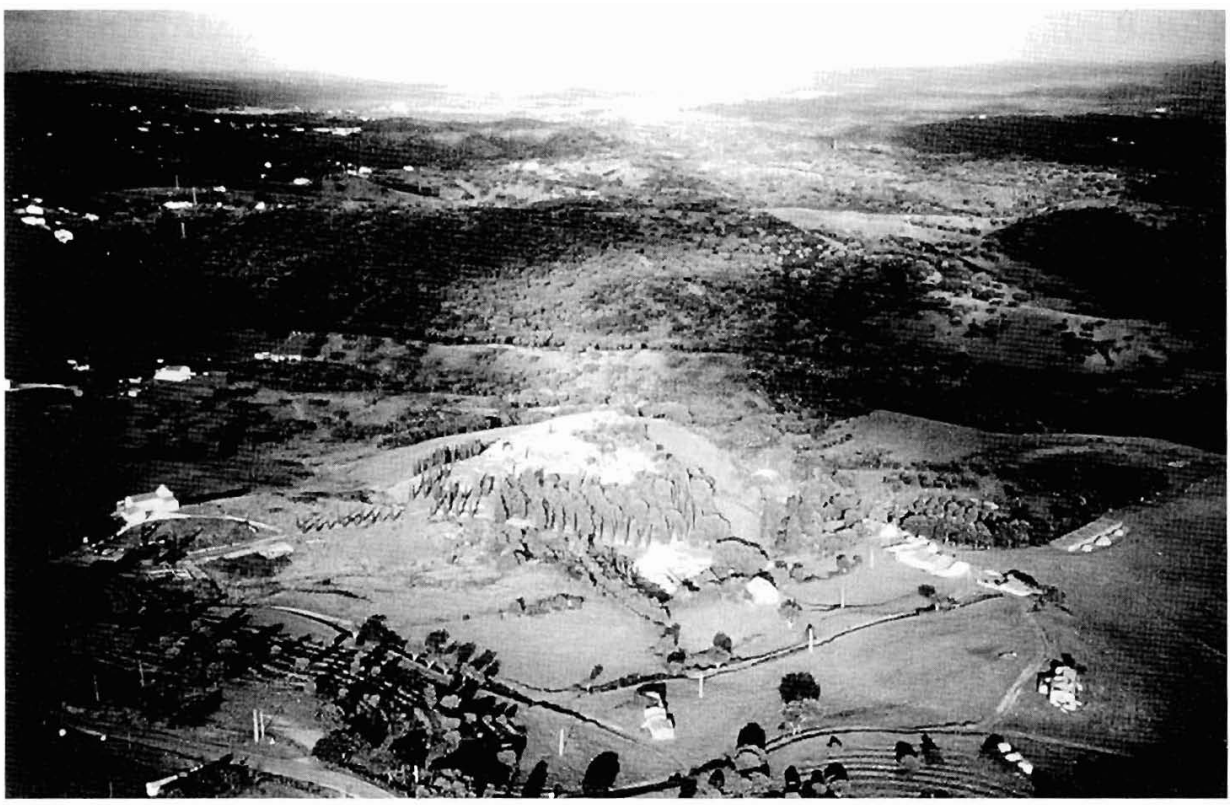

Lámina 3: Fotografía aérea de Miróbriga e envolvente (1994)

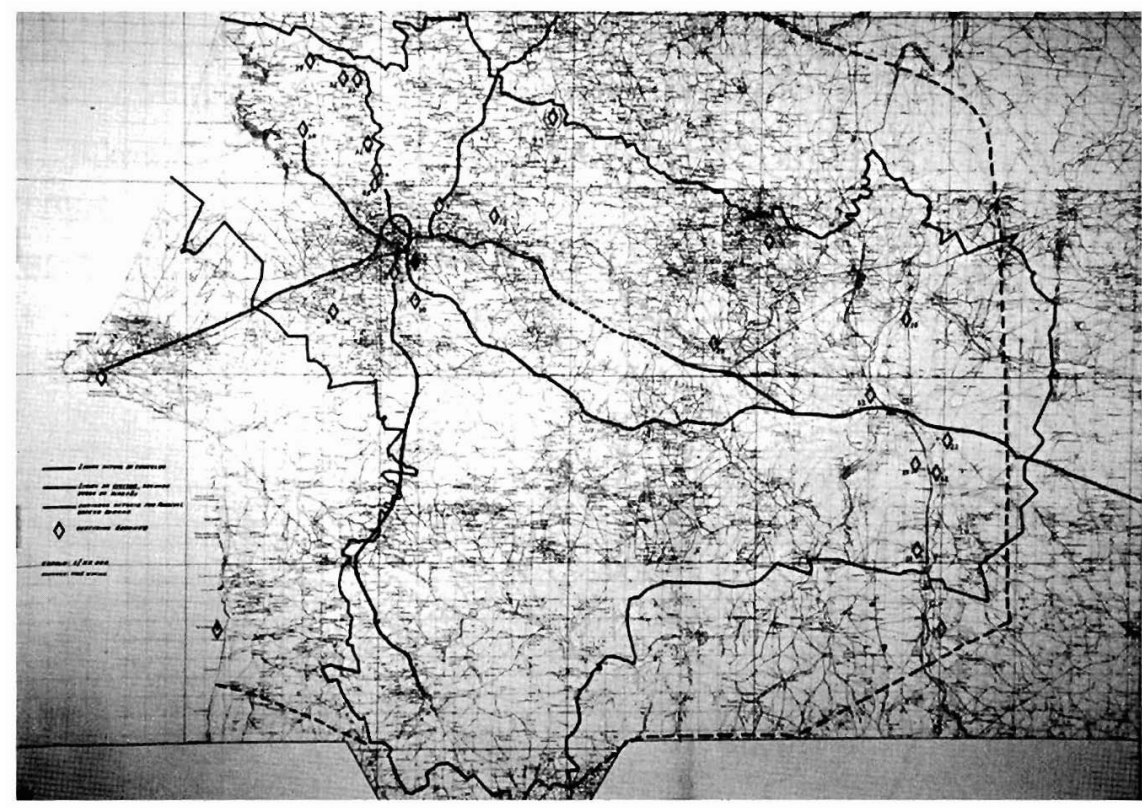

Lámina 4: Território de Miróbriga e hipotética rede viária. 


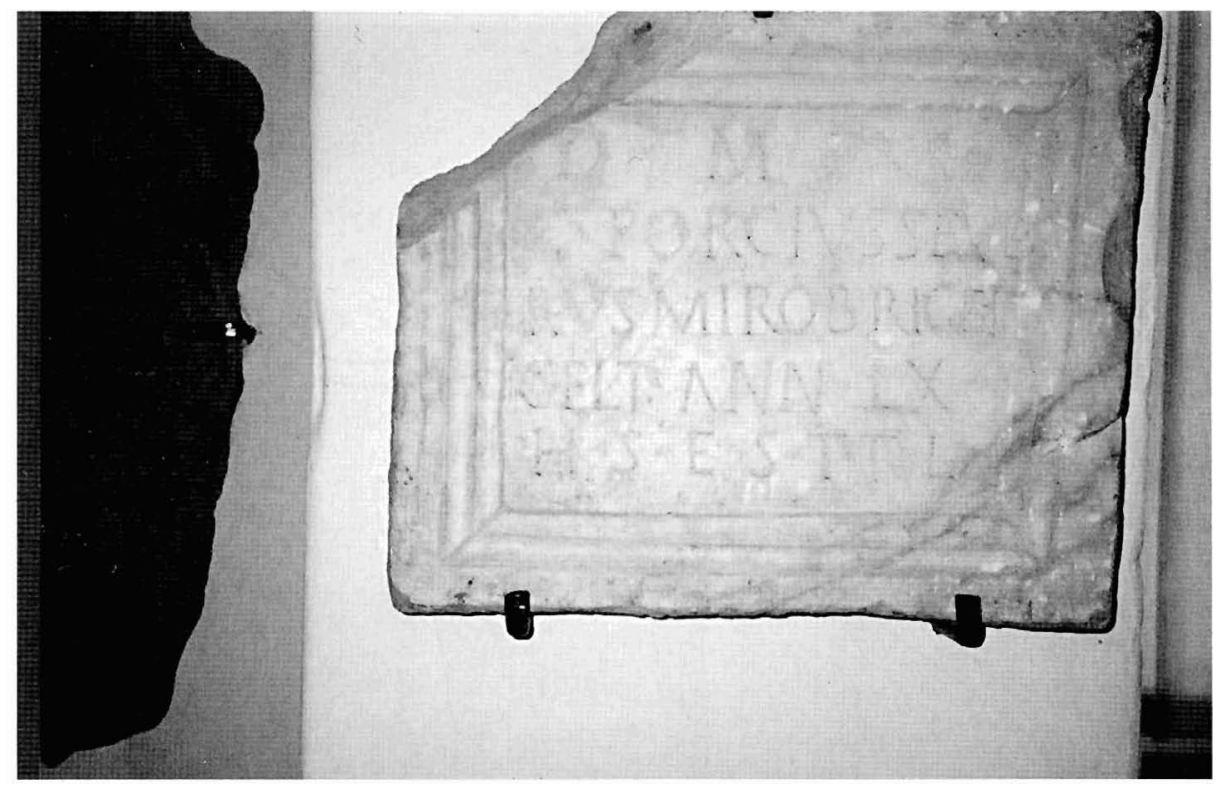

Lámina 5: Inscriçāo proveniente da Herdade do Francisquinho. Museu Municipal de Santiago do Cacém.
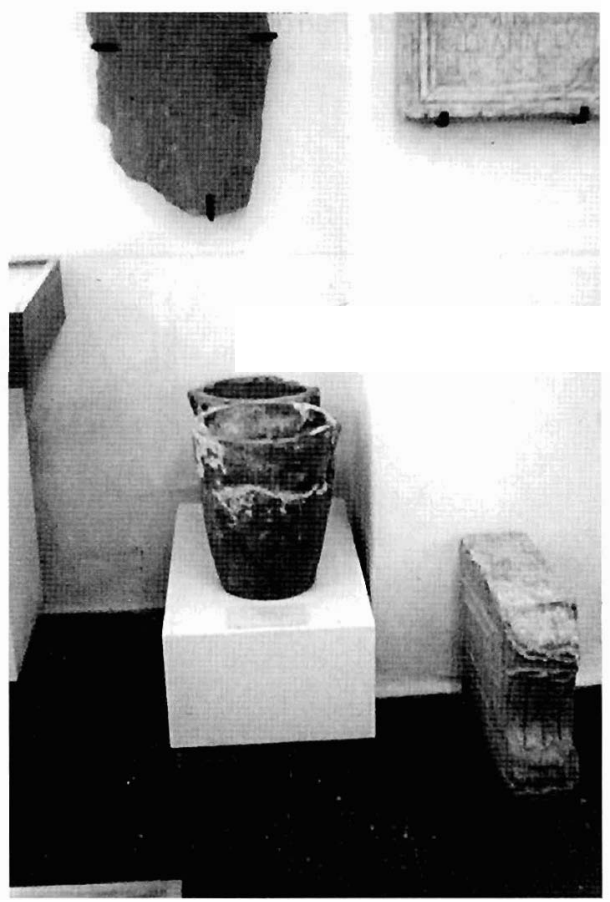

Lámina 6: Cadinhos metalúrgicos. Museu Municipal de Santiago do Cacém. 
MARÍA FILOMENA SANTOS BARATA

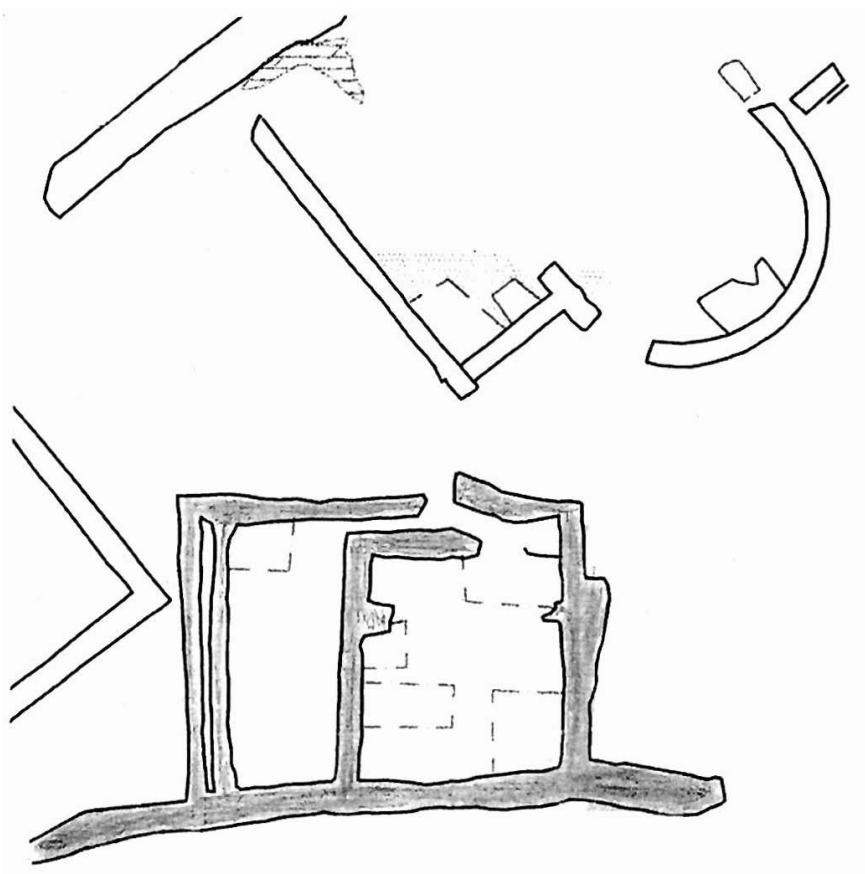

Lámina 7: Estruturas do designado «Templo da Idade do Ferro»

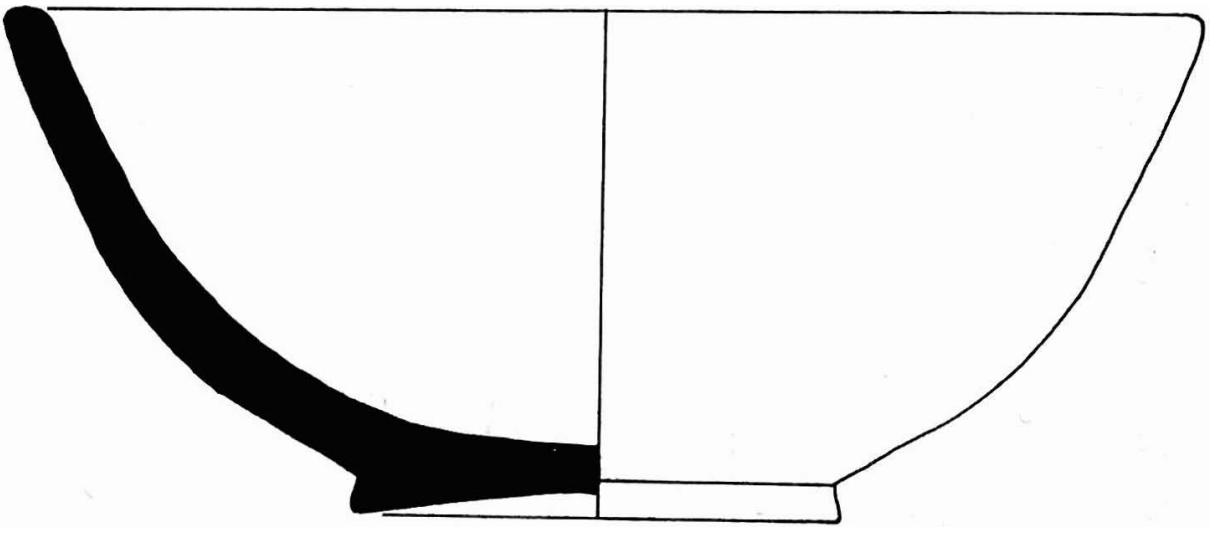

Lám . 8: Tigela ou patella invertida que continha no seu interior ossos de frango.

124

--- Grupo de investigación P.A.I. HUM 236 | http://www.arqueocordoba.com/publ/anales.htm --- 


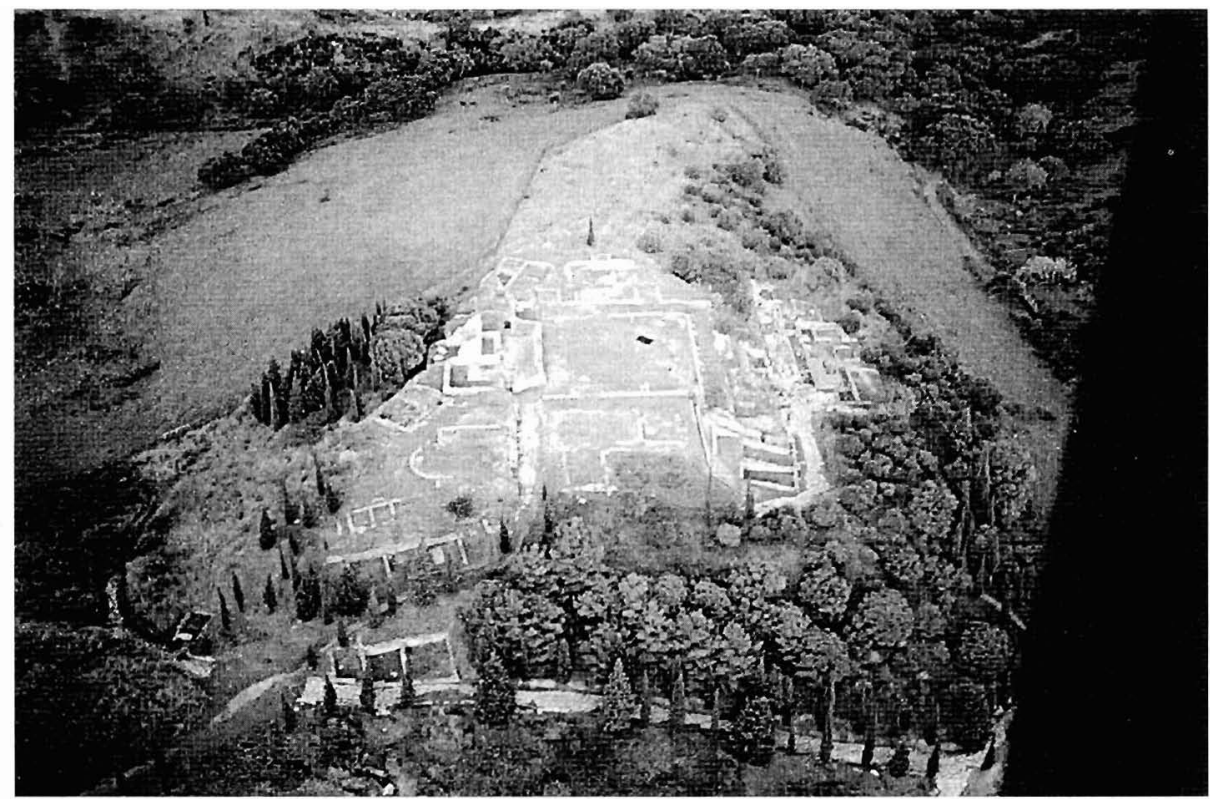

Lámina 9: Fotografía aérea do Forum de Miróbriga.

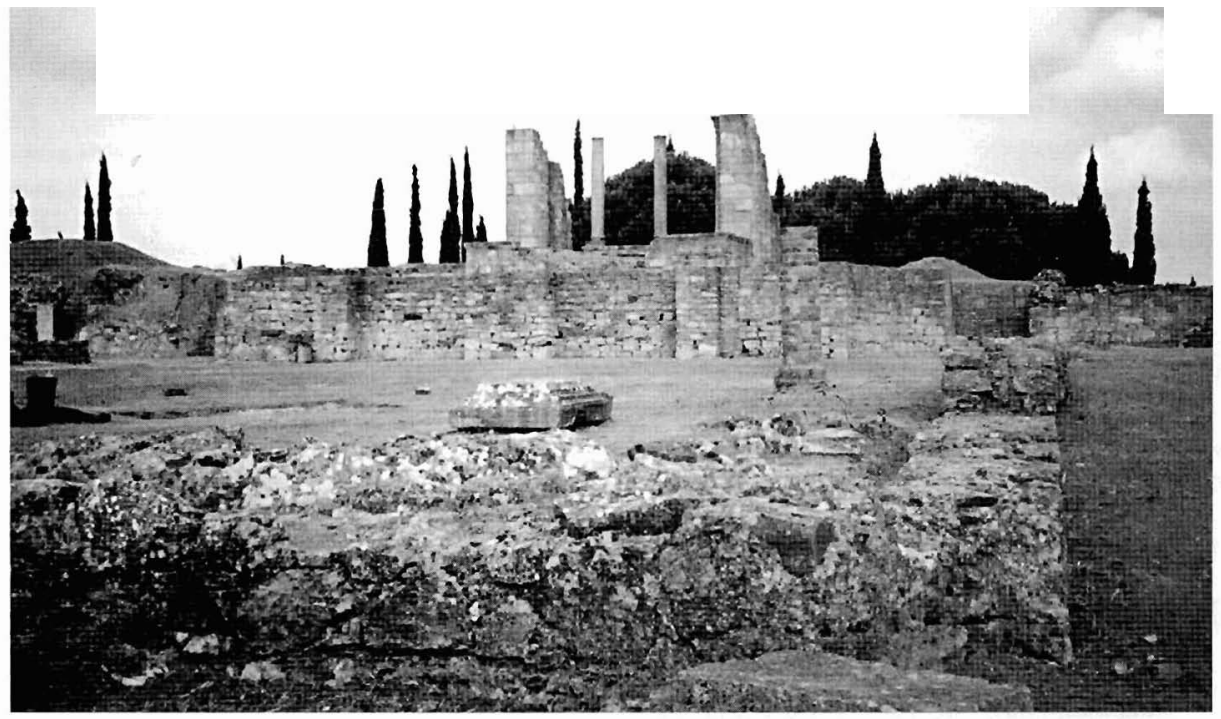

Lámina 10: Aspecto geral do Forum com o templo centralizado. 


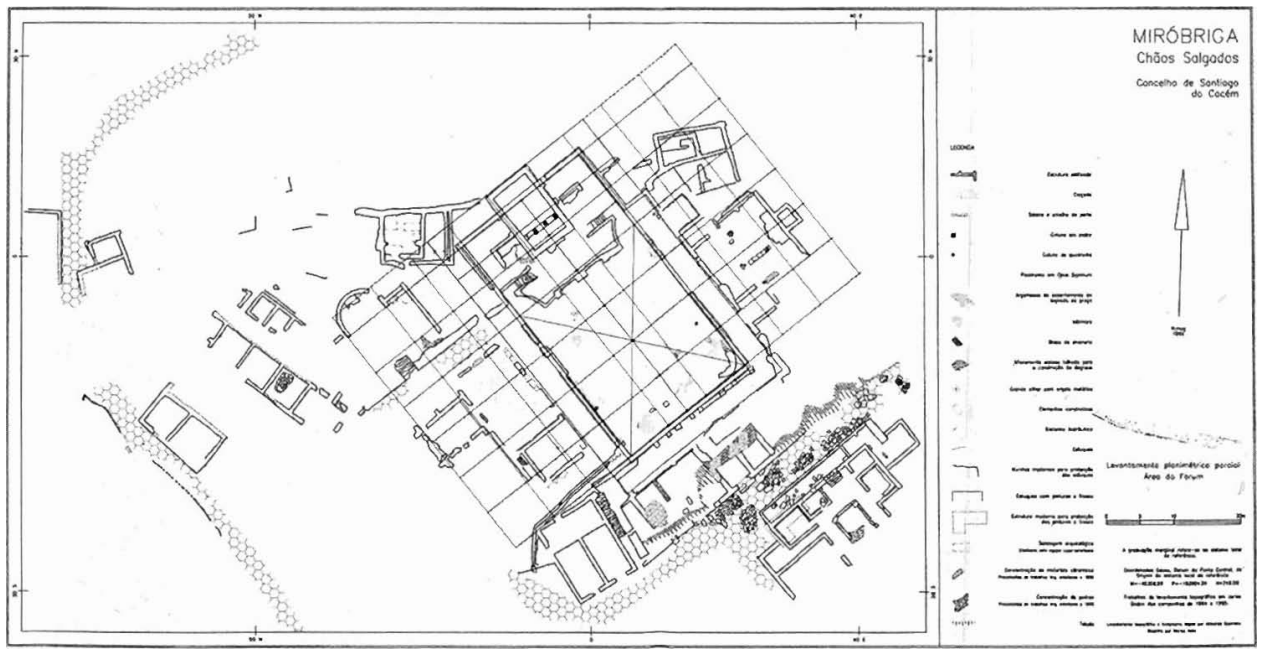

Lám. 11: Tentativa de interpretação da metrologia do Forum. Levantamento topográfico de pormenor de Armendo Guerreiro.

Lámina 12: Escadas dde acesso ao Forum pe la zona das Tabernae que se desenvolvem do lado sul.

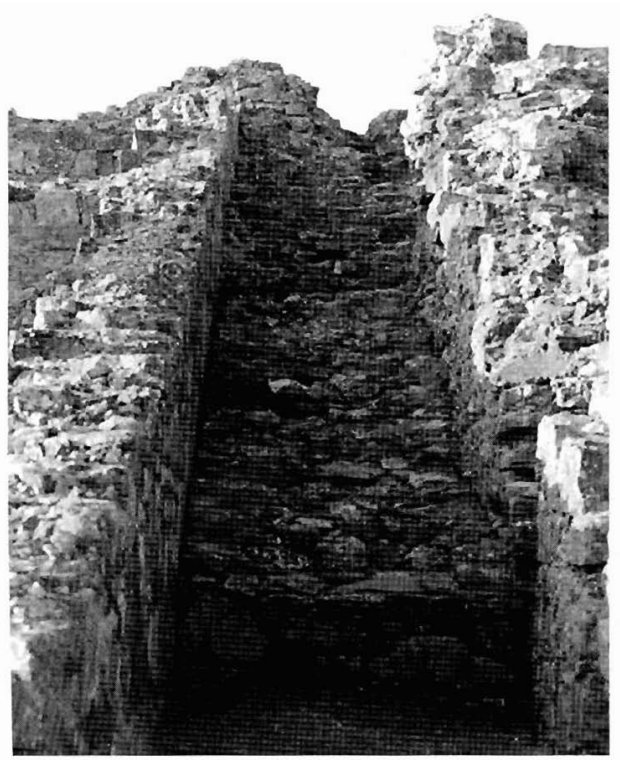

--- Grupo de investigación P.A.I. HUM 236 | http://www.arqueocordoba.com/publ/anales.htm --- 


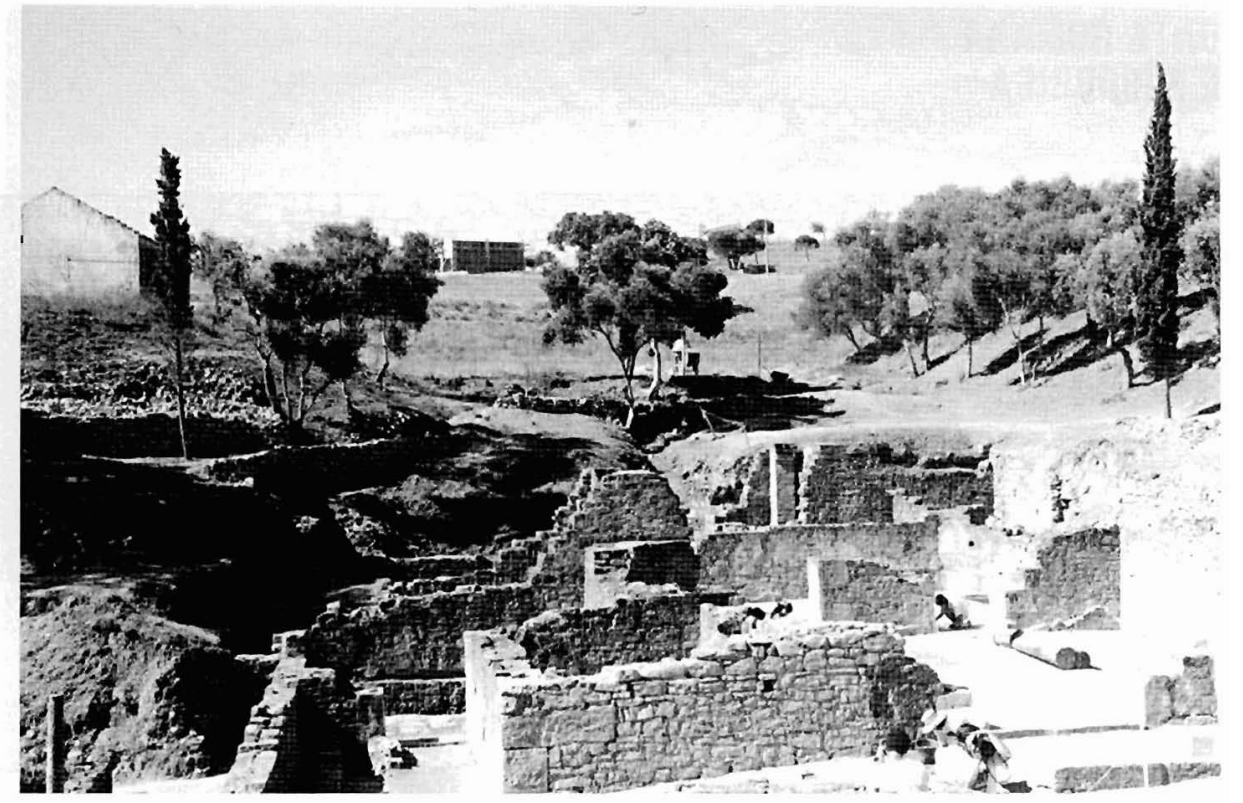

Lámina 13: Balnea de Miróbriga.

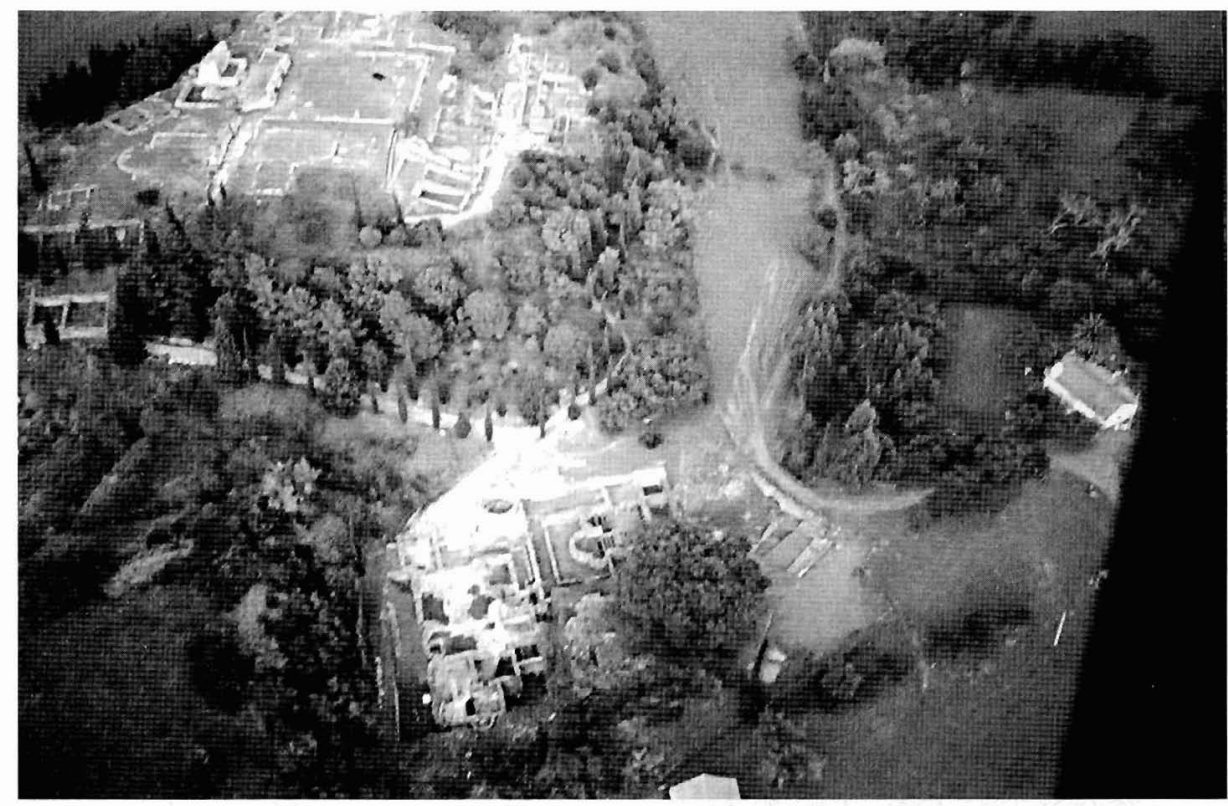

Lámina 14: Balnea e Forum de Miróbriga. 


\section{PONTE ROMANA DE MIRÓBRIGA}

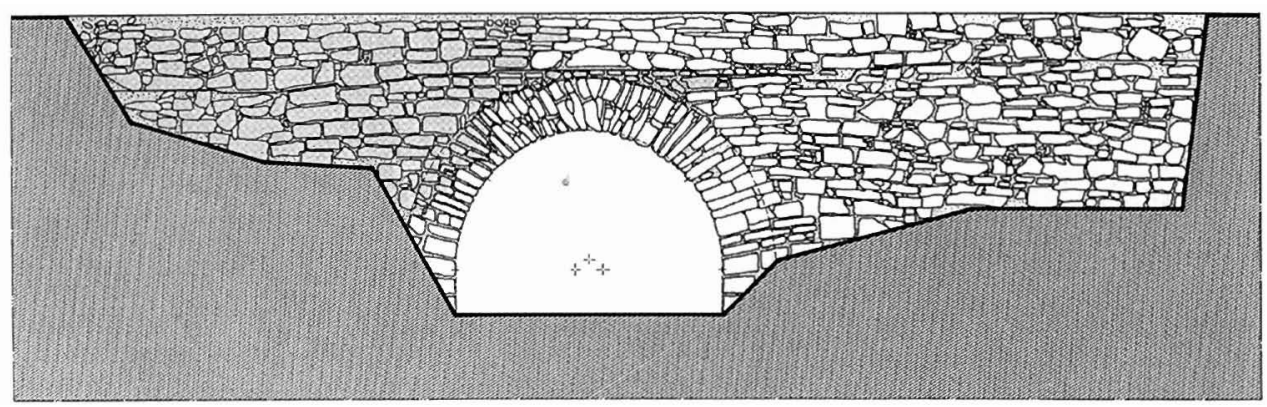

\section{ALCCADO POENTE}

Desenho-Jori Maties

Sentiogo do Cocén 1

Colsboracōo - Mocic toōo Gamito

Escole Secuncória de Sentioge de Cacém)

Nouembero ot 1992

Lám. 15.

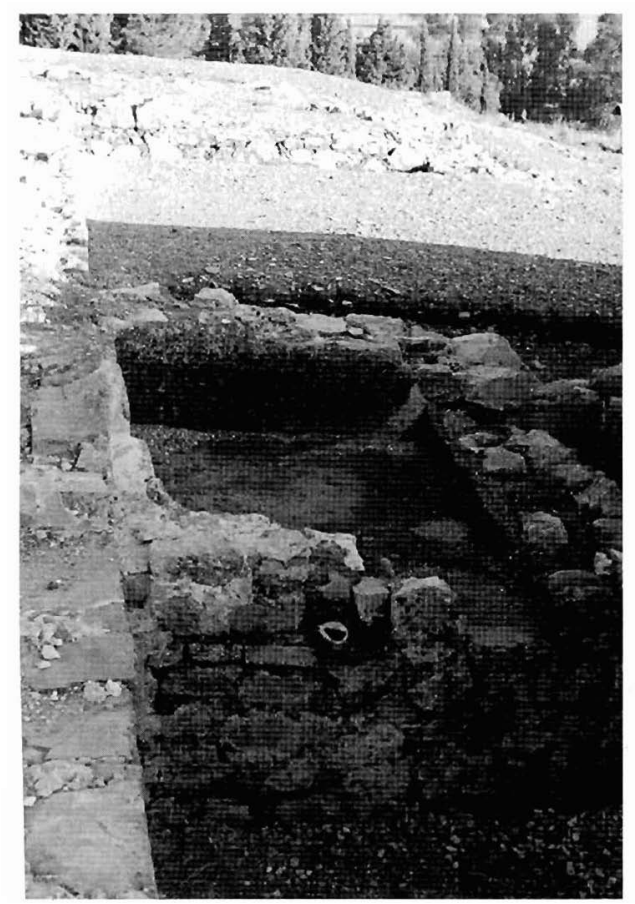

Lámina 16: Canalização de chumbo no interior de uma habitação. 


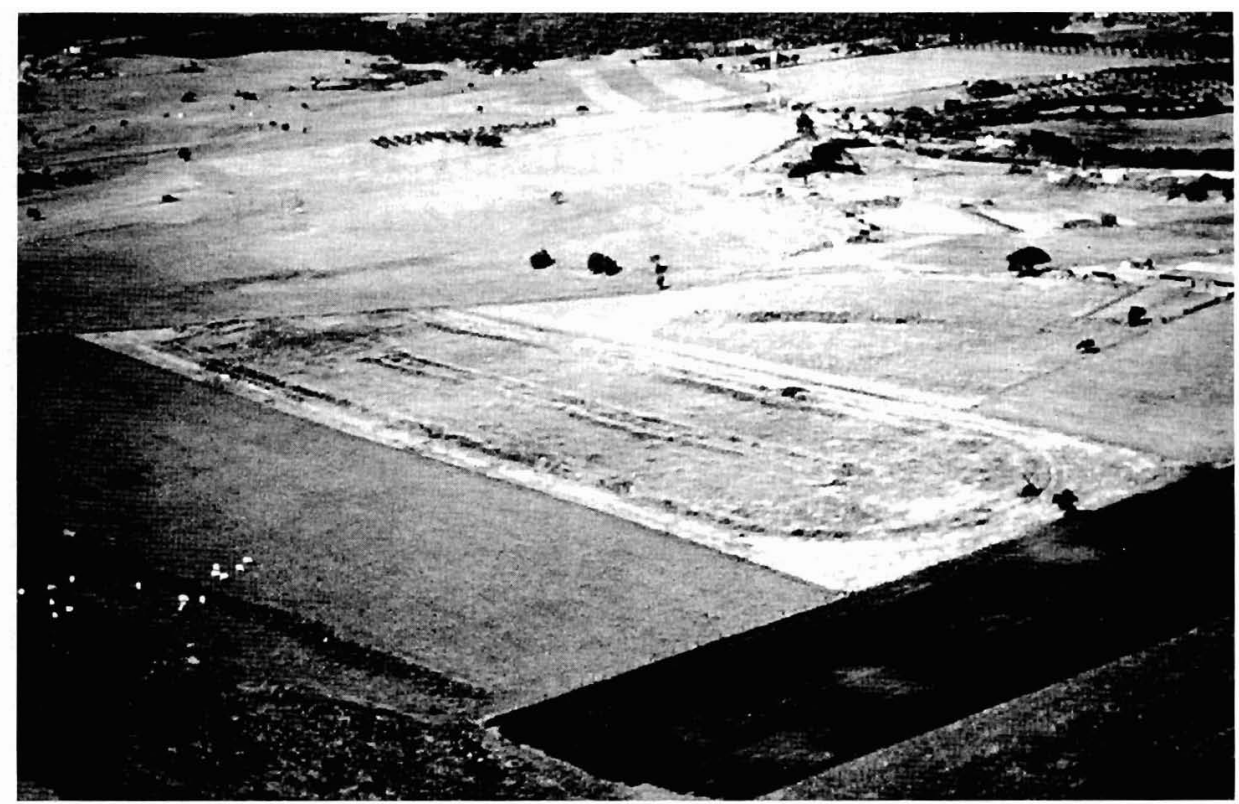

Lámina 17: Hipódromo de Miróbriga. 